UnIVERSIDAD NACIONAL DE LA PLATA

FACULTAD DE HUMANIDADES Y CIENCIAS DE LA EdUCACIÓN SECRETARÍa de Posgrado

\title{
EL SECRETO EN LAS DEMOCRACIAS CONTEMPORÁNEAS. EL CASO DE LA ARGENTINA
}

El debate parlamentario sobre la publicidad de los actos de gobierno y la derogación de las leyes secretas.

Abogado Carlos Alberto VALLEFín

Tesis para optar por el grado de Magíster en Ciencias Sociales

Director Doctor Osvaldo BARRENECHE, UNLP

La Plata, febrero de 2017 


\section{AGRADECIMIENTOS}

No muchos años atrás, la Facultad de Humanidades y Ciencias de la Educación y la Facultad de Ciencias Jurídicas y Sociales de la Universidad Nacional de La Plata compartían el mismo edificio. Bastaba atravesar una puerta para abandonar una e ingresar a la otra. Durante mucho tiempo practiqué esa rutina que parecía obligarme a transitar mundos gobernados por disciplinas distantes. Pese a su nombre oficial, de un lado estaba la Facultad de Derecho y de otro, la de Humanidades. Era comprensible apocopar el de ésta para evitar el largo "y Ciencias de la Educación" pero lo era menos, cambiar lisa y llanamente el nombre de aquélla. En su denominación oficial no figura la palabra derecho pero en la percepción general eso era lo que se enseñaba allí. En algún momento advertí que esa mutilación en el lenguaje también llegaba a los contenidos y, por eso, tras alcanzar el título de abogado, emprendí el recorrido por la carrera de Letras que dejé inconclusa.

Mucho tiempo después -tanto que en medio hubo un matrimonio, hijas, alegrías enormes y penas infinitas- retorné a los estudios sociales a través del Doctorado y Maestría en Ciencias Sociales que ofrece la Facultad de Humanidades y Ciencias de la Educación. La decisión fue un proceso individual. En realidad nunca quise dejar Humanidades. En realidad siempre pensé que el mundo del derecho -en el que llevo ya tres décadasestaba disminuido sin aquéllas. Pero llevar a la práctica esa decisión fue un proceso colectivo. La colaboración y comprensión de mi esposa Alejandra y de mis hijas Helena y Laura ha sido imprescindible. Muchas veces he pensado en mis recorridos académicos y cuando lo hago, dudo en agradecerles o en pedirles disculpas. Otra fuente de auxilio familiar han sido mis sobrinos Camila, Lucio y Juan Cruz. Ellos también se inclinaron por las ciencias sociales en esta misma Facultad y, a su modo, me impulsaron en este recorrido.

Francisco VÉRTIZ me orientó en infinidad de ocasiones para poder cumplir adecuadamente con las exigencias de los cursos. Agustín CASAGRANDE compartió su experiencia y fue el responsable de poner fin a una angustiosa búsqueda: la de un director de tesis.

Fue así que me comuniqué con el doctor Osvaldo BARRENECHE. Tuvo la gentileza de aceptar el cargo y de ayudarme en todo el proceso de redacción. Me hizo sugerencias que abrieron nuevas visiones sobre el tema de la investigación y leyó y corrigió con detalle cada avance del escrito. Si tuviera que decirlo acudiendo a la teoría jurídica, diría que se trata de un partícipe necesario pues sin su auxilio o cooperación el hecho -en este caso, la tesis- no habría podido concretarse. Los errores que subsistan -claro está- son mi de exclusiva responsabilidad.

A todos les estoy muy agradecido. 


\section{RESUMEN \\ PALABRAS CLAVE}

\section{Democracia. Publicidad actos de gobierno. LeYes SeCretas.}

El secreto estatal constituye uno de los problemas que aquejan a las democracias contemporáneas. Los actos de gobierno, como regla, están sujetos a publicidad a fin de que la población tome conocimiento de las decisiones estatales. Sin embargo, por distintos motivos, esta regla está sujeta a ciertas excepciones. Algunas procuran proteger derechos o intereses que se consideran superiores. La seguridad nacional o la intimidad de las personas constituyen los típicos ámbitos para impedir la difusión. Otras, en cambio, impiden el acceso en áreas cuya reserva es más opinable y así se evita el indispensable control de la actividad de los funcionarios. Las normas y prácticas que impiden el acceso a la información pública no se concilia con la idea de transparencia que exige la vida de los Estados modernos. De esta opacidad suelen derivarse actos ilegítimos y, en pareja medida, actos de corrupción.

El debate sobre la necesidad y extensión del secreto estatal no es un fenómeno contemporáneo sino que se inscribe en la teoría política clásica. Las leyes de acceso a la información pública que paulatinamente han ido sancionado casi todos los países del globo y los reclamos ciudadanos por la transparencia, han renovado su actualidad. En la Argentina la cuestión tiene matices singulares. No sólo existe actividad secreta por parte del Poder Ejecutivo -práctica extendida en muchos países- sino que durante más de un siglo existieron leyes secretas.

El presente trabajo pretende dar cuenta de las particularidades que tuvo el debate parlamentario que, en el Congreso de la Nación, concluyó en el año 2006 con la sanción de la ley 26.134. Ésta, por un lado, dejó sin efecto el carácter secreto de todas las leyes que fueron sancionados bajo esa condición y, por otro, prohibió el dictado de esa clase de leyes en el futuro. Ese debate se caracterizó por la invocación de las ideas de publicidad asociadas a un sistema republicano pero fueron empleadas, por ciertos legisladores, para votar a favor de la ley y otros en contra. Se parte de la hipótesis de que los primeros utilizan concepciones débiles o restringidas de la publicidad que demanda la vida democrática y de que la ley sancionada constituye una contribución estrecha a la transparencia.

Para abordar la investigación se precisó el número de leyes secretas sancionadas entre 1891 y 2006, su contenido y el contexto histórico en el que se dictaron. Se examinaron los discursos de diputados y senadores y se caracterizaron algunas ideas respecto de la democracia y su vinculación con la publicidad de los actos de gobierno. Desde esa perspectiva, se discutió cuanto secreto es tolerable o cuanta publicidad es necesaria para satisfacer los requerimientos democráticos. La hipótesis es que la sanción de la ley examinada constituyó una débil contribución a la transparencia en el país. 


\section{ÍNDICE}

INTRODUCCIÓN ........................................................................................... 6

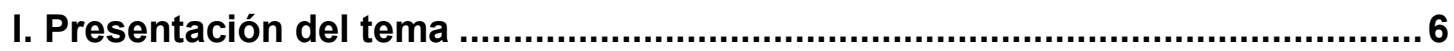

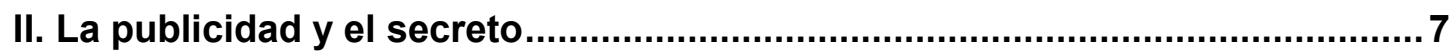

III. El planteo del problema: un debate, muchas ideas .....................................12

IV. El estado de la cuestión y el marco teórico ............................................... 144

V. Fuentes y consideraciones metodológicas ................................................211

VI. Estructura del trabajo .......................................................................... 233

CAPÍTULO I: La publicidad y el secreto en el pensamiento político..................... 26

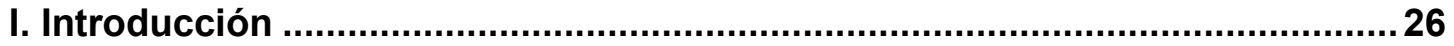

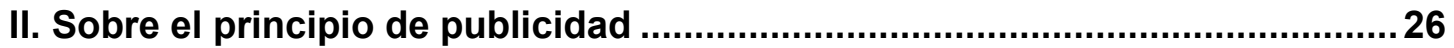

III. Publicidad y secreto: un paseo por la filosofía política.................................29

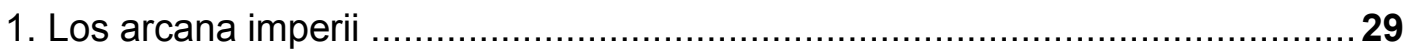

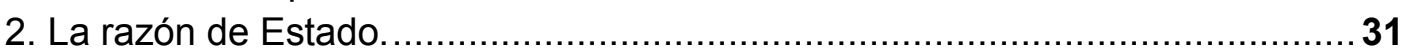

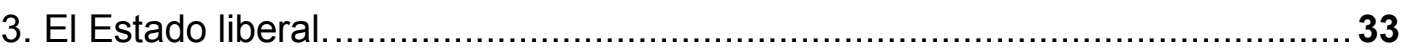

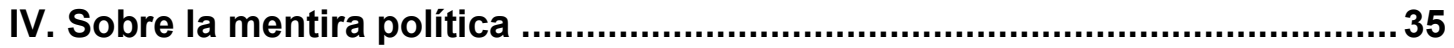

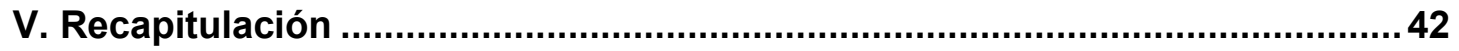

CAPÍTULO II: El secreto de Estado en la democracia contemporánea...................44

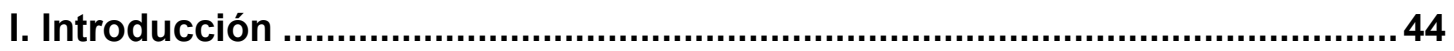

II. El secreto y la publicidad: una cuestión de límites ...................................511

1. La sociología de la mentira y del secreto. ..................................................52

2. El secreto en la vida democrática. ..............................................................55

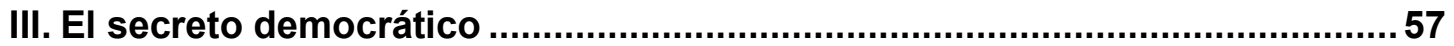

1. Sobre los conceptos de democracia. ..................................................... 588

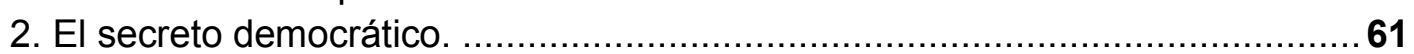

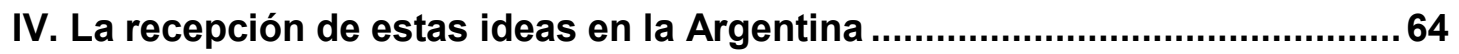

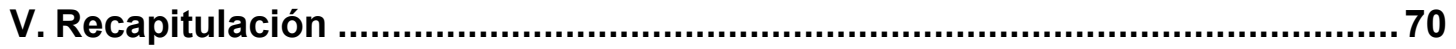

CAPÍTULO III: Las leyes secretas: contenido y momento histórico de la sanción

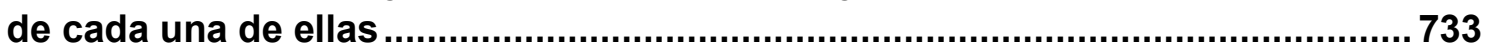

I. La derogación de las leyes secretas........................................................733

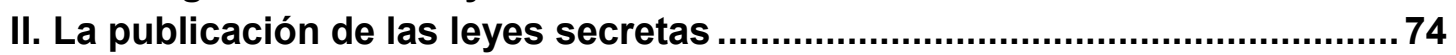

1. Fechas de su sanción y contenido mínimo. ............................................. 744

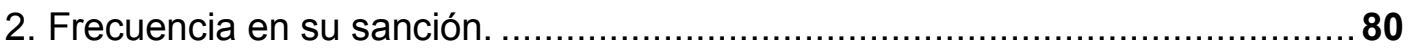

3. Gobiernos de facto y democráticos........................................................... 811

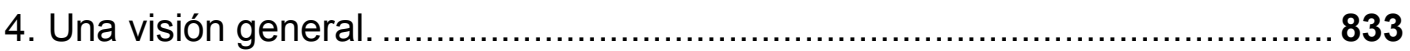

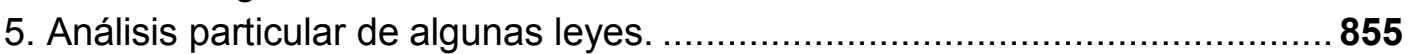

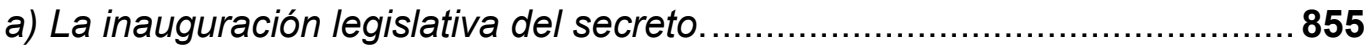

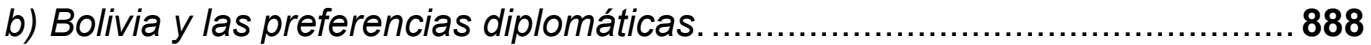

c) El caso del Paraguay...................................................... 89

d) Los gastos reservados para los funcionarios públicos.......................91

e)La protección de los

jueces...................................................... 
III. Recapitulación

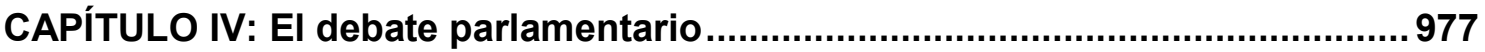

I. El marco histórico y político del debate ........................................................977

II. La composición de la Cámara de Diputados y de Senadores.................100

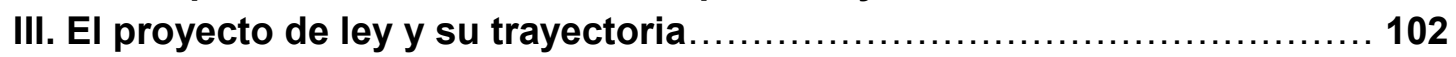

1. La discusión en la Cámara de Senadores...................................102

2. La discusión en la Cámara de Diputados................................................. 1055

IV. El debate en la prensa..................................................... 107

1. Las versiones iniciales................................................... 107

2. El debate en el Senado.................................................. 108

3. El debate en la Cámara de Diputados.................................109

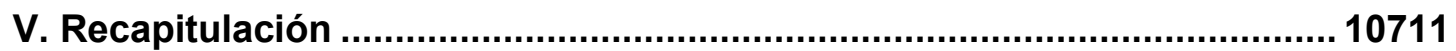

CAPÍTULO V: Las ideas de publicidad de los actos de gobierno en el debate

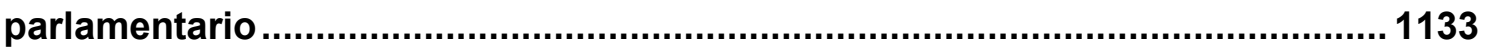

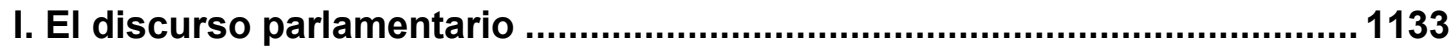

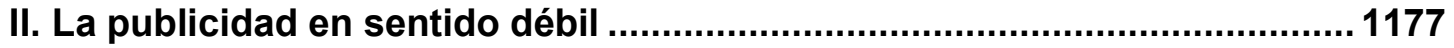

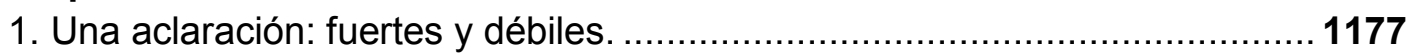

2. Una voz en la Cámara de Senadores. .................................................. 1177

3. Una voz en la Cámara de Diputados. ..................................................... 12121

III. La publicidad en sentido fuerte................................................................ 1255

IV. Luces y sombras sobre la actuación de los poderes públicos .............. 13030

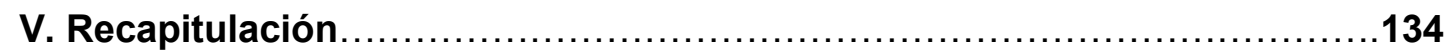

CAPÍTULO VI: Conclusiones............................................................................. 1377

I. Pasado y presente del secreto de estado en la Argentina .......................... 1377

1. La noticia es oficial: existen leyes secretas........................................ 1378

2. El discurso de la transparencia. ......................................................... 1388

3. La experiencia de los Estados Unidos de Norteamérica. ........................... 1399

4. El tema del secreto y la mentira atraviesa la historia de la filosofía política....140

5. El objeto ocultado: el contenido de las leyes secretas. .......................... 14141

6. La publicidad en sentido fuerte y en sentido débil. ................................... 14242

II. Sobre el futuro: opacidad o transparencia................................................ 143

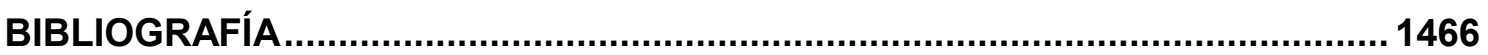




\section{INTRODUCCIÓN}

\section{PRESENTACIÓN DEL TEMA}

Este trabajo examina las ideas sobre la publicidad de los actos de gobiernos en la Argentina que se registraron en el debate parlamentario que se desarrolló en el Congreso de la Nación entre los años 2005 y 2006 y que culminó con la sanción de una ley que dispuso la derogación de las leyes secretas existentes en el país. Hasta que tomó estado público a través de la prensa, la existencia de leyes secretas era una cuestión de la que sólo se ocupaban los debates académicos ${ }^{1}$. Como consecuencia del llamado affaire ${ }^{2}$ Alsogaray que llevó ante los tribunales imputada de diversos actos de corrupción a esta funcionaria del gabinete del presidente MENEM (1989-1999), el tema comenzó a ser objeto de discusión entre las distintas fuerzas políticas. Cualquier discurso oficial contra la corrupción y a favor de la transparencia se veía neutralizado en tanto no se despejase esta cuestión. Las imputaciones de enriquecimiento ilícito que -entre otros muchos cargos- le dirigieron a la funcionaria fueron resistidas por ella con un argumento simple, contundente pero escandaloso: leyes y decretos secretos autorizaban el pago de sobresueldos. El dinero extra que había abultado su patrimonio había sido depositado por el propio Estado nacional como remuneración complementaria.

Asomaban así dos cuestiones. La primera -vinculada estrechamente con el caso- objetaba jurídica y éticamente la existencia de dichos sobresueldos, también conocidos como gastos reservados. Se trataría de una suerte de pago "en negro" conducta que, como se sabe, debe ser objeto de persecución por parte del Estado y que aquí, paradójicamente, la llevaría a cabo el encargado de erradicarla con el agravante de que los beneficiarios resultaban ser los funcionarios de más alto rango. La segunda, apuntaba al número y objeto de otras normas de carácter secreto que, probablemente, rigiesen áreas relevantes de la vida institucional. El desconocimiento sobre la

\footnotetext{
${ }^{1}$ SAgÜÉs, Néstor P., Las leyes secretas. El sigilo legislativo en el derecho constitucional argentino, segunda edición, LexisNexis, Buenos Aires, 2005.

2 Tomamos la expresión de MuZILA, Lindy- MORALES, Michelle-MATHIAS, Marianne-Berger, Tammar, Les Profiteurs Incriminer l'enrichissement illicite pour combattre la corruption, Washington, World Bank, 2014, p. 62.
} 
extensión de esta práctica podía comprometer la intangibilidad de los derechos y garantías de los ciudadanos.

Una nota periodística de la época sintetizaba así el panorama: "El gobierno de Néstor KIRCHNER se encuentra frente a la encrucijada de hacer realidad su política de calidad institucional y aceptar el pedido de la Justicia para hacer público el contenido de toda la legislación secreta vigente o, por el contrario, mantener el velo sobre el contenido de ese tipo de normas reservadas por cuestiones de seguridad o de Estado"3. Pero la situación no resultaba novedosa. Antes, el gobierno de Fernando DE LA RÚA (1999-2001) también había sido cuestionado por mantener las leyes secretas y más concretamente aquellas que habilitaban a la Policía Federal a realizar tareas de inteligencia ${ }^{4}$.

Puede afirmarse, entonces, que el referido caso judicial despertó la discusión pública de un problema conocido pero cuyas dimensiones no se advertían claramente. Parecía imperioso, para un gobierno que levantaba las banderas de la transparencia, repudiar el secreto que -además- quedaba asociado con las prácticas policiales y militares, especialmente las implementadas a partir del golpe de 1976, cuyo juzgamiento también impulsaba. Pero, al tiempo, también percibía que gobernar requería una dosis cuantitativamente imprecisa- de secreto y que la admisión pública de esa necesidad difícilmente alcanzaría apoyo popular.

Fue entonces que ganó consenso la idea de prohibir el secreto y de revelar las leyes que habían tenido dicho carácter en el pasado. El contexto histórico en el que cada una fue sancionada, el camino que siguió la cuestión y la culminación en los debates en el Congreso de la Nación ocuparán estas páginas.

\section{LA PUBLICIDAD Y EL SECRETO}

\footnotetext{
3 “La Nación”, 7 de junio de 2004.

4 "Página 12", 5 de mayo de 2000.
} 
Los sistemas democráticos se vertebran sobre el principio de publicidad. Pero no excluyen, al menos por completo, el secreto. Aquélla y éste conviven en una tensión sin tregua.

No es difícil encontrar en la vida contemporánea en la Argentina escenas que reflejen la tensión entre lo que se exhibe y lo que se esconde o se procura esconder: un gobernante en época electoral que aspira a su reelección persigue también la máxima difusión de las obras realizadas durante su gestión y, así, nuevas escuelas, hospitales, rutas, etc. aparecerán a la vista pública en todos sus detalles. Probablemente, no dedicará los mismos esfuerzos a exponer los mecanismos de contratación que se emplearon o los precios o calidades que otros constructores ofrecían. Aunque de aquí no se sigue que estos últimos aspectos constituyan un secreto de Estado ni tampoco, necesariamente, que medie un engaño o una mentira reprochable. Por el contrario, seguramente podrá considerarse que se trata de una estrategia política tolerable en una democracia. Las fuerzas opositoras, de su parte, podrán denunciar el ocultamiento y, eventualmente, emplear los instrumentos que permiten exigir la difusión de aquello que se intentaba esconder.

La tensión entre publicidad y secreto gobierna el escenario que venimos describiendo. En su funcionamiento el Estado tiene una gran inclinación hacia el secreto y los funcionarios se resisten a que su gestión sea observable. Transparentar -ya volveremos sobre el neologismo- el ejercicio de la función pública es una exigencia que deriva -como explicaremos de inmediato- de la Constitución Nacional y cuenta con una extensa trayectoria en el pensamiento político que comprende desde PLATÓN a KANT y continúa en HABERMAS Y RAWLS.

1. La publicidad de los actos de gobierno es un principio reconocido constitucionalmente.

La Argentina integra el grupo de países cuya Constitución, tratados internacionales y leyes inferiores lo establecen con singular claridad. Si se parte de una radical simplificación respecto de la organización estatal, esto es, de la existencia de tres poderes independientes, pueden formularse las siguientes observaciones. En efecto, la actividad del Poder Legislativo es pública, tanto en su etapa de elaboración como en su resultado. Es posible asistir a las sesiones de las cámaras que integran el Congreso o de sus 
comisiones. El producto final, es decir, la ley se publica en el Boletín Oficial y se da a difusión por otros medios. El Poder Ejecutivo -sin dudas, el mayor productor de actos de la tríada- está conminado también a hacer públicas sus decisiones aunque el proceso de elaboración, por así decirlo, puede permanecer reservado. Por último, el Poder Judicial debe dar a luz sus sentencias $\mathrm{y}$, además, una parte sustancial de sus procedimientos es de libre acceso. El ejemplo clásico en este ámbito está constituido por el proceso penal que tiene carácter oral y público.

Esta breve -y simplificada- descripción debe complementarse por la influencia que han ejercido sobre los mecanismos clásicos de difusión, las tecnologías contemporáneas. La asistencia a las sesiones del Congreso décadas atrás confinaba el acceso a unos pocos. Sea los que moraban en la ciudad de Buenos Aires o cercanías o los que disponían de medios -básicamente, económicos- para solventar el traslado y estancia. Hoy, este cuadro desentona con la emisión en directo por las cadenas de televisión de las sesiones y reuniones preparatorias y por la existencia misma de un canal legislativo (Senado TV) accesible a través de la internet. Pero, al mismo tiempo, el Boletín Oficial -instrumento de enorme trascendencia institucional pues no es sino a partir de la publicación que las leyes, decretos y otras disposiciones pueden aplicarse- aún sigue imprimiéndose y distribuyéndose diariamente en las dependencias administrativas y judiciales aunque es dudoso que alguien tome noticia de una nueva norma tras su lectura.

2. La universalización del acceso a la información pública.

La Argentina y otros muchos países llevan adelante políticas activas de difusión no sólo de leyes, decretos y sentencias -para confinar la enunciación a la mencionada tríada- sino de todo tipo de información pública. El denominado gobierno electrónico (e-government) facilita la tarea. La Argentina desarrolla un Plan Nacional de Gobierno Electrónico. Hoy a diferencia de décadas pasadas -y no tan lejanas- los organismos están obligados a difundir en sus páginas de internet información sobre su organización, conformación, funcionarios y empleados, funciones, remuneraciones, etc. Algunos deben proveer periódicamente de datos estadísticos. Baste abrir al azar, por ejemplo, la página de un ministerio en el orden nacional para advertir la dimensión de la información que se suministra. 
También se registra una tendencia universal a facilitar el acceso a la información pública ${ }^{5}$. Un numeroso grupo de países cuenta con leyes que regulan la cuestión ${ }^{6}$. Es una referencia relevante -por la extensa experiencia que ha generado su casi medio siglo de vigencia- el sistema consagrado en los Estados Unidos de Norteamérica que bajo la Freedom of Information Act sancionada en 1967 permite obtener relevante información en poder del gobierno. Aunque el sistema consagrado tiene una considerable amplitud, la información denominada clasificada tiene un creciente volumen, tendencia que se precipitó a partir de los hechos conocidos como 9/11 ${ }^{7}$. Pero el sistema se complementa con un mecanismo de desclasificación pautado temporalmente. $\mathrm{Y}$, pese a las críticas en cuanto a la masa de información que permanece en secreto en ese país, la aplicación de dicha ley ha sido provechosa para la Argentina, Brasil, Chile y Uruguay en la persecución de los delitos cometidos por los gobiernos militares que allí rigieron en los años setenta y comienzo de los ochenta del siglo pasado. Paradojalmente, lo que permanecía en secreto en estos últimos países por mandato de su propia legislación -o falta de legislación- salía a la luz en los Estados Unidos de Norteamérica.

De manera tardía -si se atiende a lo acontecido en otros países de América Latina- Argentina consagró un sistema de acceso a la información pública. Durante el gobierno del presidente KIRCHNER -en 2003- un

\footnotetext{
${ }^{5}$ En la última década, el derecho a la información ha sido reconocido por una cantidad cada vez mayor de países a través de la adopción de numerosas leyes sobre libertad de información. En 1990 solo 13 países habían adoptado leyes nacionales sobre libertad de información, mientras que en la actualidad hay más de 90 leyes aprobadas en la materia en países de todo el mundo y hay otras 20 o 30 en estudio. Véase MENDEL, Toby, Freedom of Information: $A$ Comparative Legal Survey, 2da edición, Paris, UNESCO, 2008, p. 3.

${ }^{6}$ La historia de las leyes sobre el derecho a la información comienza en Suecia que data de 1766. Otro país con una larga historia de legislación sobre el derecho a la información es Colombia, cuyo Código de Organización Política y Municipal de 1888 permitió que los individuos soliciten documentos que estén en manos de organismos o archivos gubernamentales. Los EEUU aprobaron una ley sobre el derecho a la información en el año 1967 y le siguió esta legislación en Dinamarca (1970), Noruega (1970), Francia (1978), los Países Bajos (1978), Australia (1982), Canadá (1982) y Nueva Zelanda (1982). Véase MENDEL, Toby, The Right to Information in Latin America. A Comparative Legal Survey, Quito, UNESCO, 2009, p. 24.

${ }^{7}$ Nos referimos a los ataques ocurridos en los Estados Unidos de Norteamérica el 11 de septiembre de 2001. En esta fecha fueron secuestrados aviones que estaban efectuando vuelos comerciales para las empresas American Airlines y United Airlines y fueron deliberadamente estrellados en distintos objetivos. Dos de ellos derribaron el complejo conocido como World Trade Center en la ciudad de Nueva York. Un tercero impactó en el edificio del Pentágono, sede del Departamento de Defensa en el estado de Virginia. Un cuarto cayó a tierra sin alcanzar ningún objetivo.
} 
decreto $^{8}$ regló el tema y lo hizo consagrando los mejores principios en la materia. Sin embargo, dos observaciones deben efectuarse. La primera, es que el Congreso ha mostrado resistencia en consagrar una ley que dote al sistema de la mayor estabilidad que confiere el rango legislativo. La segunda, es la resistencia de los propios obligados a cumplirla, esto es, la Administración Pública nacional toda. Obtener información supone, muchas veces, un difícil recorrido ante el Poder Ejecutivo primero y, luego, ante el Poder Judicial. Incluso, dependiendo de la relevancia institucional de la información, la necesidad de acudir hasta la Corte Suprema de Justicia de la Nación.

Fue en el clima generado por ese nuevo instrumento legal que en el marco de un proceso penal que involucraba a la ya mencionada funcionaria María Julia ALSOGARAY -como se señaló- se invocó la existencia de decretos y leyes secretas que justificaban las acciones por las que se la perseguía. Para defenderse respecto de la imputación de un enriquecimiento ilícito sostuvo que percibía sumas adicionales a las que nominalmente figuraban en sus recibos pero que ello no era una práctica ilícita. Esos sobresueldos se abonaban con fondos reservados autorizados por una ley secreta. Este episodio sacudió las ideas asociadas con el sistema democrático que repelen la posibilidad de leyes secretas. Algunos pensaron que se trataba de una estrategia de un abogado dispuesto a postergar una inevitable condena. Pero no. Se hacía público que existían leyes secretas. Y el Congreso decidió intervenir.

3. El Congreso comprueba la existencia de leyes secretas, las prohíbe hacia el futuro y ordena la publicación de las que lo eran.

El juzgamiento de la funcionaria antes referida tenía características paradigmáticas pues, en alguna medida, constituía un juicio a las prácticas corruptas del gobierno del que participó. Eludir los cargos invocando la existencia de una ley secreta se presentaba como una justificación de la impunidad. Surgieron entonces los interrogantes sobre la existencia misma de dichas leyes y sobre su validez en un sistema democrático. Finalmente se supo que dichas leyes existían. Un dato aliviaba la noticia. Nunca, desde 1983, se habían empleado. La democracia reciente no permitió -

\footnotetext{
${ }^{8}$ Es el 1172/03 del 3-12-2003 publicado en el Boletín Oficial un día después.
} 
no precisó, resultaría más exacto, por lo que luego se dirá- que las leyes debieran ser ocultadas.

El debate en las dos cámaras del Congreso fue objeto de detallado escrutinio por la prensa. Un periódico especializado tituló sucesivamente - apelando a un rítmico ingenio- sus notas sobre el tema: "Secretos en legislación, es mala educación" y "Secretos en legislación, atraen la corrupción". Finalmente, en agosto de 2006, el Congreso sancionó la ley 26.134. Su contenido puede sintetizarse así: a) se deja sin efecto el carácter secreto o reservado de toda ley que haya sido sancionada con tal condición; b) el Poder Ejecutivo deberá publicar las leyes que hubieran sido sancionadas como secretas; c) se prohíbe en el futuro el dictado de leyes de carácter secreto o reservado; d) los fondos reservados o secretos deben ser destinados, exclusivamente, a cuestiones de inteligencia y se prohíbe su utilización con otros propósitos y e) el control de la rendición de dichos gastos estará a cargo de la Comisión Bicameral de Fiscalización de los Organismos y Actividades de Inteligencia.

El Poder Ejecutivo cumplió con la obligación que le habían impuesto los legisladores. Se publicaron las leyes que habían sido sancionadas en secreto. Sumaban 146 que comprendían más de un siglo -la primera fue dictada en 1891- y los temas más diversos -desde compras de armas hasta obsequios entre presidentes.

\section{EL PLANTEO DEL PROBLEMA: UN DEBATE, MUCHAS IDEAS}

1. La decisión del Congreso de poner fin al secreto, estuvo precedida de un intenso debate parlamentario que se desarrolló entre 2005 y 2006. En ocasiones, la discusión parlamentaria previa pasa a segundo plano porque se prioriza el resultado. Si se enjuiciara a la ley en razón de lo que dispuso, probablemente, sería celebrada. La prohibición de leyes secretas y la publicidad de las que así fueron sancionadas constituyeron un claro avance para hacer más transparente la actividad estatal. Pero si se atiende a los antecedentes de la ley -la discusión en la Cámara de Senadores y de Diputados, los informes de las distintas Comisiones, etc.- aparecen múltiples 
interrogantes. Este debate registró una de las más importantes discusiones públicas sobre el secreto. Se reconoció que en el pasado hubo leyes secretas y se ordenó la difusión de su contenido y hacia el futuro, se prohibió que pudieran volver a sancionarse.

Los senadores y diputados de los distintos partidos, no acordaron en todo. La votación fue dividida. Triunfó un criterio, aparentemente, amplio. Las leyes, efectivamente, dejaron de ser secretas pues se difundieron y se supo su contenido. Con ello se afianzaban las exigencias democráticas de la publicidad de los actos. Pero quienes se opusieron al proyecto oficial no votaron por el secreto. Por el contrario, reclamaban mayor publicidad. Sostuvieron que para alcanzar una indispensable transparencia institucional era necesario algo más que una ley que levantara el velo de los secretos del pasado. Es que -señalaron- la mayor producción estatal de secretos no tiene su sede en el Congreso sino en el Poder Ejecutivo. Y éste quedaba al margen de la nueva ley.

La lectura de las exposiciones que realizaron todos los legisladores da cuenta de la invocación común del principio de publicidad de los actos de gobierno y de la necesidad de eliminar el secreto. Pero, cabe examinar si existe o no un desacuerdo conceptual entre ellos pues entienden el referido principio de modo diferente que los conduce a postular soluciones normativas distintas. ¿De qué hablan cuando hablan de publicidad en sus discursos? En este punto, entonces, nos planteamos el siguiente problema: ¿Cuáles son las ideas de publicidad que subyacen en los discursos de los legisladores que participaron del debate parlamentario de la ley?

A partir de ese interrogante se enhebran otros. La ley parece constituir un hito institucional, una suerte de punto de inflexión entre el secreto y la publicidad; entre la era obscurantista y la era de la transparencia. Pero ¿ha sido suficiente para alcanzar los propósitos de transparencia proclamados?; ¿hay más o menos secreto estatal?; ¿qué clase de controles se imponen sobre los secretos subsistentes?; ¿qué permitió conocer la publicación de las leyes que hasta entonces eran secretas?

2. Nuestro objetivo general será analizar las ideas de publicidad sostenidas por los legisladores en el marco del debate parlamentario de la ley que ordenó la publicación de las leyes secretas y prohibió su sanción 
para el futuro. La polifonía discursiva propia del Congreso o las Asambleas legislativas en las que cada orador interviene presentando con su voz sus propuestas impone, específicamente identificar la o las ideas de publicidad presentes en los discursos de cada uno de los legisladores que participaron en el debate parlamentario de la ley 26.134, evaluar los argumentos que han empleado para sostener sus ideas de publicidad y determinar las áreas que los legisladores consideran sujetas al principio de publicidad y qué áreas al principio del secreto. Por último y en la medida que el debate parlamentario culminó con la sanción de una ley que ordenó la publicación de las leyes secretas, nuestro objetivo también será examinar el contenido de aquellas, para delimitar qué asuntos se consideraban que debían permanecer secretos y precisar el momento histórico que le sirvió de marco.

3. En este cuadro nuestra hipótesis puede formularse en estos términos: durante el debate parlamentario de la ley que culminó con la derogación de las denominadas leyes secretas, los legisladores sostuvieron básicamente dos grupos de ideas sobre la publicidad de los actos de gobierno, una en un sentido débil o restringido y otra fuerte o amplia. Las ideas triunfantes permitieron revelar el pasado oculto cuando su difusión ya era inocua y aseguraron que la producción de secretos siguiera en manos del Poder Ejecutivo, con controles mínimos o inexistentes.

\section{EL ESTADO DE LA CUESTIÓN Y EL MARCO TEÓRICO}

El secreto de Estado es un tema que ha convocado a los pensadores de todos los tiempos, tal como se verá en los próximos capítulos. El secreto legislativo que constituye una de las especies del anterior pues se refiere a uno de los departamento del gobierno, tiene un desarrollo considerablemente menor. El secreto presidencial es generalmente admitido aunque la discusión se dirige hacia la extensión o límites de aquél. El secreto legislativo, en cambio, da origen a una discusión distinta pues, precisamente, no todos lo admiten. En otras palabras, para algunos pueden existir decretos secretos pero nunca leyes secretas. El tema ha sido analizado preferentemente por juristas. Algunos lo hacen en obras que abordan el estudio del derecho 
constitucional en general o del funcionamiento del Poder Legislativo. Otros son textos específicos.

El secreto, como se dijo, puede ser rechazado y considerado inviable en un sistema democrático. Pero si se lo acepta, surge un nuevo problema que es el de su extensión. La reflexión jurídica no es tan relevante como la que ofrece la filosofía política. De allí que los trabajos empleados surjan preferentemente de aquella disciplina.

a) Validez o invalidez constitucional de las leyes secretas.

1. Joaquín V. GoNZÁLEZ escribió un texto ya clásico comentando la Constitución Nacional. Explica que el "Congreso hace la sanción de las leyes, es decir, les imprime el carácter de su soberana voluntad para que sean obedecidas o ejecutadas; pero no entran en aplicación, sino cuando son promulgadas, esto es, aceptadas por el Poder Ejecutivo expresa o tácticamente y publicadas. La publicidad -afirma- es un requisito substancial de nuestro Gobierno; pero hay también leyes secretas, excepcionalmente dictadas para realizar propósitos de alta política, cuya divulgación podría poner en peligro la suerte de la República" ${ }^{9}$. En esa misma orientación pero de modo más terminante Juan A. GonZÁlEZ CALDERón se convierte en uno de los defensores de la validez de las leyes secretas. Tras señalar que la publicación constituye una regla general expone que "en algunos casos puede omitirse". "Tal conclusión fluye obviamente de que las cámaras pueden celebrar sesiones secretas para tratar graves asuntos de Estado, como la Corte Suprema nacional lo ha reconocido [...] Las sesiones secretas están previstas por la Constitución, ya que las cámaras tienen la facultad de darse sus reglamentos internos y determinar los procedimientos a que se sujetarán en el ejercicio de sus funciones. Si la promulgación pues puede ser tácita, nada obsta a que existan leyes secretas y las hay" ${ }^{10}$.

Arturo E. SAMPAY -jurista que ejerció notable influencia en la redacción de la Constitución de 1949- publico un relevante ensayo sobre la publicidad de las leyes. Allí expresaba que "la publicidad es una condición sine

\footnotetext{
${ }^{9}$ Manual de la Constitución Argentina, 20va., Buenos Aires, Ángel Estrada y Cía., s/d., p. 507 y 508.

${ }^{10}$ Curso de Derecho Constitucional, 6ta., Buenos Aires, Depalma, p. 378.
} 
que non de la obligatoriedad de la ley" ${ }^{\prime 1}$. Y también entre los constitucionalistas, Germán BIDART CAMPOS señala que "aunque con carácter excepcional, a veces nuestro derecho constitucional material ha conocido las leyes llamadas secretas. La ley secreta es la que, no solamente no se publica, sino que además recibe expresamente el carácter de secreta (o reservada), para que no sea conocida de manera alguna (una ley no es secreta por el solo hecho defectuoso de que no se publique oficialmente, si pese a ello se da a conocimiento público por otros medios suficientes de difusión). Como principio, la ley secreta no se compadece con el sistema republicano, por lo que sólo resulta admisible en situaciones muy excepcionales de estados reales de necesidad o secretos de estado, y cuando además su aplicación se reserva a la mera esfera interna del poder, sin alcanzar en su dispositivo a los particulares"12. De análoga opinión es Rafael BIELSA que entiende que "las leyes secretas tienen el mismo régimen constitucional que las demás, pero su aprobación y promulgación es secreta. El carácter secreto tiene su razón y duración según el hecho o las circunstancias que lo motivan"13.

2. Todos estos autores examinan tangencialmente el asunto y coinciden en que en el derecho constitucional argentino son viables las leyes secretas. Se trata de juristas de distintas orientaciones ideológicas, cuyas obras figuraban o figuran en los planes de estudios de la mayoría de las facultades de derecho del país y bajo cuyas ideas se formaron muchas generaciones de abogados.

Una notable excepción la constituye el libro Néstor $P$. SAGÜÉS. Destaca que "tan discreta ha sido y es la legislación tramitada secretamente y tan exótica parece, que para muchos juristas el asunto es prácticamente desconocido. Para ello, tales leyes no son secretas, sino irreales". La argumentación de su trabajo sobre la base de que el sistema republicano exige la publicidad de los actos de gobierno se dirige a impugnar las leyes secretas. Sin embargo, en el último párrafo del libro deja abierta la posibilidad de que las haya. No se fundan ni en "la razón de Estado ni en el bien del gobernante, sino en los últimos casos donde, de manera

\footnotetext{
11 "Sobre la publicación de las leyes", en SAMPAY, Arturo E., Estudios de Derecho Público, Constitucional, de Gentes y Eclesiástico, Buenos Aires, Editorial Toaitéia, 1951, p. 13.

${ }_{12}$ Manual de la Constitución reformada, Buenos Aires, Ediar, 1995, tomo III, p. 129.

${ }^{13}$ Derecho constitucional, 3era., Buenos Aires, Depalma, 1959, p. 485.
} 
incuestionable, está en juego la subsistencia de la República o la conservación de la comunidad nacional"14.

3. La bibliografía crece notablemente cuando comienza a tener estado público la existencia de leyes secreta ${ }^{15}$ y se inician investigaciones judiciales por los actos de corrupción acontecidos durante el gobierno del presidente MENEM como antes señalamos. Carlos J. LAPLACETTE ${ }^{16}$, Pablo D. SANABRIA $^{17}$, Luis LeIVA FERnÁNDEZ ${ }^{18}$, Fernando E. JUAN LIMA ${ }^{19}$, Marcela BASTERRA $^{20}$ y Julieta RODRÍGUEZ PRADO ${ }^{21}$ son los autores de las contribuciones más relevantes que colocan el acento en el principio republicano de la publicidad de los actos de gobierno para descalificar la validez constitucional de las leyes secretas dejando abierta -en términos generales- la puerta para postergar su difusión en casos de gravedad institucional.

Los trabajos referidos descalifican con vehemencia la validez constitucional de las leyes secretas pues consideran que implican una grave alteración de la propia esencia del carácter democrático de un gobierno. Pero encontramos que el análisis no se dirige a determinar cuáles eran las cuestiones reguladas por dichas leyes, cuáles eran las circunstancias históricas al momento de su sanción, cuáles fueron los argumentos que se expusieron en el debate parlamentario que ordenó su difusión y, por último, cuáles son las razones que justificarían la existencia de decretos del Poder Ejecutivo con carácter secreto y no de leyes del Congreso sancionadas con ese carácter. Dicho de otro modo, si se censura al secreto de Estado no es posible omitir referirse al Poder Ejecutivo que constituye el mayor productor de aquéllos.

b) La extensión del secreto en una democracia.

\footnotetext{
${ }^{14}$ Op. cit., p. 7 y 120.

${ }^{15}$ También hay estudios anteriores. Entre los más relevantes figuran RısoLíA, Marco Aurelio, "Publicidad de los actos de gobierno, ignorancia de la ley y leyes secretas", en "El Derecho" (Argentina) 68-837; LUQUI, Juan Carlos, "La falta de publicidad de las leyes y el proceso de efectivización para su vigencia", en "Jurisprudencia Argentina" (sección Doctrina), 1974 p. 572 y SALERNO, Marcelo, "Conocimiento de la norma ante el recaudo de su publicidad", en "La Ley" (Argentina), 1995-D- 448.

16 "Leyes secretas. Abusos de público y notorio", en "La Ley" (Argentina) 2007-B-1314.

17 "Un poco de luz sobre las leyes secretas", en "La Ley" (Argentina), 21-11-2006.

18“"Las leyes temporalmente secretas (Sobre la vigencia y publicación de la ley)", en "La Ley" (Argentina) 2006-E-1220.

19 "Las leyes secretas", en La Ley" (Argentina), 2005-C-695 y "Leyes secretas: Continúa el sigilo", en "La Ley" (Argentina) 2006-E-74.

20 "Inconstitucionalidad de las leyes secretas", en "La Ley" (Argentina) 2006-D-1158.

21 "Leyes secretas ¿antagónicas con un estado de derecho?" en "La Ley" (Argentina) 2005-D480.
} 
1. El compromiso con la publicidad puede asumirse en términos absolutos o relativos. En el primer caso, todo secreto debe ser eliminado; en el segundo, algunos pueden subsistir. $Y$ este último camino conduce al concepto del secreto democrático ${ }^{22}$. La democracia requiere publicidad pero algunas políticas democráticas requieren secreto. La democracia también exige responsabilidad de los gobernantes pero para hacerla efectiva, los ciudadanos precisan conocer qué es lo que hacen. Este dilema puede, en alguna medida, ser resuelto aplicando tres técnicas: a) que los secretos sean temporarios, esto es, que no se conviertan en permanentes; b) que los secretos sean parciales y que no se conviertan en totales y c) que la decisión de conservar en secreto cierta resolución o política, sea hecha públicamente.

La vida política en la Argentina -aunque lo propio podría afirmarse de la de otros países- revela que dificultades para evitar el secreto representan una de las promesas incumplidas de la democracia ${ }^{23}$. Ello no sólo afecta democracias con pobre o deficiente calidad institucional sino también a sociedades con mayor tradición democrática que, por su influencia en el escenario mundial, aíslan ciertas resoluciones estratégicas del debate público y la decisión democrática ${ }^{24}$.

2. El secreto ha acompañado el funcionamiento de los gobiernos desde épocas remotas. Los ha acompañado sin reparar en su origen, autocrático o democrático. $\mathrm{Y}$ no los ha abandonado hasta el presente. El secreto es una sombra. Se extiende y se contrae. Pero no desaparece. La publicidad de los actos de gobierno está en el centro del sistema democrático. Y aunque no hay acuerdo en definir a la democracia, en cambio, sí puede afirmarse que un número importante de autores señalan a la publicidad como una de sus características imprescindibles. Sin publicidad no hay democracia o,

\footnotetext{
22 THOMPSON, Dennis F., "Democratic Secrecy", en "Political Science Quarterly", vol. 114, n 2 (1999), p. 181 y reproducido en la obra del mismo autor Restoring Responsibility Ethics in Government, Business, and Healthcare, Cambridge, Cambridge University Press, 2004, p. 129, capítulo 6.

${ }^{23}$ BOBBIO, Norberto, "Democracia y Secreto", publicado en el libro Norberto Bobbio: el filósofo y la política (Antología), trad. de José FERnÁNDEZ SANTILLÁN y Ariella AURELI, Fondo de Cultura Económica, México, 1996, p. 294.

${ }^{24}$ IAZZETTA, Osvaldo M., "La democracia y los vaivenes de lo público-estatal", "Revista Sociedad Argentina de Análisis Político (SAAP)". vol 1, № 2.p.377 (2003).
} 
al menos, sin una publicidad que sólo pueda ser limitada excepcional y justificadamente.

Por cierto, no hay un modelo de democracia único. Del inmenso y laberíntico universo respecto de la noción de democracia escogeremos los trabajos de Robert DAHL y Norberto BOBBIO y ello por el énfasis que sus concepciones colocan en la publicidad. El primero proporciona una lista de "requisitos para que se dé la democracia entre un gran número de habitantes". En ella incluye dos puntos relacionados con la publicidad. Afirma que debe existir "diversidad de fuentes de información" y presencia de "instituciones que garanticen que la política del gobierno dependa de los votos y demás formas de expresar las preferencias". DAHL aclara que la "diversidad de las fuentes de información" se refiere a la existencia de una prensa libre: "los adultos en la organización [deben tener] accesibles a ellos diversas fuentes alternativas de información, incluyendo algunas que no estén bajo un control unilateral y significativo de los líderes del gobierno. Accesibles en este contexto quiere decir únicamente que los miembros que así lo deseen puedan utilizar estas fuentes sin incurrir en penalidades iniciadas por los líderes del gobierno o sus subordinados". Añade -finalmente- que "los defensores de la democracia han dotado de un alto valor a la educación. Y la educación cívica no sólo requiere una escolarización formal, sino discusión, deliberación, debate y controversia públicas, disponibilidad efectiva de información fiable y otras instituciones de una sociedad libre"25.

Por su parte, BOBBIO define a la democracia como el "gobierno del poder público en público". Destaca que no hay definición de aquélla "que pueda excluir de sus connotados la visibilidad o transparencia del poder". Puesto que en la democracia el poder emana de la mayoría, los gobernados necesitan conocer sus acciones para evaluar la actuación de los gobernantes. "La obligación de la publicidad de los actos gubernamentales es importante no sólo, como se dice, para permitir al ciudadano conocer las acciones de quien detenta el poder y en consecuencia de controlarlos, sino también porque la publicidad es en sí misma una forma de control, es un expediente que permite distinguir lo que es lícito de lo que es ilícito. No por

\footnotetext{
${ }^{25}$ On Democracy, Yale University Press, New Haven-London, 2000, p. 85.
} 
casualidad, la política de los arcana imperii corre paralela a las teorías de la razón de Estado, es decir, a las teorías para las cuales le está permitido al Estado lo que no le está permitido a los ciudadanos privados y por tanto el Estado está obligado a actuar en secreto para no hacer escándalo"26.

3. Ahora bien, el término público, como la mayor parte de los conceptos políticos relevantes, está muy lejos de una definición inequívoca $^{27}$. Se lo utiliza para adjetivar espacio, esfera; se lo sustantiva; se lo usa normativa o descriptivamente y no siempre se tiene en cuenta que el trazado de los límites entre lo público y lo privado se modifica históricamente. Esta gran dicotomía público-privado tiene, también, un uso descriptivo y un uso axiológico ${ }^{28} \mathrm{y}$, de manera general, presenta tres sentidos básicos. En sustancial síntesis y con relación a cada uno de ellos puede señalarse: a) lo público como lo que es de interés o de utilidad común a todos, lo que atañe a la comunidad en contraposición a lo privado, entendido como aquello que se refiere a la utilidad y el interés individual; b) lo que es y se desarrolla a la luz del día, lo manifiesto y ostensible en contraposición a aquello que es secreto, preservado, oculto y c) lo que es de uso común, accesible para todos, abierto, en contraposición con lo cerrado, que se sustrae a la disposición de los otros ${ }^{29}$.

Esta segunda acepción -lo público como opuesto a lo secreto- vertebrará nuestro análisis. Así definida, se corresponde con la expectativa iluminista de poner límites a la discrecionalidad y arbitrariedad de los poderes despóticos ${ }^{30}$ y connota tanto la idea de publicidad como la de rendición de cuentas a las que están sometidos los poderes públicos ${ }^{31}$. Estas ideas jugarán un papel muy relevante para examinar el debate parlamentario citado pues, en muchos de sus pasajes, se asoció la existencia del secreto con

\footnotetext{
${ }^{26}$ El futuro de la democracia, traducción de José F. Fernández Santillán, tercera edición, Fondo de Cultura Económica, México, 2005, p. 94.

${ }^{27}$ RABOTNIKOF, Nora En busca de un lugar común. El espacio público en la teoría política contemporánea, México, Universidad Nacional Autónoma de México, 2005, p. 9 y siguientes.

${ }^{28}$ BOBBIO, Norberto, "Democracia y Secreto", op. cit., loc. cit.

${ }^{29}$ RABOTNIKOF, Nora, op. cit., loc. cit.

${ }^{30}$ KANT, Immanuel: La paz perpetua, traducción de F. Rivera Pastor, novena edición, Espasa Calpe, Madrid, 1997.

${ }^{31}$ IAZZETTA, Osvaldo M., "La democracia y los vaivenes de lo público-estatal", "Revista Sociedad Argentina de Análisis Político (SAAP)", vol 1, No 2. p. 377 (2003) y O'DONNELL, Guillermo: "Acerca de varias 'accountabilities' y sus interrelaciones", en PERUZzOTTI, Enrique y Catalina SMULOVITZ, Controlando la política. Ciudadanos y medios en las nuevas democracias latinoamericanas, Buenos Aires, Temas, 2000.
} 
los gobiernos autoritarios. En otros términos, lo que los diputados y senadores argentinos manifestaron fue que un gobierno democrático debía procurar la eliminación del secreto. Y por ello ordenaron la publicación de las leyes que, hasta entonces, habían permanecido ocultas.

4. El enfoque del secreto desde la filosofía política también se verá enriquecido por una mirada sociológica. En este sentido el pensamiento de Georg SIMMEL es gravitante pues su obra ha analizado el secreto desde diversas perspectivas; en la vida cotidiana, en los negocios, en el matrimonio, en la amistad, etc. Mujeres y hombres -concluye- "estamos hechos de tal manera, que no sólo necesitamos, como se indicó antes, una determinada proporción de verdad y error como base de nuestra vida, sino también una mezcla de claridad y oscuridad, en la percepción de nuestros elementos vitales"32. Es posible que esa necesidad también resulte inevitable en la vida pública.

\section{FUENTES Y CONSIDERACIONES METODOLÓGICAS}

1. El corpus que constituye la base de esta investigación ha sido extraído del Diario de Sesiones tanto de la cámara de senadores como de la cámara de diputados de la Nación que constituyen documentos oficiales. La fuente se enmarca en el ámbito de la lengua escrita o, por decirlo de otro modo, en la reproducción escrita de un discurso previamente oralizado. En concreto, se trata del texto de las sesiones correspondientes a las fechas en que se registró, en cada una de ellas, el debate. Para la primera, el día 15 de junio de 2005. Para la segunda, el 16 de agosto de 2006. El corpus también está conformado por una serie de documentos oficiales que son complementarios. Se trata, en primer lugar por su importancia, del dictamen de la Comisión de Asuntos Constitucionales de la Cámara de Diputados de la Nación (Orden del día № 754 correspondiente a las sesiones ordinarias de 2006), de la nómina de diputados y senadores que integraban las cámaras a las fechas en que se produjeron los debates y del informe de la votación de los legisladores en cada sesión. También conforma el corpus los ejemplares del Boletín Oficial

\footnotetext{
${ }^{32}$ The Sociology of Georg Simmel, Illinois, The Free Press, 1950, p. 307 y siguientes.
} 
correspondientes a los sesenta días posteriores a la sanción de la ley examinada pues dicho plazo fue el que el Congreso estableció para dar a publicidad las leyes secretas.

Inicialmente, se analizarán estos últimos documentos. Ello permitirá conocer las leyes que fueron sancionadas como secretas, las fechas en que ello ocurrió y, por supuesto, su contenido. Tras ello, se determinará la composición de ambas cámaras del Congreso, la conformación partidaria y el sentido de la votación - a favor o contra de la sanción del proyecto- tarea que permitirá ver las posiciones de confrontación y colaboración propias de la actividad parlamentaria. Predomina aquí un enfoque cuantitativo. Luego, la evaluación del dictamen de la Comisión de Asuntos Constitucionales -que contiene una mayoría y una minoría- permitirá confrontar las razones de uno y otro y, con ello identificar, anticipadamente, las nociones de publicidad que los legisladores sostendrán más tarde en el recinto.

2. La prensa también ha sido empleada como una fuente relevante. Examinaremos los artículos aparecidos en los periódicos antes, durante y después de los debates parlamentarios. En este sentido limitaremos la consulta a los diarios "Clarín" y "Página12" -ocasionalmente habrá referencias a "La Nación"- pues representan corrientes editoriales distintas, ambos son periódicos de circulación nacional y, pese a sus diferencias, en sus columnas se reclamó con insistencia sobre la necesidad de contar con una ley que organizase el acceso a la información pública para permitir el debate sobre temas de interés público de modo desinhibido, robusto y ampliamente abierto.

3. A lo largo del trabajo, emplearemos algunas de las herramientas proporcionadas por el Análisis Crítico del Discurso. Considerado una teoría y un método al mismo tiempo, éste permite considerar al discurso como una práctica social, que debe ser situado en el contexto del que la/o acciona y del que la/o recibe y que tiene como fin analizar cómo se manifiestan a través del lenguaje las relaciones de poder y control.

El debate parlamentario que ocupará parte de este estudio está sujeto a reglas que no puede soslayarse a la hora de examinarlo. En efecto, es posible distinguir el discurso político en sus manifestaciones más clásicas del discurso parlamentario como un campo híbrido que mantiene algunas de las características de aquél pero, al mismo tiempo, se distancia por 
el ámbito de producción, por la forma de circulación y por su finalidad específica. Puede afirmarse, entonces, que constituye en este sentido un subgénero de discurso político ${ }^{33}$, caracterizado por su complejidad ${ }^{34}$.

El discurso parlamentario consiste en discursos, intervenciones de distinta índole tales como preguntas, respuestas, etc. y diálogos entre los miembros de un parlamento. Se desarrolla en un lugar específico -el recinto del Congreso- con ubicaciones precisas de sus participantes, de modo interactivo y gobernado por normas que establecen los modos de participación de los legisladores ${ }^{35}$. Pero, desde otra perspectiva, también se ha observado que lo realmente distintivo no es el estilo argumentativo ni las características de la interacción ni el lenguaje ni el espacio en que se desenvuelve. Todas estas propiedades también se pueden encontrar en otros géneros. Ninguna de estas características son exclusivas del discurso parlamentario, lo que es realmente típico del discurso parlamentario es la combinación de todas ellas ${ }^{36}$.

En síntesis, con ayuda de esta herramienta, se analizarán todas las participaciones de los legisladores que hicieron uso de la palabra El análisis del debate parlamentario se realizará de manera exhaustiva en torno al eje de la investigación, esto es la presencia y extensión de las ideas de publicidad, prestando especial atención a las fuerzas políticas a las que pertenecen los oradores, la relación entre su discurso y su voto, tanto en general como en particular y los diferentes significados asignados a un mismo significante.

\section{ESTRUCTURA DEL TRABAJO}

\footnotetext{
${ }^{33}$ MARAFIOTI, Roberto, "Discurso parlamentario: entre la política y la argumentación", en MARAFIOTI, R. (Editor), Parlamentos. Teoría de la argumentación y debate parlamentario, Buenos Aires, Biblos, 2007, p. 99.

${ }_{34}$ BITONTE María Elena y DUMM, Zelma, "El discurso parlamentario: ¿diálogo en la torre de Babel?", en MARAFIOTI, R. (Editor), Parlamentos. Teoría de la argumentación y debate parlamentario, cit., p. 173.

${ }_{35}$ ILIE, Cornelia, "Parliamentary Discourses", en BROWN, Keith (ed.) Encyclopedia of Language and Linguistics, 2da, Oxford, Elsevier, 2006, volumen 9, p. 188-197.

${ }^{36}$ VAN DIJK, Teun A., "La contextualización del discurso parlamentario: Aznar, Iraq y la pragmática del mentir" en CORTÉs RODRÍGUEZ, Luis María (coordinador), Discurso y oralidad: homenaje al profesor José Jesús de Bustos Tovar, Madrid, Arco Libros, 2007, volumen 1, p. 137. La traducción del artículo corresponde a Jesús G. MARTínEZ DEL CASTILLO.
} 
El trabajo está estructurado en seis capítulos.

En el capítulo I, se hará un recorrido por el pensamiento político clásico -PLATÓN, MAQUIAVELO, LOCKE, KANT- con relación al secreto de Estado y a la publicidad de los actos de gobierno. Se examinará la denominada gran dicotomía público/privado y se identificarán los sentidos que se han asignado a lo público. También se distinguirá el secreto de estado de otras modalidades ligadas a aquél como la mentira política $u$ otras formas del engaño y, en este caso, se volverá a las ideas de MAQUIAVELO. En razón de la importancia de sus contribuciones se expondrán las ideas de CONDORCET, ARENDT, KOYRÉ Y DERRIDÁ.

En el Capítulo II, se tratarán también en términos generales las ideas sobre publicidad y secreto desde KANT -pasando por la Revolución Francesa- hasta pensadores contemporáneos como Reinhart KOSELLECK, Hannah ARENDT, Jürgen HABERMAS y Michel FouCAULT. Se discutirá la relación entre democracia y secreto. Esto es, si este último tiene espacio en un sistema democrático, si debe excluírselo o, menos radicalmente, si debe reducírselo y, en tal caso, con qué límites. Se intentará alcanzar la noción de secreto democrático. Por último, se vincularán las ideas clásicas y contemporáneas expuestas en éste y en el anterior capítulo, con los debates ocurridos en la Argentina desde la instalación de la Junta de Gobierno en 1810, pasando por el proceso constituyente de 1853-1860, hasta el presente.

En el Capítulo III se identificarán las leyes que habían sido sancionadas como secretas. Mediante un cuadro comparativo se mostrará la fecha de su sanción y un contenido mínimo. Se establecerá su número definitivo y los gobiernos que las dictaron, distinguiendo especialmente aquellas que corresponden a gobiernos democráticos de las que surgieron bajo la vigencia de gobiernos de facto. Se analizarán algunas especialmente, sea en virtud de su contenido sea en razón del contexto histórico en el que nacieron.

En el Capítulo IV se describirá el debate parlamentario que prohibió el dictado de leyes secretas en la Argentina e impuso la publicación de la que tenían esa condición. Se precisarán las circunstancias políticas en las que se generó, el origen del proyecto, la conformación de los distintos bloques legislativos, su trámite y las posiciones que asumieron los distintos partidos políticos. Se expondrán por separado las intervenciones relevantes de los 
legisladores tanto en el Senado como en la Cámara de Diputados. También se reseñarán las repercusiones contemporáneas que tuvo el debate en la prensa.

En el Capítulo V se distinguirán los distintos conceptos de publicidad que se emplearon durante el debate. Se contrastarán las posiciones que asumieron los legisladores respecto del secreto legislativo y el secreto ejecutivo. Se indagará si la publicidad de las leyes sancionadas con carácter secreto constituyó o no una contribución a la transparencia democrática. $\mathrm{O}$, en otras palabras, cuánto secreto subsiste y si ello es aceptable a la luz de las ideas de publicidad expuestas en el trabajo.

El capítulo VI y final contendrá las conclusiones de la investigación. 


\section{CAPÍTULO I \\ LA PUBLICIDAD Y EL SECRETO EN EL PENSAMIENTO POLÍTICO}

\section{INTRODUCCIÓN}

El secreto ha acompañado el funcionamiento de los gobiernos desde épocas remotas. Los ha acompañado sin reparar en su origen, autocrático o democrático. $Y$ no los ha abandonado hasta el presente. El secreto es una sombra. Se extiende y se contrae. Pero no desaparece.

La transparencia en los asuntos del Estado no es una suerte de moda académica o plan partidario en vísperas de elecciones. Tiene como se ha destacado- una larga trayectoria intelectual que comprende desde PLATÓn a KANT y desde WEBER pasando por BoBBio hasta HABERMAS.

El recurso del secreto "ha sido considerado a lo largo de la historia la esencia del arte de gobernar" y quien "quisiese recopilar en las obras políticas de cualquier época máximas sobre la necesidad del secreto de Estado no tendría más que la molestia de seleccionar"37.

Un recorrido por los textos clásicos y contemporáneos muestra que el secreto y el engaño han convocado a los pensadores de todos los tiempos.

\section{SOBRE EL PRINCIPIO DE PUBLICIDAD}

La palabra publicidad es polisémica. Una de sus acepciones está asociada a la propaganda comercial; otra, con sentido más técnico se refiere a la difusión de los actos de gobierno. Algunos autores han procurado reemplazarla por transparencia o visibilidad e, incluso, hallan diferencias entre esos conceptos. Si se tolera el neologismo, hoy no es sólo imperativo publicar sino transparentar. Si se parte de la premisa weberiana de que el gobierno funciona como una caja negra, vedada al conocimiento del público, en donde el secreto y el ocultamiento de la información se justifican por

${ }^{37}$ Воввіо, Norberto, “Democracia y Secreto", cit., p. 294. 
supuestas razones de estado, es natural suponer que todo esfuerzo de apertura debe incluir necesariamente un incremento de la transparencia ${ }^{38}$. En esta orientación se habla de publicidad activa, que constituye aquella en la que el gobierno pone los datos a disposición de la ciudadanía, en portales y páginas web, sin esperar a que los ciudadanos los demanden. Por nuestra parte, estimamos conveniente mantener la expresión publicidad de los actos de gobierno pues cuenta con una extensa tradición en la historia del pensamiento político.

El término público como la mayor parte de los conceptos políticos relevantes está lejos de una definición inequívoca. Es posible reconocer tres sentidos básicos asociados a aquél: a) existe una prolongada tradición que lo asocia a lo común y lo general en contraposición a lo individual y lo particular; se habla del interés público en contraposición al interés privado. Público alude a lo que es de interés o de utilidad común a todos los miembros de la comunidad política. En esta acepción público se vuelve progresivamente sinónimo de político; b) aquí lo público se contrapone a lo oculto, esto es, lo público es lo no secreto. El principio de publicidad - esto es muy relevante para el desarrollo que sigue- recogerá básicamente esta segunda acepción y c) en un último sentido público remite a la idea de lo abierto en contraposición a cerrado; aquí se enfatiza la accesibilidad en contraposición a la clausura y así se habla de lugar públicos o de paseos públicos ${ }^{39}$.

La publicidad en el sentido al que nos referiremos puede definirse como la exigencia de hacer visibles y conocidas las decisiones, los procedimientos, las acciones y las razones del poder político. Sin embargo no es tan claro que política y publicidad (en el sentido de salir a la luz, de dejar de ser secreto) se relacionen tan fácilmente. Las tensiones y problemas entre ambas han ocupado buena parte de la reflexión política. El denominado secreto de Estado, la razón de Estado, la emergencia o las situaciones críticas y la rapidez decisional se han invocado de forma reiterada para poner en tela de

\footnotetext{
${ }^{38}$ OSZLAK, Oscar, "Gobierno abierto: Hacia un nuevo paradigma de gestión pública" en OsZLAK, Oscar-KAUfMAN, Ester, Teoría y práctica del gobierno abierto: Lecciones de la experiencia internacional, Ottawa, IDRC, Red GEALC, OEA, 2014, p. 22.

${ }^{39}$ Seguimos aquí a RABOTNIKOF, Nora En busca de un lugar común. El espacio público en la teoría política contemporánea, cit. , p. 9 y siguientes. Consultamos, asimismo, un trabajo anterior: RABOTNIKOF, Nora, El espacio público y la democracia moderna, México, Instituto Federal Electoral, 1997.
} 
juicio el carácter público (en sentido de manifiesto o sabido) de la política. La discusión sobre la publicidad política se ubica, por lo regular, en los debates sobre la relación entre moral y política. Algunos sostienen la idea de la publicidad como piedra de toque de una determinada acción política, en tanto otros defienden una concepción de la política como una actividad específica con actores privilegiados, reglas propias y criterios autónomos, con un punto de vista independiente de consideraciones morales. Desde esta perspectiva moral, la publicidad funciona como un puente articulador de la moral y la política, como un equilibrio entre los intereses privados y los intereses generales.

Desde su origen, la publicidad política ha tenido la función de ejercer un control normativo del poder absoluto. Se atribuye a esta función de la publicidad, desde la formulación de la ley y el Estado de derecho (en su versión más clásica), hasta la afirmación de ámbitos de argumentación, debate y gestación del consenso. En todos los casos, se plantea como alternativa, postergación infinita $\mathrm{o}$ freno de la violencia directa, y también como racionalización del arbitrio. Esta función racionalizadora apunta a la posibilidad de clarificar, formular y generalizar las decisiones, procedimientos y acciones del poder político, así como de argumentar sobre ellas y a sentar principios de control y revisión frente a las apropiaciones privadas de la ley y del poder político. En ese sentido, la exigencia de publicidad del poder político, podemos adelantar, involucra cuatro elementos: visibilidad, cognoscibilidad, accesibilidad y controlabilidad ${ }^{40}$. Éstos elementos también se localizan en el pensamiento bobbiano que afirma -además- que la mayor o menor relevancia de la opinión pública como opinión relativa a los actos públicos depende de la mayor 0 menor oferta al público de los actos de quien ejerce el poder supremo. La publicidad así entendida es una categoría típicamente iluminística "en cuanto que representa bien uno de los aspectos de la batalla de quien se considera llamado a derrotar el reino de las tinieblas: doquiera haya extendido su propio dominio, la metáfora de la luz y del esclarecimiento (de la Aufklärung o de la Enlightment) se adecua bien a la representación del contraste entre poder visible y poder invisible" ${ }^{\prime 1}$.

\footnotetext{
${ }^{40}$ RABOtNiKof, Nora, op. cit., ps. 16, 17, 18 y 43.

${ }^{41}$ BoBBIO, Norberto, El futuro de la democracia, cit,. p. 100.
} 


\section{PUBLICIDAD Y SECRETO: UN PASEO POR LA FILOSOFÍA POLÍTICA ${ }^{42}$}

La discusión que plantea la tensión existente entre publicidad y secreto es de antigua data y puede hallarse desde el pensamiento clásico hasta nuestros días. El panorama general que nos hemos propuesto trazar puede desarrollarse a partir de los modelos de publicidad que se sucedieron en diversas épocas que comienza con los denominados arcana imperii, continúa con la razón de Estado, atraviesa la llustración y arriba a la democracia contemporánea.

\section{Los arcana imperii}

La expresión puede traducirse como secretos del imperio o del Estado. Sin embargo, en la experiencia histórico-política se presentan como "verdades y conocimientos, informaciones y evaluaciones, argumentos y discursos, exclusivos de los hombres del poder. $Y$ estos elementos del saber no son accesorios o laterales para el ejercicio del poder y del dominio, son más bien la condición que los hace posibles". En otras palabras, los arcana imperii son claves exclusivas y excluyentes, información selecta y privilegiada que confiere poder a los sujetos que la poseen y por tanto, condicionan las relaciones políticas de dominación y gobierno. No se trata de saber más que otros sino de dominar o gobernar a otros en razón de ese saber. Se conectan con lo sacro, con lo iniciático, lo ritual. Son algo así como los "misterios insondables de la política"43.

El origen de esta expresión se atribuye a TÁCITO ${ }^{44}(55-120)$, aunque ya en la Grecia antigua se pueden identificar algunos registros. En PLATÓN, por ejemplo, encontramos la primera teoría de la justicia basada en un régimen organicista y totalitario, donde cada uno ocupa el lugar que le corresponde en un orden jerárquico inamovible. Este modelo de sociedad justa estratificada sostiene que las razones y verdades de la política, junto con las

\footnotetext{
${ }^{42}$ Tomamos el título del ensayo de RodRíGuez ZEPEDA, Jesús, Estado y transparencia: un paseo por la filosofía política, México, Instituto Nacional de Transparencia. Acceso a la Información y Protección de Datos Personales, Cuadernos de Transparencia, $N^{\circ} 4$.

${ }^{43}$ RodRíGUeZ ZEPEDA, Jesús, op. cit., p. 14 y 15.

${ }^{44}$ Cornelio TÁcITO empleó la expresión secretos del imperio para caracterizar la política de TIBERIO, segundo Emperador de Roma (14-37). Véase Anales, trad. de Carlos Coloma, 4ta ed., México, Porrúa, 2005, p. 51 (Libro II, 36).
} 
claves de la vida pública y el Estado, solamente son accesibles para una minoría destinada a gobernar. El llamado gobierno del rey-filósofo o filósofo-rey, es un modelo de aristocracia intelectual que clausura la posibilidad de la participación en la toma de decisiones políticas a todos aquellos que no cuentan con los conocimientos o atributos suficientes ${ }^{45}$. El saber político es un saber científico, racional y especializado sólo accesible para unos cuantos. De esta forma, el filósofo, en su función política, es el indicado para guiar a la sociedad por el camino del bien, la virtud, la belleza y la verdad en tanto es el único facultado para entenderlos. Es recurrente en PLATÓN el ejemplo de cómo gobernar una nave ¿quién debe dirigirla, quien tenga más dinero, quien sea más numeroso, quien sea más fuerte? La respuesta es obvia: la nave debe ser gobernada por quien más sabe, por el piloto; del mismo modo el estado debe ser dirigido por aquellos que tengan un conocimiento más perfecto sobre la realidad: los filósofos ${ }^{46}$. O, con sus palabras: en tanto éstos "no reinen en las ciudades, o en tanto que los que ahora se llaman reyes y soberanos no sean verdadera y seriamente filósofos, en tanto que la autoridad política y la filosofía no coincidan en el mismo sujeto, de modo que se aparte por la fuerza del gobierno a la multitud de individuos que hoy se dedican en forma exclusiva a la una o a la otra, no habrán de cesar [...] los males de las ciudades ni tampoco, a mi juicio, los del género humano" ${ }^{47}$.

Por su parte, ARISTÓTELES, llamó a estos secretos de la política sophismata ${ }^{48}$. En su concepción, estos secretos son los que permiten el ejercicio del poder basado en el ocultamiento y la simulación. Son piezas del saber que hacen posible que se gobierne en función de los intereses particulares del gobernante y que distingue, de manera insuperable, a éstos de sus súbditos ${ }^{49}$.

La teoría de los arcana imperii se construye sobre dos argumentos: "uno, intrínseco a la naturaleza misma del sumo poder, cuyas acciones pueden tener mayor éxito conforme son más rápidas $\mathrm{e}$

\footnotetext{
${ }^{45}$ Véase República, trad. de Antonio Camarero, 3ra., Buenos Aires, Eudeba, 1963, p. 341 y 342 (Libro VI, 488, b, c, d y e).

${ }^{46}$ RoDRíGuez ZePEDA, Jesús, op. cit., p. 13.

${ }^{47}$ Véase República, cit., (Libro, V, 473, d), p. 318.

${ }^{48}$ Algunos autores consideran que, en la literatura posterior, la voz arcana es empleada como el equivalente latino de sophismata. Véase Donaldson, Peter S., Machiavelli and Mystery of State, Cambridge, Cambridge University Press, 1992, p. 117.

${ }^{49}$ Rodríguez ZePEDA, Jesús, op. cit, p. 15.
} 
imprevisibles...otro, derivado del desprecio por el vulgo, considerado como objeto pasivo, como la "bestia salvaje" que debe ser domesticada, dominada por fuertes pasiones que le impiden formarse una opinión racional del bien común...". Funciona, además, en dos registros complementarios, uno institucional y otro psicológico: "el primero autoriza al soberano a no hacer saber anticipadamente qué decisiones tomará y a no hacerlas conocer después de que las tomó; el segundo lo autoriza a esconder las decisiones tomadas, o sea, a disimular, o a presentarlas de diferente manera, es decir, a simular"50.

\section{La razón de Estado.}

La doctrina de la razón de Estado, por su parte, surge a la par del Estado en el siglo XVI. De la mano de un proceso de secularización social y política, los discursos trascendentales y religiosos se fueron separando poco a poco de los discursos políticos. En la Edad Media y en particular en la llamada Baja Edad Media, los arcana imperii fueron, simultáneamente, arcana ecclesiae, misterios trascendentes, dogmas de fe y verdades indiscutibles. La razón de Estado era, entonces, razón eclesiástica, puesto que nada exclusivo podía reclamar para sí el poder político dada su condición derivada del poder espiritual de la iglesia ${ }^{51}$.

La expresión razón de Estado tiene un uso y una historia. En su acepción actual designa un modo de intervención del poder político que deroga el derecho común o positivo. La razón de Estado es, en este sentido, "la parte oscura, secreta, inconfesable del ejercicio del poder; el residuo irreductible del no-derecho que acompaña al arte de gobernar, cuando lo exige la necesidad"52. En el plano de la historia, la noción sólo hacia fines del siglo $\mathrm{XVI}$ se convirtió en objeto de examen teórico.

MAQUIAVELO constituye una cita obligada. Es el único pensador político cuyo nombre ha pasado al uso común para designar una clase de política que existe y continuará existiendo independientemente de su influencia, una política guiada exclusivamente por consideraciones de

\footnotetext{
${ }^{50}$ BoBBIO, Norberto, Estado, gobierno y sociedad. Para una teoría general de la política, trad. de José F. FERnÁndez SANTILLÁN, México, Fondo de Cultura Económica, 2005, p. 37.

${ }^{51}$ RodRíGUEZ ZEPEDA, Jesús, op. cit, p. 17.

${ }^{52}$ ZaRKA, Yves C., voz Raison d'Etat en RaYnaUd, Philippe y RIALS, Stéphane, Dictionnaire de philosophie politique, 3era. edición, Paris, Quadrige-Puf, 2005, p. 612.
} 
conveniencia, que usa todos los medios, correctos o tramposos, hierro o veneno, para lograr sus fines. Ese fin puede ser el engrandecimiento de la patria pero también frecuentemente usa la patria para el auto engrandecimiento del político o del propio partido ${ }^{53}$. En su obra -aunque nunca menciona la expresión razón de estado- suministra sin embargo, todos los elementos teóricos para poder pensarla a partir de él.

En una perspectiva histórica se pueden identificar tres momentos particularmente significativos del concepto razón de Estado. El primero se ubica en los umbrales de la Edad Moderna y está representado por las reflexiones de MAQUIAVELO a través de las cuales comienza a surgir una concepción sobre la función del Estado articulada a la necesidad de emplear todos los medios disponibles para su mantenimiento. Aparece aquí la tesis de la razón de Estado, aunque todavía no su formulación precisa. Sin embargo, es solo con él que se registra un salto cualitativo en la historia del pensamiento político al punto de constituir el principio de una nueva escuela de pensamiento. El segundo momento de esta tradición, está constituido por las reflexiones y análisis específicos realizados por los teóricos de la razón de Estado como Giovanni BOTERO, quienes tienen en perspectiva los intereses de los estados nacionales durante el siglo XVI, a los cuales se deben mayores precisiones y profundizaciones de este concepto así como la introducción definitiva de la expresión razón de Estado en el significado que todavía tiene en nuestros días. El tercer momento en la evolución del término razón de Estado, es cuando alcanza su máximo esplendor y sus más altos niveles de conceptualización, sobre todo en la cultura alemana, entre los siglos $\mathrm{XIX}$ y $X X^{54}$.

En una definición general puede afirmarse que la doctrina de la razón de estado sostiene que la seguridad del Estado es una exigencia de tal importancia que los gobernantes se ven constreñidos, para garantizarla, a violar las normas jurídicas, morales, políticas, económicas, etc. que

\footnotetext{
53 Véase "Niccolo Machiavelli" en Strauss, Leo-CropseY, Joseph, History of Political Philosophy, 3era ed., Chicago-London, The University of Chicago Press, 1987, p. 296 y sigts.).

${ }^{54}$ CISNEROS, Isidro H., Norberto Bobbio: de la razón de Estado al gobierno democrático, México, Instituto Electoral y de Participación Ciudadana del Estado de Jalisco, 2014, ps. 201 y 202. Un estudio integral de la cuestión se halla en la obra capital de Friedrich MEINECKE, The Doctrine of Raison d'Etat and Its Place in Modern History. Machiavellism, trad. Douglas Scott, New Brunswick-London, Transaction Publishers, 1998. El capítulo I (ps. 25/48) está destinado a MAQUIAVELO de quien afirma que "todo su pensamiento político se orientó constantemente hacia la razón de Estado" y que "si bien no creó la locución creó la cosa".
} 
consideran a su vez imperativas cuando tales exigencias no están en peligro ${ }^{55}$. "El Estado es como un mal perdedor que a veces modifica las reglas del juego" ${ }^{56}$. El secreto, la mentira, el ocultamiento o la simulación -entre otras prácticas pues mencionamos aquí las vinculadas con el propósito de nuestra investigación- son algunos de sus instrumentos. De allí que la doctrina de la razón de Estado se halle asociada a la de los secretos de Estado ${ }^{57}$.

\section{El Estado liberal.}

Tras la crisis y caída del llamado Estado absoluto surgió el denominado Estado liberal. La aparición del liberalismo político cambió las concepciones vigentes y a partir de allí fue posible pensar la razón individual por encima de la razón de Estado. Con esta perspectiva apareció un nuevo tipo de relación entre el poder político y la información que originó una forma específica de publicidad política: la llamada publicidad burguesa expresada en la crítica ilustrada ${ }^{58}$.

La lógica de la razón -y, con ella, la del secreto de Estadoemprendió la retirada y bajo la doctrina liberal se potenció la exigencia de hacer pública la actuación del Estado. El conocido principio absolutista, que en la fórmula hobbesiana se sintetiza en la expresión auctoritas non veritas facit legem, mutará hasta convertirse en veritas non auctoritas facit jus ${ }^{59}$.

La doctrina liberal se consagró, entonces, como el principal fundamento de la crítica ilustrada. Su referente clásico, John LOCKE, concibió la condición del Estado limitado en el que las libertades de los individuos funcionan como diques frente al poder político, el cual, es estrictamente representativo de la voluntad de los ciudadanos. En su concepción "quien tiene en sus manos el poder legislativo o supremo de un Estado, hállase en la obligación de gobernar mediante leyes fijas y establecidas, promulgadas y

\footnotetext{
${ }^{55}$ PIStone, Sergio, voz Razón de Estado, en BobBio, Norberto, MATTEUCCI, Nicola y PASQUino, Gianfranco, Diccionario de Política, México, Siglo XXI, 2008, tomo II, p. 1337.

${ }^{56}$ FeRnández García, Eusebio, Entre la Razón de Estado y el Estado de Derecho, Madrid, Dykinson, 1997, p. 2.

${ }^{57}$ ZARKA, Yves C., voz Raison d'Etat, cit., p. 612.

${ }^{58}$ HABERMAS, Jürgen, Historia y crítica de la opinión pública, trad. Antoni Domènech, 2da ed., Barcelona, GG MassMedia, 1981, p. 124 y siguientes.

${ }^{59}$ FERRAJOLI, Luigi, "Pasado y futuro del estado de derecho", en "Revista Internacional de Filosofía Política", № 17 (2001), p. 31.
} 
conocidas por el pueblo"60. Para el liberalismo, el poder político no tiene un interés propio y sólo se justifica si se garantiza la libertad y la propiedad de cada individuo. Por tanto, el Estado se concibe como un mal necesario cuyo ámbito de acción debe ser claro, preciso y acotado. Su actuar debe ser transparente, visible a los ojos de los ciudadanos. Así, el Estado transparente se traduce en un derecho fundamental del ciudadano a informarse o estar enterado de los cursos de la acción estatal. Entonces, parece claro reconocer en esta tradición la raíz de la idea de publicidad política, sobre todo, en su registro regulativo del poder político.

Los escritos de KANT sobre el principio de publicidad suministran una estructura teórica. El examen de la formulación kantiana requiere una lectura que excede con mucho las páginas de su escrito de 1795 sobre La paz perpetua, en las que se encuentra enunciado. En realidad, hay que remontarse a la Crítica de la razón pura -cuya primera edición aparece en 1781- para encontrar los supuestos teóricos sobre los que se va a edificar tal principio, y para esto también es preciso recorrer los escritos menores de los años 1784 Idea de una historia universal en sentido cosmopolita y ¿Que es Ilustración? (1786); ¿Que significa orientarse en el pensamiento? y Comienzo presunto de la historia humana (1796); Sobre el refrán: Esto puede ser verdad en teoría, pero no en la práctica (1796); El anuncio de la conclusión inminente de un tratado de paz perpetua en filosofía (1797) y Sobre un pretendido derecho de mentir por humanidad (1797) ${ }^{61}$. En el apéndice del primero de ellos $^{62}$ condenó el secreto de los actos de gobierno y abogó por su publicidad. Su pensamiento se halla condensado en esta fórmula:

"Todas las acciones referentes al derecho de otros hombres, cuya máxima no es compatible con la publicidad, son injustas" ${ }^{63}$. Y explica: "una máxima que no puedo manifestar en alta voz, que ha de permanecer secreta, so pena de hacer fracasar mi propósito; una máxima que no puede reconocer públicamente sin provocar en el acto la oposición de todos a mi proyecto; una

\footnotetext{
${ }^{60}$ LOCKE, John, Two Treatises of Government, Cambridge, Cambridge University Press, 2003, $\& 131$, p. 353.

${ }^{61}$ Seguimos el estudio de DE LUCAS, Javier, "Anotaciones sobre el principio kantiano de publicidad", en "Diánoia", volumen 33, $\mathrm{n}^{\circ} 33$ (1987), p. 131 y siguientes y a GosSERIES, Axel la voz Publicity, en Stanford Encyclopedia of Philosophy, puntos 1.1. y 1.4. (Fall 2010 Edition), Edward N. ZALTA (Editor).

${ }^{62}$ Se trata -como se dijo- de La paz perpetua, traducción de F. Rivera Pastor, novena edición, Espasa Calpe, Madrid, 1997.

${ }^{63}$ La paz perpetua, cit., p. 151.
} 
máxima que, de ser conocida, suscitaría contra mí una enemistad necesaria y universal y, por tanto, cognoscible a priori; una máxima que tiene tales consecuencias las tiene forzosamente porque encierra una amenaza injusta al derecho de los demás".

Aunque esta formulación -según se ha observado- parece difícil, se refiere en realidad a una cuestión muy sencilla. En efecto, para KANT la manera más segura de saber si son justas o injustas una intención política, una ley o una decisión de un gobernante, es sacándolas del secreto y poniéndolas a la vista de la opinión pública. Sólo discutiendo abiertamente acerca de la naturaleza de estas acciones políticas, sólo dando razones frente a un público capaz de evaluar, dudar, discutir, criticar y proponer, es que se construye un argumento genuinamente público y se prueba la validez de lo propuesto $^{64}$. La formulación kantiana del problema deriva permite advertir que la obligación de la publicidad de los actos de gobierno es importante no sólo, como se dice, para permitir al ciudadano conocer las acciones de quien detenta el poder y en consecuencia de controlarlas, sino también porque "la publicidad constituye ya de por sí una forma de control, es un expediente que permite distinguir lo que es lícito de lo que no lo es"65.

\section{SOBRE LA MENTIRA POLÍTICA}

1. Las negaciones al principio de publicidad toman distintas modalidades. En rigor, a veces bajo el común denominador de secreto se reúnen con frecuencia manifestaciones que van desde el silencio más hermético en su máxima concentración, al silenció negativo o simple rechazo de los pedidos ciudadanos dirigidos de saber hasta, finalmente, las figuras de la mentira, la simulación o el enmascaramiento.

Un recorrido por los textos clásicos y contemporáneos muestra que el secreto y el engaño han convocado a los pensadores de todos los tiempos. Las páginas precedentes han intentado mostrarlo. Pero, en rigor, se trata de "dos fenómenos diferentes, aunque estén estrechamente

\footnotetext{
${ }^{64}$ RodRíguez ZEPEDA, Jesús, op. cit, p. 39.

${ }^{65}$ BoBBIO, Norberto, El futuro de la democracia, cit., p. 37.
} 
vinculados: el fenómeno del poder oculto o que se oculta y el del poder que oculta, es decir, que se esconde escondiendo". "El primero comprende el tema clásico del secreto de Estado, el segundo abarca el tema igualmente clásico de la mentira lícita y útil (es lícita porque es útil) que nada menos remonta a PLATÓN"66.

Este último planteó la cuestión de las mentiras necesarias ${ }^{67}$ que ha dado origen a lo que se conoce en el terreno de la filosofía política como la doctrina de la noble mentira ${ }^{68}$. Con palabras de un conocido pasaje de su obra:

“¿Cómo nos ingeniaríamos para hacer creer una noble mentira a los gobernantes, en primer término, o, por lo menos, a los demás ciudadanos?" (III, 414, c). Antes afirmaba: "Porque si no nos hemos equivocado hace un momento, si la mentira es realmente inútil para los dioses pero puede ser útil para los hombres como una especie de remedio, es evidente que tal remedio debe ser prescripto por los médicos, y que los profanos no habrán de utilizarlo" (III, 389, b). Concluía así: "Será, pues, lícito el ejercicio de la mentira a los gobernantes de la ciudad, quienes podrán utilizarla para engañar a los enemigos o a los ciudadanos, en beneficio de la ciudad misma; nadie más podrá emplear la mentira" (III, 389, b, in fine $)^{69}$.

Ésta resurge en el siglo XVI con los influyentes trabajos de MAQUIAVELO ${ }^{70}$. Una discusión no saldada disputa sobre el carácter descriptivo o prescriptivo de sus escritos, en tanto algunos consideran que el autor no recomendaba la mentira del gobernante, sino que se limitaba a describir los procedimientos por los cuales se conserva de hecho el poder. En un diálogo imaginario entre MAQUIAVELO y MONTESQUIEU, Maurice JOLY le hace reconocer al primero que su "único crimen fue decir la verdad a los pueblos como a los reyes; no la verdad moral, sino la verdad política; no la verdad como debería ser, sino como es, como será siempre. No soy yo el fundador de la doctrina cuya paternidad me atribuyen; es el corazón del hombre. El maquiavelismo es

\footnotetext{
${ }^{66}$ BoBBIO, Norberto, El futuro de la democracia, cit., p. 105.

${ }^{67}$ PLATON, en República, III, 414, c.

${ }^{68}$ CATAlÁn González, Miguel, "Genealogía de la noble mentira", Amnis. Revue de Civilisation Contemporaine de l'Université de Bretagne Occidentale, 2004, vol. IV, pp. 257-273.

${ }^{69}$ República, cit., p. 228 y p. 192.

${ }^{70}$ En El Príncipe (1513) -su obra más conocida- pero también en la no menos importante Discursos sobre la primera década de Tito Livio (1519).
} 
anterior a Maquiavelo"71. Pero como nada puede sustituir la experiencia de lectura que el estudioso de la filosofía política recibe al abrir El Príncipe, y, ciertamente, nadie podría explicarlo mejor de lo que se explica él ${ }^{72}$, reproducimos un difundido párrafo del capítulo XVIII que dice así:

Cualquiera puede comprender lo loable que resulta en un príncipe mantener la palabra dada y vivir con integridad y no con astucia; no obstante, la experiencia de nuestros tiempos demuestra que los príncipes que han hecho grandes cosas son los que han dado poca importancia a su palabra y han sabido embaucar la mente de los hombres con su astucia, y al final han superado a los que han actuado con lealtad.

Por consiguiente, puesto que el príncipe necesita saber utilizar provechosamente al animal, tiene que elegir entre todos los animales al zorro y al león, porque el león no se sabe defender de las redes y el zorro no se puede defender de los lobos. Así, pues, hay que ser un zorro para conocer las trampas, y un león para amedrentar a los lobos. Los que sólo se basan en el león no entiende de política. Por, tanto un señor que actúa con prudencia no puede ni debe observar la palabra dada cuando vea que va a volverse en su contra y que ya no existen las razones que motivaron su promesa. $Y$ si todos los hombres fuesen buenos, este precepto no sería justo; pero puesto que son malvados y no mantendrían su palabra contigo, tú no tienes que mantenerla con ellos. Y a un príncipe nunca le han faltado razones legítimas para excusar su inobservancia. De ello se podrían presentar infinitos ejemplos modernos y demostrar cuántas paces y cuántas promesas han sido rotas por la infidelidad de los príncipes; y los que han sabido hacer mejor uso del zorro son los que han tenido más éxito. Pero esta cualidad hay que saberla ocultar, y ser hábil fingiendo y disimulando; los hombres son tan ingenuos y responden tanto a la necesidad del momento, que quien engaña siempre encuentra a alguien que se deja engañar ${ }^{73}$.

En 1778 se registra un acontecimiento extraordinario para el pensamiento político. La Academia Prusiana de las Ciencias y las Letras convocó a un curioso concurso académico para debatir la cuestión relativa a la conveniencia para el pueblo de ser engañado. El evento se realizó bajo el patrocinio de FEDERICO II conocido el Grande (1712-1786), quien alrededor de

\footnotetext{
${ }^{71}$ Diálogo en el infierno entre Maquiavelo y Montesquieu, trad. de Luis Rutiaga, México, Grupo Editorial Tomo, 2009, p. 12.

${ }^{72}$ GRÜNER, Eduardo "La astucia del león y la fuerza del zorro. Maquiavelo, entre la verdad de la política y la política de la verdad" en Borón, Atilio A. (Comp.), La filosofía política clásica. De la Antigüedad al Renacimiento, Buenos Aires, Clacso-Eudeba, 1999, capítulo VIII, p. 178.

${ }^{73}$ Empleamos la traducción de Eli LEONETTI JUNGL, Barcelona, Espasa-Calpe, 1995. La cita en la p. 120. Énfasis añadido.
} 
1738 siendo aún Príncipe había tomado partido en la discusión al escribir un ensayo conocido como El Antimaquiavelo y destinado a refutar al "maestro de tiranos" como calificaba a MAQUIAVELO. El texto fue corregido, editado y prologado por VOLTAIRE en dos oportunidades, también bajo el título de Ensayo de crítica sobre el Príncipe de Maquiavelo. Alli FEDERICO Il afirmaba:

He considerado siempre El Príncipe de Maquiavelo como una de las obras más peligrosas que se hayan extendido por el mundo. Es un libro que se le debe caer espontáneamente de las manos a los príncipes y a todos aquellos que gusten de algún modo de la política". En el Capítulo XVIII añade: "Si se quisiera prestar probidad y buen sentido a los confusos pensamientos de Maquiavelo, he aquí cómo poco más o menos se los podría dar vuelta. El mundo es como un juego en el que se encuentran jugadores honestos pero también bribones; para que un Príncipe, que debe jugar en esta partida, no sea engañado en ella, es preciso que sepa de qué manera, se hacen trampas en el juego no para de que él practique jamás semejantes lecciones, sino para que no sea víctima de los otros ${ }^{74}$.

El reinado de FEDERICO II se caracterizó por sus políticas culturales y por sus con inquietudes académicas y artísticas. Fue apodado el rey filósofo y atrajo a su corte a intelectuales y artistas de la talla de VOLTAIRE y $\mathrm{BACH}$. No resulta extraño entonces que fuera D'AlEMBERT -el autor del Discurso Preliminar de la Enciclopedia- quien le sugiriera al rey el tema del concurso que, bajo la forma de una interrogación, fue el siguiente: “¿Es conveniente engañar al pueblo, sea induciéndolo a nuevos errores o manteniéndole en los que ya se encuentra?". En lo que constituye un temprano dato estadístico para la ciencia política, es pertinente recordar que de las treinta y tres contribuciones aceptadas, trece se pronunciaron en sentido afirmativo y veinte en sentido negativo. El jurado acordó repartir el premio entre los dos mejores ensayos representativos de una y otra postura ${ }^{75}$. CONDORCET también autor de varios artículos de la Enciclopedia francesa- se interesó por la convocatoria pero decidió no presentar su trabajo. Fruto de esa preocupación

\footnotetext{
${ }^{74}$ Antimaquiavelo o Refutación del Príncipe de Maquiavelo, trad. Roberto R. ARAMAYO, Madrid, Centro de Estudios Constitucionales, 1995, p. 10 y Las citas corresponden al capítulo XVIII.

${ }^{75}$ Véase CROCKER, Lester Gilbert en "The Problem of Truth and Falsehood in the Age of Enlightenment" en "Journal of the History of Ideas" volumen 14, № 4, p. 575 y, en especial, p. 596/600.
} 
escribió un ensayo titulado Réflexions critiques sur cette question: S'il est utile aux hommes d'être trompés? ${ }^{76}$ cuyas páginas finales expresan ${ }^{77}$ :

"Podemos concluir aquí, en general, que la verdad siempre es útil para el pueblo y que si el pueblo tiene errores es útil para él librarle de los mismos". Y añadía: "Hay muy pocos casos en los que sea útil callar la verdad y alguno en que se puede ser útil disfrazarla".

2. En la reflexión contemporánea se destaca el trabajo de Hannah ARENDT Verdad y política 78 . "Nadie ha dudado jamás que la verdad y la política nunca se llevaron demasiado bien y nadie, por lo que yo sé, puso nunca la veracidad entre las virtudes políticas. Siempre se vio a la mentira como una herramienta necesaria y justificable no sólo para la actividad de los políticos y los demagogos sino también para la del hombre de Estado". Estas son las palabras con las que comienza el difundido escrito.

No duda en vindicar a la mentira: "Las mentiras, que a menudo sustituyen a medios más violentos, bien pueden merecer la consideración de herramientas relativamente inocuas en el arsenal de la acción política" ${ }^{79}$.

Distingue la mentira política tradicional de la reescritura moderna de la historia. Para no traicionar su pensamiento emplearemos sus propias palabras: "La mentira política tradicional, tan saliente en la historia de la diplomacia y de la habilidad política, generalmente se refería a secretos auténticos -datos que nunca se había hecho públicos- o bien a intenciones que, de todos modos, no poseen el mismo grado de certidumbre que los hechos consumados". "Las mentiras políticas modernas tratan eficazmente de cosas que de ningún modo son secretas, sino conocidas prácticamente por todo el mundo. Esto es evidente en el caso de la reescritura de la historia contemporánea a la vista de aquellos que han sido sus testigos". Y concluye en

\footnotetext{
${ }^{76}$ En la versión en español consultada, ¿Es conveniente engañar al pueblo?, trad. de Javier DE LUCAS, Madrid, Sequitur, 2009.

${ }_{78}^{7}$ Op. cit. p. 84 y 85 . Énfasis añadido.

${ }^{78}$ La versión original se publicó en inglés en bajo el título de "Truth and Politics" en la revista "New Yorker" del 25-2-1967. Empleamos la aparecida en The Portable Hannah Arendt, New York, Penguin Books, 2000. La cita corresponde a la p. 545.

${ }^{79}$ Op. cit., p. 546.
} 
estos términos: "la diferencia entre la mentira tradicional y la moderna a menudo equivale a la diferencia entre esconder y destruir"80.

3. Tiempo después, Jacques DERRIDÁ retoma el trabajo de ARENDT con una visión crítica ${ }^{81}$ en la que alternativamente se acerca y se distancia de sus opiniones. Nos interesa señalar que el autor vincula el secreto con la democracia. Descree que la transparencia democrática sea un rasgo positivo. Por el contrario, considera que una cuota de secreto debería ser una garantía frente a los totalitarismos. Una sociedad sin secretos, o también una sociedad en la que todos dijesen en todo momento la verdad, sería irrespirable o imposible, como si la extrema transparencia atentara contra la singularidad y la libertad de sus miembros ${ }^{82}$.

DERRIDÁ subraya la importancia de otro texto -a su juiciotan o más relevante que el de ARENDT. Se trata de del trabajo de Alexandre KOYRÉ cuyas primeras líneas dicen ${ }^{83}$ :

"Nunca se mintió tanto como en nuestros días. Ni de una manera tan desvergonzada, sistemática y constante. Se nos dirá, quizás, que no es así, que la mentira es tan vieja como el mundo, o, al menos, como el hombre, mendax $a b$ initio; que la mentira política nació con la ciudad misma, tal como nos enseña la historia de manera más que abundante; por último, sin remontar el curso de las épocas, se nos dirá que la propaganda falsa de la Primera guerra mundial y la mentira electoral de la época que siguió a esta guerra, alcanzaron niveles y establecieron marcas que serán muy difíciles de superar". Y agrega: "Sin duda, todo esto es verdad. O casi. Es cierto que el hombre se define por la palabra, que ésta acarrea la posibilidad de la mentira y que ella no disgusta a Porfirio: el mentir, mucho más que el reír, es lo propio del hombre. Es cierto, igualmente, que la mentira política es de todos los tiempos, que las reglas y la técnica de lo que hace mucho se llamaba demagogia $y$ en nuestros días propaganda fueron sistematizadas y codificadas hace miles de años; y que los productos de estas técnicas, la propaganda de los imperios olvidados y vueltos polvo nos hablan, todavía hoy". "Es irrefutable que el hombre siempre ha mentido. A sí mismo. A los otros. Por placer, el placer de ejercer esta facultad asombrosa de decir lo que no es y de crear, con su palabra, un mundo del cual es su único responsable y autor.

\footnotetext{
${ }^{80}$ Op. cit., ps. 564 y 565.

${ }^{81}$ Historia de la mentira. Prolegómenos, Buenos Aires, EUFyL, 2015.

82 "Sobre la mentira en política", entrevista a Jacques DERRIDA de Antoine SPIRE en Staccato, programa televisivo de France Culturel, del 7 de enero de 1999; traducción de Cristina DE PERETTI y Francisco VIDARTE. DERRIDÁ subraya la importancia de otro texto -a su juicio- tan o más relevante que el de ARENDT.

${ }^{83}$ Reflexiones sobre la mentira, Buenos Aires, Leviatán, 2004 (edición bilingüe). La cita corresponde a la p. 17. Énfasis añadido.
} 
Ha mentido también para defenderse: la mentira es un arma. El arma preferida del inferior y del débil que, engañando al adversario, se afirma y se venga de él".

4. Un acontecimiento contemporáneo de enorme repercusión no debe omitirse en este punto. Se trata del affaire WATERGATE que involucró al presidente estadounidense Richard NIXON que primero ocultó y luego falseó información con relación a un asalto que habían sufrido, en junio de 1972, unas oficinas del Partido Demócrata, que para entonces era la oposición. Ello desencadenó en su renuncia en 1974, tras protagonizar un desgastante escándalo nacional que se prolongó durante dos años y que lo colocó frente al juicio político cuando la Suprema Corte le exigió la entrega de las grabaciones oficiales de las conversaciones que mantenía con sus secretarios y demás colaboradores en la Casa Blanca. De la vastísima literatura que generó ${ }^{84}$ destacamos un texto que refleja una situación que el transcurso del tiempo no ha modificado:

"A causa del secreto oficial en escala sin precedentes en nuestra historia, la capacidad del gobierno para distorsionar la información a fin de preservar su propio poder político es casi ilimitada". "De manera creciente en los últimos años ha usado la alquimia del poder para preparar verdades sintéticas y conformar nuestra percepción de los acontecimientos con el designio de adecuarlos a determinada política". "Si la información es poder, la habilidad para distorsionarla y controlarla será usada muy a menudo para preservar y perpetuar ese poder". "La excusa para justificar el secreto y la impostura dada por quienes están en el poder consiste en que el pueblo americano a veces debe ser engañado a fin de engañar al enemigo. La justificación es inaceptable según los fundamentos morales y filosóficos, y a menudo simplemente no es verdadera. No pocas veces el enemigo sabe lo que ocurre mejor que el pueblo americano" ${ }^{85}$.

5. La mentira en la vida política es reconocida o tolerada pero -al menos en términos generales- no elogiada. En la vida privada la mentira es -también con dichos límites- reprobada. Ahora bien, del mismo modo, si no más, que lo es en la vida privada, el engaño, la mentira, son reprobables en la vida pública. El tema ha inquietado a los pensadores de

\footnotetext{
${ }^{84}$ Una síntesis y el apoyo documental puede consultarse en KUTLER, Stanley I. Watergate: a brief history with documents, 2da. ed., New York, Wiley-Blackwell, 2010.

${ }^{85}$ WISE, David, The Politics of Lying, New York, Random House, 1973, p. 343 (existe traducción al español, bajo el título La política de la mentira en E.E.U.U., Buenos Aires, La Pléyade, 1976. La cita corresponde a la p. 436).
} 
todos los tiempos -la larga lista de los textos considerados imprescindibles comprende desde Hipias menor de PLATÓN, De mendacio y Contra mendacium de SAn Agustín a Sobre los mentirosos de Montalgne y Sobre un supuesto derecho a mentir por amor a la humanidad de KANT- pero la cuestión requiere trazar múltiples matices que nos llevarían demasiado lejos, contrariando los propósitos de este apartado ${ }^{86}$.

\section{RECAPITULACIÓN}

Con propósito de síntesis, en el cierre de este capítulo, nos interesa destacar que la transparencia en los asuntos del Estado no es una suerte de moda académica o plan partidario en vísperas de elecciones. Constituye un tema que tiene una larga trayectoria intelectual en el pensamiento clásico. El secreto ha acompañado el funcionamiento de los gobiernos desde épocas remotas. Los ha acompañado sin reparar en su origen, autocrático o democrático. Y no los ha abandonado hasta el presente.

El término público como la mayor parte de los conceptos políticos relevantes está lejos de una definición inequívoca. En este trabajo lo público se contrapone a lo oculto, esto es, lo público es lo no secreto. El principio de publicidad recoge básicamente esta acepción.

Un breve repaso histórico permite ver que la doctrina de los arcana imperii y, luego, la de la razón de Estado justificaron la exclusión del principio de publicidad. Pero la aparición del Estado liberal aspiró a superar definitivamente dicha doctrinas.

Los trabajos de KANT constituyen una importante estructura teórica del principio de publicidad y la base para las discusiones que en los siglos siguientes -según se verá en el próximo capítulo- se fueron planteando.

Finalmente hemos procurado advertir con el auxilio de los trabajos de ARENDT y DERRIDÁ -aunque sin ingresar en su desarrollo- que el denominado secreto de Estado difiere de la mentira aunque se hallan

\footnotetext{
${ }^{86}$ Una síntesis de los problemas filosóficos de la mentira puede verse en la obra de Franca D'Agostinı, Mentira, trad. Ana Miravalles, Buenos Aires, Adriana Hidalgo Editora, 2014. Uno de los estudios más completos es la obra de BoK, Sissela, Lying. Moral choice in public and private life, New York, Vintage Books, 1979.
} 
emparentados y constituyen, según muestra la historia, dos recursos frecuentemente empleados de manera conjunta. 


\section{CAPÍTULO II \\ EL SECRETO DE ESTADO EN LA DEMOCRACIA CONTEMPORÁNEA}

\section{INTRODUCCIÓN}

1. El debate sobre la publicidad y el secreto, por cierto, no termina con KANT que, por otra parte, fue testigo de los acontecimientos de la Revolución francesa. Su posición aparece manifestada en uno de sus últimos escritos, publicado en 1798 y titulado Si el género humano se halla en

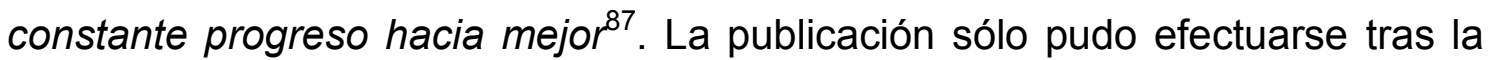
muerte de FEDERICO GUILLERMO II, cuando se eliminaron algunas restricciones a la libertad de prensa. La prohibición había nacido del carácter apologético de la Revolución francesa. Se refiere a ésta como "la revolución de un pueblo lleno de espiritualidad" que, a pesar de haber acumulado miserias y crueldad como para inducir a un hombre bien intencionado a no intentar el experimento una segunda vez, sin embargo ha encontrado en los espíritus de los espectadores una participación de aspiraciones que alcanza el entusiasmo, definido como "participación en el bien con pasión, que se refiere siempre y solamente a aquello que es ideal, a lo que es puramente moral" y no puede tener otra causa que "una disposición moral del género humano". La tesis kantiana consiste en que es que tal disposición moral se manifiesta en la afirmación del derecho un derecho natural- que tiene el pueblo de no ser impedido por otras fuerzas a darse una Constitución civil que él cree buena. Esta Constitución no puede ser para KANT sino la republicana, es decir, aquella cuya bondad consiste en ser la única Constitución capaz de evitar por principio la guerra ${ }^{88}$.

2. Con la Revolución francesa en el siglo XVIII, la burguesía no renuncia a ejercer el control sobre los actos de gobierno y por ello combate los secretos de estado, los arcana imperii, la censura, etc, a fin de lograr el máximo de publicidad ${ }^{89}$. Estas ideas se potenciaron y fueron paulatinamente consagradas por las constituciones que, a partir del siglo XIX,

${ }^{87}$ Se trata del libro El conflicto de las facultades, trad. de Elsa TABERNIG, Buenos Aires, Losada, 2004.

${ }^{88}$ El conflicto de las facultades, cit. ps. 117 y 118.

${ }^{89}$ MATEUCCI, Nicola, voz Opinión pública en Diccionario de política, cit., tomo II, p. 1076. 
se fueron sancionando en distintos países. A ambos lados del Atlántico, los Estados Unidos de América y Francia encabezaron este movimiento.

En 1787 la Constitución de los Estados Unidos de Norteamérica ya disponía que "cada Cámara llevará un diario de sus sesiones y lo publicará de tiempo en tiempo a excepción de aquellas partes que a su juicio exijan reserva" y "ninguna cantidad podrá extraerse del tesoro si no es como consecuencia de asignaciones autorizadas por la ley, y de tiempo en tiempo deberá publicarse un estado y cuenta ordenados de los ingresos y gastos del tesoro" (art. 1, 5ta. y 9na. Sección). Y en la Constitución francesa de 1791 se disponía que "las deliberaciones del Cuerpo legislativo serán públicas y las actas de las sesiones se imprimirán" (Título III, capítulo III, sección $2^{\mathrm{a}}$, art. $1^{\circ}$ ).

Su influencia se hizo sentir también en América Latina y, naturalmente, en la Argentina. En la Constitución mexicana se consagra el principio de máxima publicidad de los actos de gobierno (art. 6, A.I.). La Constitución de Costa Rica establece: "Se garantiza el libre acceso a los departamentos administrativos con propósitos de información sobre asuntos de interés público. Quedan a salvo los secretos de Estado" (art. 30). La primera Constitución de la República Oriental del Uruguay, con estilo llano establecía: "El Presidente debe publicar y circular, sin demora, todas las Leyes" (art. 82). La Constitución de Ecuador ordena que "la Presidenta o Presidente de la República promulgará la ley y se publicará en el Registro Oficial” (art. 137). La Constitución de Paraguay ordena que el Poder Ejecutivo "dispondrá su publicación dentro de los cinco días" (art. 204). En la Argentina el texto constitucional lacónicamente pone en cabeza del Poder Ejecutivo "hacer publicar" (art. 99 inc. $3^{\circ}$ ).

Una visión general de ese movimiento constituyente permite dar cuenta de la consolidación de las ideas que propiciaban la ampliación de la publicidad y la reducción del secreto. Hay que atravesar aún todo el siglo XIX y aguardar el fin de la Segunda Guerra, para registrar una nueva etapa del constitucionalismo que encuentra expresión en la Constitución italiana de 1947 y en la alemana de 1949. La primera dice que: "las leyes se publicarán inmediatamente después de su promulgación y entrarán en vigor el decimoquinto día tras su publicación, a menos que en las mismas se 
establezca un plazo distinto" (art. 73). La Ley Fundamental germana (Grundgesetz) establece que "todos tienen el derecho a [...] informarse sin trabas en las fuentes accesibles a todos" (art. 5, párrafo 1); que las leyes entran en vigencia tras su publicación en el Boletín de Leyes de la Federación (art. 82, párrafo 2) y que "las reuniones del Parlamento Federal serán públicas" (art. 42, párrafo 1).

Tras una pausa de tres décadas este movimiento constituyente cobra nuevas fuerzas. Primero con las constituciones Portugal (1976) y de España (1978). Aquella consagra el principio de publicidad de los actos y expresamente prevé que su omisión "implica la ausencia de efectos jurídicos" (art. 119), y ésta, encomienda al Rey que tras la intervención de las Cortes ordene la "inmediata publicación" (art. 91). Luego de la caída de la Unión de Repúblicas Socialistas Soviéticas, en Europa del Este se dispara una nueva etapa en la que se sancionan textos constitucionales que combinan los principios democráticos occidentales con tradiciones propias como en los casos de las constituciones de Croacia (1990), Rumania (1991), Bulgaria (1991), Albania (1998), etc. En todas ellas se enfatiza el principio de publicidad, probablemente como una reacción al secretismo que imperó en los sistemas que venían a desplazar ${ }^{90}$. En América Latina las constituciones de Venezuela (1999), Ecuador (2008), Bolivia (2009) -aun innovando en algunos aspectosmantienen los principios clásicos de publicidad de los actos de gobierno ${ }^{91}$.

3. Pero, además, desde mediados del siglo $X X$ el pensamiento político registra efectúa importantes contribuciones sobre el concepto de lo público y, entre las muchas -la enumeración es inevitablemente parcial $^{92}$ - no pueden omitirse los trabajos de Reinhart KosELLECK, Hannah ARENDT y HABERMAS cuyas líneas fundamentales trazaremos en lo que sigue.

\footnotetext{
90 HÄBERLE, Peter, "Avances constitucionales en Europa Oriental desde el punto de vista de la jurisprudencia y de la teoría constitucional" en "Pensamiento Constitucional" (Perú), vol. $2, N^{\circ} 2$ (1995), p. 141, en especial p. 155, nota 28.

91 GaRGARELLA, Roberto, "El nuevo constitucionalismo latinoamericano", en "Estudios Sociales" No 48 (primer semestre 2015), p. 169 muestra las continuidades y rupturas con los textos anteriores.

92 Precisamente y en razón de la importancia de sus aportaciones, en el libro ya citado de Nora RABOTNIKOF, la autora examina el concepto de lo público a la luz del pensamiento de KANT, KOSELLECK, ARENDT, HABERMAS y LUHMANN. La literatura en la materia focaliza, en general, en dichos autores. Así, por ejemplo, NAVARRo DíAZ, Luis R., Entre esferas públicas y ciudadanía. Las teorías de Arendt, Habermas y Mouffe aplicadas a la comunicación para el cambio social,
} 
a) En su libro Crítica y crisis: un estudio sobre la patogénesis del mundo burgués KOSELLECK afirma que a partir de las guerras de religión de la segunda mitad del siglo XVI lo público se identifica con la autoridad del poder absoluto, y en cambio, lo privado es el espacio dominado por la fe y por la conciencia individual. Relegar los valores éticos y las creencias religiosos al espacio privado hizo que la res publica fuera dominada por el poder del Estado, lo que promovió a su vez que el individuo dividiera sus ámbitos de acción en ambas esferas. En este período, el Estado se constituyó como instancia suprarreligiosa, por encima de las divisiones entre estamentos y de poderes locales. Sin embargo, su funcionamiento no se hizo visible. Se acudió al secretismo, se escondió de manera general el arte del gobierno, entre otras cuestiones, por lo no pertinente de difundir determinadas acciones discrecionales. Por ello se hizo imprescindible legitimar la división entre un espacio abierto a la político que debería ser dominado por esta instancia y uno dedicado a la expansión de la moralidad. La originalidad de la perspectiva propuesta por KOSELLECK - según se ha observado ${ }^{93}$ - consiste en pensar la producción de lo privado como el resultado, a la vez, de la quiebra de la cristiandad y de la afirmación de la racionalidad propia al ejercicio absoluto del poder monárquico. Por lo tanto, sitúa en la segunda mitad del siglo XVI la construcción de la dicotomía que divide a cada individuo y las raíces del proceso que, dos siglos después, instaurará el reino de la crítica. La contraposición entre lo público y lo secreto le sirve a KOSELLECK Como hilo conductor para explicar el tránsito del absolutismo a la llustración y su culminación en la Revolución Francesa. Afirma que desde los comienzos, la llustración y el secreto aparecieron como gemelos históricos (historical twins) ${ }^{94}$. En textos posteriores, vuelve sobre el tema: "Los límites entre secreto y publicidad son mucho más permeables en las democracias occidentales, y su

Barranquilla, Ediciones Uninorte, 2010 y SAHUIS, Alejandro, Razón y espacio público: Arendt, Habermas y Rawls, México, Ediciones Coyoacán, 2002.

${ }^{93}$ CHARTIER, Roger, "Lo privado y lo público Construcción histórica de una dicotomía" en "Coherencia: Revista de Humanidades", Año 2007, v. 4 Nº 7, la cita en la p. 71.

94 Hemos consultado la versión inglesa, Critique and Crisis: Enlightenment and the Pathogenesis of Modern Society, Cambridge, Massachusetts, The MIT Press, 1988, capítulo 5, p. 62 y siguientes. 
determinación posibilita una elasticidad que se corrige mutuamente, aunque favorece también una relativa lentitud del actuar" $"$.

b) ARENDT en La condición humana, reconstruye las nociones de lo privado y lo público-político siguiendo la oposición griega entre oikos y polis. El ámbito doméstico -oikos- se encuentra sujeto a la satisfacción de las necesidades de la vida e implica, consecuentemente, un proceso cíclico en constante repetición. En el oikos, entonces, no es posible la libertad puesto que sus miembros están sometidos al yugo de la necesidad y establecen entre sí relaciones asimétricas de mando y obediencia. En la polis, en cambio, los ciudadanos se reconocen como iguales para el tratamiento de los asuntos comunes. Por eso, la noción de gobierno, que supone una desigualdad entre quienes mandan y quienes obedecen, es propia del oikos y resulta ajena a la polis en donde sería más apropiado hablar de isonomía entendida como la igualdad entre los ciudadanos para participar activamente en los asuntos públicos de la asamblea ${ }^{96}$. "La palabra público significa dos fenómenos estrechamente relacionados, si bien no idénticos por completo. En primer lugar significa que todo lo que aparece en público puede verlo y oírlo todo el mundo y tiene la más amplia publicidad posible". En segundo lugar "público significa el propio mundo, en cuanto es común a todos nosotros y diferenciado de nuestro lugar poseído privadamente por él. Este mundo, sin embargo, no es idéntico a la Tierra o a la naturaleza" sino que "está relacionado con los objetos fabricados por la mano del hombre, así como con los asuntos de quienes habitan juntos en el mundo hecho por el hombre". Más adelante afirma: "La publicidad de la esfera pública es lo que puede absorber y hacer brillar a través de los siglos cualquier cosa que los hombres quieran salvar de la natural ruina del tiempo"97.

En trabajos posteriores su pensamiento se afina sobre el punto pues considera que no todo espacio público es inmediatamente un espacio político: "el espacio público sólo llega a ser político cuando se establece en una ciudad, cuando se liga a un sitio concreto que sobreviva tanto a las gestas memorables como a los nombres de sus autores, y los transmita a

${ }^{95}$ Koselleck, Reinhart y GadAmeR, Hans-Georg, Historia y hermenéutica, trad. Faustino ONCINA, Barcelona, 1997, p. 79.

${ }_{96}$ La condición humana, trad. Ramón GIL NovALES, Buenos Aires, Paidós, 2009, p. 37.

${ }^{97}$ Ibidem, p. 59, 61 y 62. 
la posteridad en la sucesión de las generaciones. Esta ciudad, que ofrece un lugar permanente a los mortales y a sus actos y palabras fugaces; es la polis, políticamente distinta de otros asentamientos (para los que los griegos también tenían una palabra) en que sólo ella se construye en torno al espacio público, la plaza del mercado, donde en adelante los libres e iguales pueden siempre encontrarse" ${ }^{\prime \prime 8}$.

c) Desde los inicios de su obra, HABERMAS se interesó por la investigación sobre el espacio público y la opinión pública. Historia y crítica de la opinión pública apareció en 1962 y en ella dialoga con los trabajos de ARENDT. Luego desarrolló su teoría de la acción comunicativa, en la que presenta la discusión pública como la única posibilidad de superar los conflictos sociales, gracias a la búsqueda de consensos que permitan el acuerdo y la cooperación a pesar de los disensos. Más tarde, en Facticidad y validez lleva a cabo una investigación sobre la relación entre hechos sociales, normatividad y política democrática; el espacio público se presenta como el lugar de surgimiento de la opinión pública, que puede ser manipulada y deformada, pero que constituye el eje de la cohesión social, de la construcción y legitimación (o deslegitimación) política. Las libertades individuales y políticas dependen de la dinámica que se suscite en dicho espacio público. "Hablamos de espacio público político, distinguiéndolo del literario, cuando las discusiones públicas tienen que ver con objetos que dependen de la praxis del estado. El poder del estado es también el contratante del espacio público político, pero no su parte. Ciertamente, rige como poder público, pero ante todo necesita el atributo de la publicidad para su tarea, lo público, es decir, cuidar del bien general de todos los sujetos de derecho. Precisamente, cuando el ejercicio del dominio político se subordina efectivamente a la demanda pública democrática, logra el espacio público político una influencia institucional en el gobierno por la vía del cuerpo legislativo. El título opinión pública tiene que ver con tareas de crítica y de control, que el público de los ciudadanos de un estado ejercen de manera

\footnotetext{
98 ¿Qué es política?, trad. Rosa SALA CARBÓ, Barcelona, Paidós, 1997. La cita en la p. 74. Énfasis añadido.
} 
informal (y también de manera formal en las elecciones periódicas) frente al dominio estatalmente organizado" $"$.

d) Foucault es autor de una extensa obra en la que realiza estudios críticos de las instituciones sociales, en especial la psiquiatría, la medicina, el sistema de prisiones, la historia de la sexualidad humana ${ }^{100}$. Sus trabajos sobre el poder y las vinculaciones entre poder, conocimiento y discurso ha sido ampliamente debatidos. FOUCAULT rompe con las concepciones clásicas de este término. Para él, el poder no puede ser localizado en una institución, o en el Estado, está determinado por el juego de saberes que respaldan la dominación de unos individuos sobre otros al interior de estas estructuras. El poder no es considerado como algo que el individuo cede al soberano (contractualismo) sino que es una relación de fuerzas, una situación estratégica en una sociedad determinada. Por lo tanto, el poder, al ser relación, está en todas partes, el sujeto está atravesado por relaciones de poder, no puede ser considerado independientemente de ellas. El poder no sólo reprime sino que también, produce efectos de verdad y produce saber.

A su juicio no debe considerarse "el poder como un fenómeno de dominación macizo y homogéneo" como la "dominación de un individuo sobre los otros, de un grupo sobre los otros, de una clase sobre las otras". El poder, salvo si se lo considera desde muy arriba y muy lejos "no es algo que se reparte entre quienes lo tienen y lo poseen en exclusividad y quienes no lo tienen y lo sufren. El poder, creo, debe analizarse como algo que circula o, mejor, como algo que sólo funciona en cadena. Nunca se localiza aquí o allá, nunca está en las manos de algunos, nunca se apropia como una riqueza o un bien. El poder funciona. El poder se ejerce en red y, en ella, los individuos no sólo circulan, sino que están siempre en situación de sufrirlo y también de ejercerlo. Nunca son el blanco inerte o consintiente del poder,

\footnotetext{
${ }^{99}$ El párrafo pertenece a la obra Kultur und kritik. Empleamos la traducción y publicación de uno de sus capítulos, bajo el título de "La esfera de lo público" en Francisco GALVÁN Díaz (comp.), Ensayos de teoría social, México, UAP/UAM Azcapotzalco, 1986, pp. 51-61.

100 Historia de la locura en la época clásica (1961), El nacimiento de la clínica (1963), Las palabras y las cosas: una arqueología de las ciencias humanas (1966), La arqueología del saber (1969), Vigilar y castigar (1975), Historia de la sexualidad (1976-1984), entre las más relevantes.
} 
siempre son sus relevos. En otras palabras, el poder transita transversalmente, no está quieto en los individuos" ${ }^{101}$.

Y al analizar el poder en otras de sus obras, en apariencia alejada del tema que examinamos en este trabajo - se trata del primer volumen de Historia de la sexualidad publicado en 1976- formula una interesante contribución a nuestra materia. En efecto, allí afirma que "el poder es tolerable sólo con la condición de enmascarar una parte importante de sí mismo" y que "su éxito está en proporción directa con lo que logra esconder de sus mecanismos". Y añade: "para el poder, el secreto no pertenece al orden del abuso; es indispensable para su funcionamiento" ${ }^{102}$.

4. Nuestro enfoque, como señalamos en el capítulo anterior, impone una limitación al objeto de estudio. Está orientado a examinar lo público en uno de sus sentidos: como contrario a lo oculto, es decir, lo público como lo no secreto. O, en otros términos: "lo que es visible y se desarrolla a la luz del día, lo manifiesto y ostensible contra aquello que es secreto, reservado, oculto: lo que no puede verse, aquello de lo que no puede hablarse, que se sustrae a la comunicación y al examen, históricamente vinculado con lo sacro, accesible sólo al saber de los iniciados" ${ }^{103}$. Y en esta dirección indagaremos la necesidad o la conveniencia del secreto y, luego, su extensión en un sistema democrático.

\section{EL SECRETO Y LA PUBLICIDAD: UNA CUESTIÓN DE LÍMITES}

No es infrecuente encontrar afirmaciones terminantes respecto de la necesidad de avanzar hacia una transparencia absoluta en el ámbito de la actividad estatal ${ }^{104}$. La supresión o eliminación del secreto constituiría el instrumento para alcanzarla. Pero, ciertas reflexiones colocan en entredicho esta última afirmación. Habría un núcleo inderogable de secreto,

\footnotetext{
${ }^{101}$ Defender la sociedad. Curso en el Collège de France (1975-1976), Buenos Aires, Fondo de Cultura Económica, 2001, p. 38; publicado también en Microfísica del poder, trad. de Julia VARELA y Fernando ÁlVAREZ-URía, Madrid, Ediciones de La Piqueta, 1980, p. 144.

${ }^{102}$ Historia de la sexualidad, trad. de Ulises GuIÑAZÚ, 30ma ed., Buenos Aires, Siglo XXI Editores, 2005, tomo I, p. 105.

${ }_{103}$ RABOTNIKOF, Nora, El espacio público y la democracia moderna, cit, p. 18.

${ }^{104}$ En nuestro propio proceso de investigación nos hallábamos cercanos a esa idea, que luego fue encontrando reparos que desarrollamos en el texto.
} 
necesario o útil. Los trabajos de Georg SIMMEL ${ }^{105}$ sobre la sociología del secreto -en nuestra opinión- son muy relevantes y contribuyen -si se nos tolera el neologismo- a desdemonizar el secreto y a comprender su función. Las páginas que siguen procurarán sintetizar sus ideas sobre el tema.

1. La sociología de la mentira y del secreto.

La filosofía del dinero coloca a SIMMEL en una dimensión teórica comparable con MARX, WEBER y DURKHEIM ${ }^{106}$ pero constituye un ejemplo atípico de su producción académica. Su obra sobre el secreto -alguno de cuyos aspectos vamos a examinar en lo que sigue- lo muestra como un gran estudioso de los asuntos sociales de escala reducida. Tal como se ha señalado, a SIMMEL le gusta "colocar a la sociedad bajo el microscopio, constantemente fascinado por lo pequeño y lo íntimo"107.

Ninguno de sus trabajos ofrece una oportunidad mejor para apreciar su peculiar análisis de la sociedad que su difundido estudio sobre el secreto. "Lo que hace DURKHEIM con el suicidio lo hace SIMMEL - de una manera diferente, pero vinculada a aquella -con el secreto; es decir, lo extrae del reducto del individuo que lo guarda y lo coloca directamente entre las relaciones y procesos de la sociedad. El suicidio y el secreto, cada cual a su modo, son la esencia de todo aquello que corresponde a lo más recóndito de la

\footnotetext{
${ }^{105}$ Nació en Berlín en 1858 y estudió en la Universidad de dicha ciudad en dónde alcanzó el grado de doctor con una tesis sobre la filosofía de KANT. Junto con Max WEBER y Ferdinand TONNIES fundó la Sociedad Alemana de Sociología. Murió en 1918. Fue el primer alemán en impartir cursos universitarios de sociología y lo hizo, en forma ininterrumpida, desde 1893 hasta el final de sus días. Abordó el estudio de objetos hasta ese momento insospechados de ser tratados por la sociología: el secreto, la amistad, el amor, los encantos de objetos, como el perfume o el adorno, la condición de extranjería, la hospitalidad y la hostilidad, la fidelidad y la gratitud, la dominación y la libertad, el movimiento político de las mujeres, los problemas para la organización del socialismo y el anarquismo, y muchos otros, que aborda con gran naturalidad. Desarrolló una teoría más compleja y sofisticada que lo que habitualmente se supone. Algunos autores reconocen cuatro niveles básicos de preocupación en su obra: a) la perspectiva microscópica de la vida social; b) el análisis de los componentes sociológicos de las relaciones interpersonales; c) la perspectiva macroscópica y d) la perspectiva filosófica. Los datos biográficos son recogidos de la cronología efectuada por Esteban VERNIK en el prefacio a la obra de SIMMEL, Cuestiones fundamentales de sociología, traducción de Ángela ACKERMANN PILÁRI, Barcelona, Gedisa, 2002. Para la trayectoria de su pensamiento, consúltese RITZER, George, Teoría sociológica clásica, traducción de María Teresa CASADO RODRÍGUEZ, Madrid, McGraw-Hill, 1993, p. 301.

${ }^{106}$ RITZER, George, op. cit., p. 325.

${ }^{107}$ NISBET, Robert, La formación del pensamiento sociológico, traducción de Enrique MoLINA DE VEDIA, segunda edición, Buenos Aires, Amorrortu, 2009, tomo I, 138.
} 
motivación individual y, sin embargo, sólo resultan comprensibles en su relación con la sociedad" ${ }^{108}$.

La sociología del secreto y de las sociedades secretas. Éste es el título del artículo en el que SIMMEL examina la cuestión ${ }^{109}$. Parte de un hecho básico: las personas deben saber algunas cosas sobre las demás con el fin de interactuar con ellas. El comerciante sabe que su proveedor quiere comprar barato y vender caro; el maestro sabe que puede suponer cierta calidad y cantidad de conocimiento de sus alumnos; en fin, las personas, en general, saben en cada clase social, qué conocimientos pueden tener sus semejantes. Sin ese conocimiento no podría tener lugar ninguna interacción entre los individuos. "El saber con quién se trata es la primera condición para tener trato con alguien". Pero se trata de un conocimiento fragmentario pues "nunca se puede conocer a otro en absoluto" pero no obstante "con los fragmentos que observamos, formamos una unidad personal" ${ }^{110}$.

Conocidos, amigos, esposas y esposos. A partir de allí SIMMEL distingue diversas relaciones sociales en las que varían, en intensidad, aquello que se conoce y oculta al otro. Analiza la situación en el conocido, en la amistad y en el matrimonio.

"El grado de conocimiento que supone el ser conocidos no se refiere a lo que el otro es en sí, no a lo que es en su interior, sino en aquella parte que manifiesta a los demás". Por ello, aquí opera la discreción. Esta no consiste "sólo en respetar el secreto del otro" sino también "en evitar conocer del otro lo que él positivamente no nos revele". Pero la discreción también reconoce grados y variará "según las diversas personas a que se refiere".

La amistad, desde esta perspectiva, despierta en SIMMEL una actitud más optimista que respecto -como se verá- al matrimonio. Cuando "la entrega no es tan apasionada, pero tampoco tan desigual, puede servir mejor para vincular por entero a las personas; puede abrir las puertas del alma de un modo menos intenso, pero en mayor extensión y continuidad".

\footnotetext{
${ }_{108}^{108}$ NISBET, Robert, op. cit., p. 143.

109 "The Sociology of Secrecy and of Secret Societies", publicado en la revista "American Journal of Sociology", volumen 11, $n^{\circ} 4$ (Enero, 1906), p. 441-498. La traducción del alemán al inglés -al igual que muchos de sus otros trabajos- fue realizada por Albion W. SMALL pero registra pasajes de difícil comprensión. Hemos empleado también una traducción efectuada por Kurt H. WolfF que aparece en el libro The Sociology of Georg Simmel, Illinois, The Free Press, 1950, p. 307 y siguientes. Las referencias se harán, en lo sucesivo, a esta versión.

110 Ibidem, p. 307 y 308.
} 
Considera que menos en la juventud, en la actualidad se entablan amistades diferenciadas. Unas provienen de la cercanía afectiva, otras de la laboral, otras de la religiosa, etc. y así se determina el "grado de comunicación o reserva que debe haber".

En el matrimonio -conjetura- "es fácil ceder en los primeros tiempos a la tentación de sumirse completamente uno en otro, de vaciar las últimas reservas del alma tras las del cuerpo, de perderse totalmente uno en otro. Pero esta conducta amenaza seriamente, en la mayoría de los casos, el futuro de la relación". Por ello y para que los matrimonios no perezcan sugiere practicar también aquí la discreción.

En definitiva, mujeres y hombres "estamos hechos de tal manera, que no sólo necesitamos, como se indicó antes, una determinada proporción de verdad y error como base de nuestra vida, sino también una mezcla de claridad y oscuridad, en la percepción de nuestros elementos vitales" $" 11$.

Sobre las mentiras. "Nada de lo que digamos si excede de la interjección o del minimun de comunicación, expresa, de modo inmediato y fiel, lo que pasa en nosotros durante un tiempo determinado, sino que es una transformación de la realidad en un sentido teleológico, abreviado y sintético". Si ello no fuera así -alerta SIMMEL- terminaríamos en un manicomio.

La mentira juega un papel social relevante. Por ello señala que "las estructuras sociológicas se distinguen de un modo característico, según el grado de mentira que alienta en ellas". Distingue la situación del "hombre primitivo" y de las "civilizaciones más ricas y amplias" y sostiene que los efectos son más catastróficos en la sociedad actual. "La mentira en la vida moderna es algo más nocivo que antes y pone más en peligro los fundamentos de la vida". "Nuestra vida moderna en mucho mayor extensión que lo que suele pensarse descansa sobre la creencia en la honradez de los demás, desde la economía que es cada vez más economía de crédito, hasta el cultivo de la ciencia, en donde los investigadores, en su mayoría, tienen que usar resultados hallados por otros y que ellos mismos no pueden verificar" ${ }^{\text {"112. }}$.

\footnotetext{
111 Ibidem, p. 320, 320, 321, 322, 325, 326, 328 у 329.

112 Ibidem, p. 312 y 313.
} 
Sobre el secreto. Hay en las palabras de SIMMEL cierto elogio del secreto. Constituye -dice- "una de las más grandes conquistas de la humanidad". "Comparado con el estado infantil en que toda representación es comunicada en seguida, en que toda empresa es visible para todas las miradas, el secreto significa una enorme ampliación de la vida, porque en completa publicidad muchas manifestaciones de ésta no podrían llevarse a cabo" ${ }^{113}$.

"Una de las características de toda relación entre dos personas o entre dos grupos es el haber o no haber en ella secreto y la medida en que lo hay". $Y$ alerta que no debe repararse en el sentido negativo que moralmente se le atribuye generalmente al secreto. "El secreto es una forma sociológica general, que se mantiene neutral por encima del valor de sus contenidos"114. Es, más breve aún, "una técnica sociológica".

Así como en otra clase de relaciones SIMMEL hablaba de la discreción, ahora habla de traición. "El secreto contiene una tensión, que se resuelve en el momento de la revelación". El secreto "pone una barrera entre los hombres; pero, al propio tiempo, la tentación de romper esa barrera".

El contenido del secreto es variable. $\mathrm{Y}$ así "lo que originariamente era público se torna secreto y lo que originariamente era secreto, levanta sus velos". Pero, aunque parezca paradójico, la convivencia humana "exige una misma cantidad de secreto, variando tan sólo los contenidos de éste". SIMMEL pasa revista a la historia y encuentra que en la democracia de su tiempo se considera "la publicidad como un estado deseable en sí mismo, partiendo de la idea fundamental de que todos deben conocer los sucesos y circunstancias que les interesan, pues es esta la condición previa para participar en su decisión". Y remata con estos términos: "lo público se hace cada vez más público; lo privado, cada vez más privado"115.

2. El secreto en la vida democrática.

La lectura de los textos de SIMMEL permite encontrar ideas sobre múltiples temas: el conocimiento recíproco entre los individuos en

\footnotetext{
${ }^{113}$ Ibidem, p. 330.

${ }^{114}$ Si bien reconoce que "el secreto no está en conexión con el mal, el mal está en conexión con el secreto".

115 Ibidem, p. 332, 333, 334, 335 y 337.
} 
general, entre conocidos, amigos y esposos; la discreción y la traición; la mentira y el secreto. Pero en medio de ellas, surgen otras igualmente sugerentes que permiten repensar el tema que aquí nos convoca, esto es, la tensión entre publicidad y secreto en la vida democrática.

$$
\text { El derecho a buscar información. "En general, el }
$$

hombre se atribuye derecho a saber todo cuando pueda averiguar, sin recurrir a medios externos ilegales, por observaciones y reflexiones psicológicas" ${ }^{116}$. Escrita hace más de cien años constituye una proposición de incuestionable actualidad aunque todavía no se han disipado las dificultades de interpretación de la segunda parte de su formulación. En este orden de ideas, un conflicto frecuente consiste en determinar cuáles de aquellos medios externos pueden reputarse legales o ilegales ${ }^{117}$. Pero en el debate contemporáneo la discusión se vincula con el conflicto que provoca, por un lado, la necesidad de obtener información en democracias representativas y, por otro, la lógica mercantilista de los medios de comunicación. Sin dudas, ello constituye uno de los más serios problemas para la consolidación democrática, que aquí sólo puede ser enunciado $^{118}$.

La denominada economía de crédito y la información. La estructura de la vida moderna se asienta en la economía de crédito, entendida en un sentido mucho más amplio que el puramente económico ${ }^{119}$. Debemos frente a innumerables encrucijadas- confiar sin posibilidad de comprobar; en fin, admitir lo dado de buena fe. En la actividad económica o en la actividad académica -que son los ejemplos que emplea el autor- es indispensable dar crédito a cierta información suministrada por otros. Sus reflexiones tienen un carácter pionero, según se ha observado ${ }^{120}$, para la sociología económica.

\footnotetext{
116 Ibidem, p. 323.

${ }^{117}$ Estos casos quedan confinados a asuntos de interés predominantemente individual. Por ejemplo, la observación de personas u objetos en la vía pública sería un caso inobjetable de modo legítimo de alcanzar el conocimiento. Pero, seguramente, no podría afirmarse lo mismo si se obtuviesen imágenes a través del uso de teleobjetivos empleados desde un avión o helicóptero que sobrevolara una propiedad privada o de otros instrumentos con tecnologías más sofisticadas.

${ }^{118}$ La desnuda descripción de este fenómeno y su crítica puede verse en CHOMSKY, Noam, Necessary Illusions Thought Control in Democratic Societies, London, Pluto Press, 1989, capítulo 1 , p. 9 y siguientes.

119 Ibidem, p. 313.

${ }^{120}$ HeRRANZ GonZÁlez, Roberto, "Georg Simmel y la sociología económica: el mercado, las formas sociales y el análisis estratégico", "Papers: Revista de Sociologia”, 2008, № 87, p. 269286.
} 
Para él la confianza se sitúa en un campo medio entre el conocimiento absoluto y la ignorancia. "El que sabe -sentencia- no necesita confiar, el que ignora no puede siquiera confiar"121.

La democracia y la información. "La democracia considera la publicidad como un estado deseable en sí mismo, partiendo de la idea fundamental de que todos deben conocer los sucesos y circunstancias que les interesan, pues es esta la condición previa para participar en su decisión".

SIMMEL no estigmatiza al secreto. No lo moraliza. Lo acepta. Lo considera una técnica sociológica que, como tal, se mantiene inmutable a lo largo de la vida social. Y aunque él refiere que no varía en cantidad sino en contenido, uno de los desafíos actuales consiste en determinar cuánto y cuáles secretos son tolerables para que un sistema pueda considerarse democrático.

El propio autor, cuando recorre la historia, constata las variaciones según las épocas. Mientras en los siglos XVII y XVIII, por ejemplo, el número de soldados y la situación de los impuestos se ocultaba -a punto que averiguarlo constituía una de las principales misiones de los embajadoresen el siglo siguiente "los gobiernos publican oficialmente los datos que hasta entonces todo régimen debía mantener secretos si quería mantenerse" ${ }^{122}$.

\section{EL SECRETO DEMOCRÁTICO}

La tesis de SIMMEL señala que la transparencia absoluta entre mujeres y hombres conduciría al manicomio y que, por ello, el secreto es "una de las más grandes conquistas de la humanidad" ${ }^{123}$. Siguiendo su metáfora, el interrogante a disipar en las próximas páginas consiste en determinar cuál sería el destino de un Estado democrático sin secretos. A tal fin acudiremos a algunos conceptos sobre la democracia y luego procuraremos responder si un sistema democrático de gobierno admite la existencia de secretos y, en su caso, a qué requisitos se hallan sujeto.

\footnotetext{
${ }^{121}$ The Sociology of Georg Simmel, cit., p. 318.

122 Ibidem, p. 337 y 336.

${ }^{123}$ The Sociology of Georg Simmel, cit., p. 330.
} 
1. Sobre los conceptos de democracia.

1. Si definir la democracia es explicar qué significa el vocablo -dice SARTORI- "el problema se resuelve rápido; basta saber un poco de griego. La palabra significa, literalmente, poder (kratos) del pueblo (demos). Mas de esta manera habremos resuelto sólo un problema de etimología: únicamente se ha explicado el nombre". "El problema -alerta- es mucho más complejo" ${ }^{124}$, afirmación cuyo acierto se advierte apenas se examine la inabarcable literatura que existe sobre el tema. Si el estudio se confinara a las clases o variantes de democracia, habría que enfrentarse con la democracia ateniense, constitucional, cristiana, deliberativa, directa, liberal, maximalista, minimalista, participativa, popular, procedimental, realista, representativa, resultadista, semidirecta, social, etc.

Nada de esto es posible en este trabajo y nos limitaremos a presentar los conceptos desarrollados por BOBBIO y DAHL que no escogimos azarosamente. En efecto, el primero ha dedicado parte de su producción académica a examinar la democracia pero también la ha vinculado $y$ profundizado con estudios referidos al secreto y a la publicidad en la vida del Estado. Dicho de modo aún más simple, ha asociado con singular énfasis la democracia y la transparencia. El segundo, porque propone una definición realista que incluye pormenores útiles para nuestra investigación y porque el término poliarquía permite diferenciar la democracia política de otras formas y ámbitos de la democracia ${ }^{125}$.

2. Aunque en el capítulo anterior hemos esbozado la cuestión, volvemos sobre el punto para alcanzar mayor claridad en la exposición. En efecto, entre las múltiples definiciones de la democracia ${ }^{126}$, Bоввіо ofrece una que pone precisamente de relieve la importancia de esta cuestión, y es de esa noción de la que vamos a partir por cuanto, además, permite advertir con la mayor claridad la ambivalencia del principio de publicidad. Como antes expusimos, el autor afirma que la democracia no sería

\footnotetext{
${ }^{124}$ SARTORI, Giovanni, ¿Qué es la democracia?, trad. González Rodríguez y Pestellini Laparelli Salomon, Buenos Aires, Taurus, 2003, p. 21.

${ }^{125}$ O'DonNeLL, Guillermo, Disonancias. Críticas democráticas a la democracia, Buenos Aires, Prometeo, 2007 p. 32.

126 "La democracia se puede definir de las más diversas formas, pero no hay definición de la misma que pueda dejar de lado la inclusión, entre sus características de la visibilidad o transparencia del poder", sentencia Bоввıо. Véase El futuro de la democracia, cit., p. 41.
} 
otra cosa sino el gobierno del poder visible, el gobierno del poder público en público, donde se reúnen ambas acepciones de lo público, la que se contrapone a lo privado y aquella otra que es el antónimo de lo secreto.

En realidad, como se ha señalado ${ }^{127}$, la definición no importa una novedad. En este orden de ideas es pertinente recordar las ideas de James MADISON ${ }^{128}$ volcada en una misiva: "Un gobierno del pueblo, en la ausencia de toda información del pueblo o de los medios que le permiten acceder a ella, no es más que el prólogo de una farsa o de una tragedia, es decir, de una tragicomedia. El conocimiento le llevará siempre por encima de la ignorancia. Un pueblo que quiere ser su propio soberano debe procurarse el poder que le facilita el conocimiento" ${ }^{129}$.

3. DAHL ${ }^{130}$ afirma que "la poliarquía ${ }^{131}$ es un régimen político que se distingue, en el plano más general, por dos amplias características: la ciudadanía es extendida a una proporción comparativamente alta de adultos, y entre los derechos de la ciudadanía se incluye el de oponerse a los altos funcionarios del gobierno y hacerlos abandonar sus cargos mediante el voto".

De modo más concreto afirma que "es un orden político que se singulariza por la presencia de siete instituciones, todas ${ }^{132}$ las cuales deben estar presentes para que sea posible clasificar a un gobierno como poliárquico".

\footnotetext{
${ }^{127}$ DE LUCAS MARTíN, Francisco Javier, "Democracia y transparencia: Sobre poder, secreto y publicidad" en "Anuario de filosofía del derecho" (Sociedad Española de Filosofía Jurídica y Política), № 7 (1990), p. 131. La cita corresponde a la p. 134.

${ }^{128}$ La ciencia política en los Estados Unidos de Norteamérica, habla de democracia madisoniana, atribuyéndole el nombre de uno de sus padres fundadores. DAHL, Robert A., $A$ Preface to Democratic Theory, Chicago, The University of Chicago Press, 2006, p. 4 y siguientes.

${ }_{129}$ Se trata de la carta que le remitió a W. T. BARRY - un militar con actividad política en el Estado de Kentucky- el 4 de agosto de 1822. Véase The Founders' Constitution, volume 1, chapter 18, document 35, press-pubs.uchicago.edu/founders/documents/v1ch18s35.html.

130 On democracy, cit., p. 85.

131 Ibidem, p. 90.

132 O'DONNELL agrega otros requisitos. Los funcionarios electos (y algunas personas designadas, tales como los jueces que conforman los tribunales superiores) no deben ser arbitrariamente desplazados de sus cargos antes del término constitucional de sus mandatos. Los funcionarios electos no deben estar sujetos a restricciones severas, vetos o exclusión de ciertas esferas políticas por otros actores no electores, en especial las fuerzas armadas. Y, debe existir un territorio no cuestionado que defina claramente la población en condiciones de votar. Véase op. cit., p. 152, nota 4.
} 
El autor prefiere reservar el término democracia para un sistema político ideal -probablemente, inalcanzable- donde exista una perfecta o casi perfecta igualdad de poder y, habla, en cambio de poliarquía, es decir, del gobierno de muchos pero no de todos, cuando se trata de referirse a regímenes concretos. En un apartado de su trabajo titulado Palabras sobre palabras explica:

Poliarquía se deriva de las palabras griegas que significan muchos y gobierno; se distingue así el gobierno de los muchos del gobierno de uno o monarquía, o del gobierno de los pocos, aristocracia u oligarquía. A pesar de que dicho término apenas había sido usado, un colega y yo lo introdujimos en 1953 como una adecuada forma para referirnos a una democracia representativa moderna con sufragio universal. A partir de ahora lo utilizaré en este sentido. Más específicamente, una democracia poliárquica es un sistema político dotado de las seis -a la luz de trabajos posteriores pueden considerarse siete como lo afirmamos en el texto- instituciones democráticas contenidas en la lista de arriba. La democracia poliárquica es, pues, distinta de la democracia representativa con sufragio restringido, como la del siglo XIX. Es también diferente a las democracias y repúblicas más antiguas, que no sólo tenían sufragio restringido, sino que carecían de muchos de las otras características cruciales de la democracia poliárquica, tales como partidos políticos, derecho a formar organizaciones políticas para influir en a oponerse a los gobiernos existentes, grupos de interés organizados, etcétera. Es también distinta de las prácticas democráticas propias de unidades tan pequeñas que permiten el establecimiento de una asamblea directa de sus miembros y su decisión (o recomendación) directa de las políticas o leyes.

La democracia según DAHL exige:

1. Funcionarios electos. El control de las decisiones en materia de política pública corresponde, según lo establece la constitución del país, a funcionarios electos.

2. Elecciones libres e imparciales. Dichos funcionarios son elegidos mediante el voto en elecciones limpias, que se llevan a cabo con regularidad y en las cuales rara vez se emplea la coacción.

3. Sufragio inclusivo. Prácticamente todos los adultos tienen derecho a votar en la elección de los funcionarios públicos.

4. Derecho a ocupar cargos públicos. Prácticamente todos los adultos tienen derecho a ocupar cargos públicos en el gobierno. 
5. Libertad de expresión. Los ciudadanos tienen derecho a expresarse, sin correr peligro de sufrir castigos severos, en cuestiones políticas definidas con amplitud, incluida la crítica a los funcionarios públicos, el gobierno, el régimen, el sistema socioeconómico y la ideología prevaleciente.

6. Variedad de fuentes de información. Los ciudadanos tienen derecho a procurarse diversas fuentes de información, que no sólo existen sino que están protegidas por la ley.

7. Autonomía asociativa. Para propender a la obtención o defensa de sus derechos (incluidos los ya mencionados), los ciudadanos gozan también del derecho de constituir asociaciones u organizaciones relativamente independientes, entre ellas partidos políticos y grupos de intereses.

Resulta claro, entonces, que si los ciudadanos enfrentan vacíos y lagunas de información sobre asuntos públicos, difícilmente tendrán oportunidad de formar y expresar genuinamente sus opiniones sobre dichos asuntos. Ello socava los principios fundamentales de toda democracia: el control popular y la igualdad política. $\mathrm{O}$, expresado de otro modo, si conforme a estos criterios, las autoridades de manera deliberada retienen, retrasan 0 manipulan la información pública para evitar que la ciudadanía pueda participar libre y objetivamente en la formación de la voluntad general, la calidad de la vida democrática se resiente gravemente.

\section{El secreto democrático.}

1. Dos observaciones iniciales. En primer lugar, "calificar un caso como democrático o no -explica O'DONNELL- no es sólo un ejercicio académico: tiene consecuencias morales, en la medida en que en la mayor parte del mundo contemporáneo hay consenso en cuanto a que la democracia, no importa lo que este concepto signifique para cada uno, es la forma de gobierno normativamente preferible" ${ }^{\text {"133. }}$.

La restante es la siguiente: aquello que "vale en los asuntos públicos de un régimen democrático, en los que la publicidad es la regla y el secreto la excepción, no vale en los asuntos privados, o sea, cuando está en juego un interés privado. Antes bien, en las relaciones privadas es válido exactamente lo contrario: el secreto es la regla, contra la intromisión de

${ }^{133}$ Véase Disonancias. Críticas democráticas a la democracia, cit., p. 23. 
lo público en lo privado y la publicidad es la excepción. Precisamente porque la democracia presupone la máxima libertad de las personas individualmente consideradas, éstas deben ser protegidas, en su esfera privada, de un control excesivo por parte de los poderes públicos. En suma, está en la lógica misma de la democracia el que la relación entre regla y excepción esté invertida en la esfera pública respecto de la privada"134.

Aunque este esquema se mantiene hay una creciente irrupción de lo público en lo privado. Algunas, claramente inadmisibles, otras más discutibles. Expresado brevemente: no hay dudas que las cuestiones vinculadas con la salud son datos sensibles que no pueden ser divulgados, como por ejemplo, los datos contenidos en una historia clínica. Pero valga este ejemplo histórico para ilustrar esta tensión:

"A comienzos de 1973 dos médicos de reconocida fama llegaron a la conclusión clínica de que el candidato presidencial padecía arteriosclerosis y pericarditis. Si asumía el gobierno, no viviría más de un año. De este hecho estaba informado también otro posible candidato. Los tres personajes resolvieron respetar la intimidad del líder y no hacer pública esta noticia. El $61,85 \%$ de los votantes lo eligió presidente el 23 de septiembre de 1973; el elegido no quiso falsear los pronósticos médicos y murió el $1^{\circ}$ de julio de 1974 . Su esposa asumió la presidencia y este hecho fue uno de los factores desencadenantes de la mayor tragedia de la historia argentina. Los protagonistas de esta historia son los doctores Jorge TAIANA y Pedro CossIO, Héctor CÁMPORA, Juan e Isabel PERÓN” ${ }^{135}$.

En síntesis, el análisis que precede muestra el secreto de Estado como una excepción posible a la regla de la publicidad.

2. Una relevante reflexión sobre el tema ${ }^{136}$ asume que no hay una radical incompatibilidad o enfrentamiento entre la democracia y el secreto. Es más, el secreto en ocasiones puede ser defendido sobre la base de valores democráticos. El dilema -continúa- tiene que ver con la responsabilidad (accountability): "la democracia requiere publicidad pero algunas políticas democráticas requieren secreto".

\footnotetext{
${ }^{134}$ BoBBIO, Norberto, Democracia y secreto, cit., p. 68 y 69.

135 GARZÓN VALDÉZ, Ernesto, "Privacidad y publicidad" en "Doxa" № 21, vol. 1 (1998), p. 223. Décadas después, Francia asistió a un debate debido a la salud -en rigor, al ocultamiento de la enfermedad que padeció durante todo su mandato- del presidente MITTERRAND. La cuestión se originó con la publicación de un libro -Le grand secret- escrito por el médico presidencial, Claude GUBLER, que detallaba la trama del ocultamiento. Véase TIERSKY, Ronald, François Mitterrand: A Very French President, Rowman \& Littlefield, New York, 2003, p. 336, bajo el título de "Mitterrand's last secref".

${ }^{136}$ THOMPSON, Dennis F., "Democratic Secrecy", cit., p. 181.
} 
Mínimamente una democracia exige -como se señaló- que los ciudadanos puedan evaluar la actuación de los gobernantes y para ello resulta indispensable que puedan conocer qué es lo que hacen. Pero hay ámbitos en los que la difusión frustraría la política que se pretende implementar; así, una operación bélica para recuperar un territorio o liberar a personas sojuzgadas o detenidas.

El dilema que se plantea puede encontrar una pronta solución: si la publicidad hace peligrar una política de Estado, ello significa que debe ser abandonada. Pero las democracias contemporáneas, con acierto o sin él, no actúan de esa manera aunque aspiran a limitar el secreto. Dos técnicas pueden aplicarse para alcanzar esa finalidad.

a) Establecer una vigencia temporal del secreto.

Un modo de limitar los efectos del secreto en la vida pública es establecer un marco temporal para su vigencia. Al cabo de ese tiempo debe ser difundido. No se escapa que la extensión asignada a dichos plazos es crucial. Si el conocimiento se adquiriera cuando no puede actuar sobre la responsabilidad de los gobernantes, la difusión no cumpliría los fines democráticos que la inspiran.

b) Afinar el velo que cubre la actividad que se oculta.

Entre la publicidad integral y el secreto absoluto, es posible consagrar soluciones intermedias $\mathrm{y}$, en ese sentido, pueden imponerse difusiones parciales. Por ejemplo, puede trazarse una distinción entre reglas de conducta y reglas de decisión ${ }^{137}$. Una agencia estatal dicta una norma que prohíbe una conducta y dicha norma es difundida con amplitud. Pero la agencia encargada de su aplicación no difunde con la misma intensidad las normas internas para su aplicación. Hay cierta hipocresía o doble personalidad. Si la norma dice que perseguirá y aplicará multas a quienes coloquen en la vía pública desechos domiciliarios fuera del horario establecido, las prácticas internas podrán revelar que la efectiva persecución y sanción se realiza tras la tercera comprobación y, nunca, inmediatamente luego de la primera. Pero dichas prácticas no son objeto de difusión. THOMPSON ilustra con un antiguo ejemplo de BENTHAM esta publicidad menguada: señala que el filósofo no

137 ThOMPSON, Dennis F., Restoring Responsibility Ethics in Government, Business, and Healthcare, p. 135. 
compartía la idea de establecer la pena de muerte por delitos. Pero como buen utilitarista pensaba que la amenaza de la pena capital resultaba necesaria para evitar la comisión de ciertos crímenes. La solución era la siguiente: la ley debía establecer la pena de muerte para ciertos delitos que se ejecutaría haciendo ingerir veneno. El veneno debía ser suministrado al condenado en público y una vez que perdiera el conocimiento debía ser sacado de la vista y se suministraría un antídoto. Al condenado se le notificaría que la revelación de ese secreto, estaba condenada con la pena capital. Esta vez sin antídoto ${ }^{138}$.

3. Es perfectamente posible -para sumar un nuevo ejemplo- que un municipio aprueba una resolución que autoriza la circulación, con fines de control, de vehículos estatales sin la debida identificación. Pero no es objetable que se mantenga en secreto con relación a los recorridos que efectuarán. $O$, que una legislatura debate la instalación de radares para verificar la velocidad de los automóviles en las rutas pero que la ubicación precisa de aquéllos, no se revele.

El secreto se encuentra justificado en ambos casos. Cuando determinados datos o política permanecerán secretos (secreto de primer orden) se requiere la publicidad de la decisión de conservar aquellos datos o política secretos (publicidad de segundo orden). Esto es, retomando los ejemplos, permanecerá oculta la ubicación de los autos y los radares pero se habrá tomado públicamente la decisión de autorizarlos. Este mecanismo permite conciliar -probablemente, no de manera absoluta- la pretensión de eficacia que la política de control implementada requiere mediante el sigilo ${ }^{139}$, con la discusión y publicidad que exige un sistema democrático.

\section{LA RECEPCIÓN DE ESTAS IDEAS EN LA ARGENTINA}

Las ideas que se han expuesto en este capítulo y en el anterior no han permanecido ajenas a los debates que se han ido generando

\footnotetext{
138 ThOMPSON, Dennis F., Restoring Responsibility Ethics in Government, Business, and Healthcare, cit., p. 134.

139 Piénsese en el resultado que arrojaría si en una ruta, sujeta al control mediante radares, se precisara y difundiera su ubicación y rango.
} 
en los distintos momentos históricos desde la Revolución de Mayo, pasando por la Generación del 37 y del 80 y sus continuadores hasta la actualidad.

1. La filosofía francesa del siglo XVIII era conocida por la élite ilustrada de la sociedad colonial en el Río de la Plata así como los principales sucesos políticos de la Revolución Francesa. Desde 1789 a 1804 se había prohibido la circulación en España y en los virreinatos de libros e impresos relacionados con los sucesos de Francia y de los Estados Unidos. Los controles no fueron suficientes y las obras de VOLTAIRE, MONTESQUIEU, ROUSSEAU y otros se encontraban en bibliotecas particulares e incluso podía hallarse la Enciclopedia completa ${ }^{140}$.

Algunos de los integrantes de la Primera Junta de Gobierno instalada el 25 de mayo de 1810- Mariano MoRENo, Manuel BELGRANO, Nicolás RodRíguez PEÑA y Juan José CASTELLI, entre otros- se hallaban fuertemente influenciados por las ideas políticas de la llustración y habían tomado contacto con dichas obras en virtud de sus estudios universitarios en España y en Chuquisaca, el notable centro académico del Alto Perú. Una de las principales obras escritas por los pensadores ilustrados -El contrato social de RousSEAUfue traducida -o hecha traducir- por MORENO ${ }^{141}$ y su publicación dispuesta por la Junta de Gobierno. Ésta la aprobó el 2 de noviembre de 1810 con el objeto de implantar una reforma escolar ${ }^{142}$ :

"Á fin de que se modernize el orden de la enseñanza pública en las escuelas, obteniéndose al efecto permiso del Superior Gobierno para su reimpresión; que el Excelentísimo Cavildo lo repartiese por una vez a los niños pobres de todas las escuelas y que se obligase a los hijos de padres pudientes a que lo compren en la Imprenta..' Asimismo, se ordenó "que se imprima el libro sin pérdida de tiempo con prevención al editor de que ha de entregar a este Cavildo mil ejemplares para hacer la distribución acordada".

\footnotetext{
140 TAU AnzoAtegul, Víctor-MARtiRe, Eduardo, Manual de historia de las instituciones argentinas, 4ta edición, Buenos Aires, Macchi, 1975, p. 284.

${ }^{141}$ Se discute si la traducción le corresponde o la encargó y se limitó a redactar el prólogo. "¿Fue MORENO el traductor de la versión del Contrato Social que la Junta aprobó en 1810, o solamente promovió que se reimprimiera una versión ya existente? La hipótesis de la traducción por MORENO, sostenida entre otros por Raúl ORGAZ, es rechazada por GROUSSAC, FURLONG y Enrique DE GANDíA. La atribución a MORENO de esta versión castellana no es insostenible; el estudiante de Chuquisaca conocía ya perfectamente el francés". Véase el estudio preliminar de Diego TATIAN en RouSSEAU, Jean-Jacques Del contrato social, Córdoba, Universidad Nacional de Córdoba, 2011 (edición facsimilar de la realizada por Mariano MORENO en 1810).

${ }^{142}$ Véase p. 14 de la edición facsimilar citada.
} 
Pero la gravitación de las ideas roussonianas ${ }^{143}$ es más clara -y pertinente a los fines de este trabajo- cuando a pocos días de la conformación de la Primera Junta de Gobierno -el 7 de junio- apareció el primer número de la publicación La Gazeta de Buenos Ayres. Esta publicación ${ }^{144}$ se comportó como el primer periódico de un gobierno patrio y constituye el antecedente del actual Boletín Oficial que es el órgano de publicación de leyes y demás disposiciones del gobierno federal. La orden de la Junta -datada el 2 de junio- expresa en sus fundamentos ${ }^{145}$ :

"Una exacta noticia de los procedimientos de la Junta; una continuada comunicación pública de las medidas que acuerde para consolidar la grande obra que se ha principiado; una sincera y franca manifestación de los estorbos que se oponen al fin de su instalación y de los medios que adopta para allanarlos, son un deber en el Gobierno provisorio que exerce, y un principio pura que el Pueblo no resfríe en su confianza, ó deba culparse así mismo si no auxilia con su energía y avisos á quienes nada pretenden sino sostener con dignidad los derechos del Rey y de la Patria, que se le han confiado. El Pueblo tiene derecho á saber la conducta de sus Representantes, y el honor de estos se interesa en que todos conozcan la execración con que miran aquellas reservas y misterios inventados por el poder para cubrir los delitos".

La trayectoria de la Gazeta de Buenos Ayres finalizó con un decreto del 24 de agosto de 1821 firmado por Bernardino RIVADAVIA que estableció que la organización y publicación un Registro Oficial, para la difusión de todas "las leyes, órdenes y decretos y actos de un efecto general o que demanden una comunicación". Desde entonces y hasta el actual Boletín Oficial se sucedieron modificaciones administrativas o de organización pero se mantiene viva la idea de difundir los actos públicos porque el pueblo tiene derecho a saber.

2. El proceso constituyente que culminó con la sanción de la Constitución Nacional en 1853 no puede desvincularse de las ideas de Juan

\footnotetext{
143 "Junto a la Enciclopedia, a la obra de ROUSSEAU a quien tanto admiraba y a la de otros pensadores franceses, MORENO frecuentó el pensamiento de los autores de la llustración española que ejercieron en él una curioso influencia". ROMERO, José Luis, "Las ideas filosóficas de Moreno" en La experiencia argentina y otros ensayos, Buenos Aires, Editorial de Belgrano, 1980, p. 199.

${ }^{144}$ Su redacción fue encargada a Mariano MoRENO, Manuel BeLgRano y Juan José CASTELLI.

${ }^{145}$ Utilizamos la Gaceta de Buenos Aires (1810-1821), reimpresión facsimilar dirigida por la Junta de Historia y Numismática Americana, Buenos Aires, Compañía Sud-Americana de Billetes de Banco, 1910, p. 16. Énfasis añadido.
} 
Bautista ALBERDI desarrolladas en su libro Bases y puntos de partida para la organización política de la República Argentina. Tal como se ha señalado ningún estudioso responsable niega la influencia directa del tucumano. Solamente se cuestiona la mayor o menor medida de ello ${ }^{146}$ pero éste constituye un enorme debate abierto. El punto aquí reside en destacar la continuada presencia e influencia del pensamiento francés en el suyo. $Y$ en este sentido es claro que tomó los principios políticos de la Revolución francesa y los adoptó sin discusión. La Declaración de los Derechos del Hombre y del Ciudadano fue trasladada a su proyecto de constitución casi al pie de la letra. Agregó luego los principios económicos y sociales pero éstos -especialmenteen función de las necesidades y características temporales y geográficas del país. AlBERDI importa los principios que con vocación universal había proclamado aquélla pero añade las necesidades propias del país: poblarlo, navegar sus ríos, abrir caminos, crear industrias, instruir a sus habitantes ${ }^{147}$.

La filiación del pensamiento alberdiano a las ideas francesas encuentra un expreso reconocimiento del autor, en un elocuente pasaje que dice asi ${ }^{148 .}$

"Nuestras simpatías con la Francia no son sin causa. Nosotros hemos tenido dos existencias en el mundo, una colonial, otra republicana. La primera, nos la dio la España: la segunda, la Francia. El día que dejamos de ser colonos, acabó nuestro parentesco con la España: desde la República, somos hijos de la Francia. Cambiamos la autoridad española por la autoridad francesa, el día que cambiamos la esclavitud por la libertad. A la España le debemos cadenas, a la Francia libertades. Para los que están en los íntimos orígenes históricos de nuestra regeneración, nuestras instituciones democráticas no son sino una parte de la historia de las ideas francesas. El pensamiento francés envuelve y penetra toda nuestra vida Republicana"149.

\footnotetext{
${ }^{146}$ García Mansilla, Manuel José-Ramírez Calvo, Ricardo, Las fuentes de la Constitución Nacional, Buenos Aires, LexisNexis, 2006, p. 40.

${ }^{147}$ GHIRARDI, Olsen A., La filosofía en Alberdi, Córdoba, Academia Nacional de Derecho y Ciencias Sociales de Córdoba, 1993, p. 130 y LACLAU, Martín, "Las influencias filosóficas en el pensamiento de Juan Bautista Alberdi" en "Revista de historia del derecho", Buenos Aires, No 41, p. 139-161 (junio- 2011).

${ }^{148}$ Fragmento preliminar al estudio del derecho, Buenos Aires, Biblos, 1984, p. 153.

${ }^{149}$ En los años posteriores matizó esta admiración -expresada en términos tan absolutosalabando a la cultura anglosajona y en especial a la de los Estados Unidos, en cuya Constitución encontró también fuerte inspiración. Véase ZAFFARONI, Eugenio Raúl, "Alberdi y la vigencia de la Constitución de 1853" en QUATTROCHI-WoISSON, Diana (Directora) Juan Bautista Alberdi y la Independencia argentina. La fuerza del pensamiento y de la escritura, Quilmes, Universidad de Quilmes, 2012, p. 59.
} 
Esa misma fuente se advierte cuando expone su pensamiento sobre las bondades de la publicidad de los actos de gobierno:

"Otro medio de impedir que los delegatarios de la soberanía abusen de su ejercicio en daño del pueblo a quien pertenece, es la publicidad de todos los actos que lo constituyen. La publicidad es la garantía de las garantías. El pueblo debe ser testigo del modo cómo ejercen sus mandatarios la soberanía delegada por él. Con la constitución y la ley en sus manos, él debe llevar cuenta diaria a sus delegados del uso que hace de sus poderes. Tan útil para el gobierno como para el país, la publicidad es el medio de prevenir errores y desmanes peligrosos para ambos. El pueblo debe ver cómo desempeñan sus mandatos los legisladores. Las leyes deben ser hechas a su vista, sancionadas en público"150.

3. En ocasión del centenario de la Revolución de Mayo, Joaquín V. GonZÁLEZ publica El juicio del siglo. En este trabajo ${ }^{151}$ señala que "la prosperidad de la República es obra exclusiva de la Constitución". Antes había dado a la luz el Manual de la Constitución Argentina (1897), libro que como expresa el prólogo estaba dirigido a los alumnos de "los colegios de instrucción secundaria" ${ }^{152}$ en el que explica, con espíritu didáctico, la Constitución. La interpretación que realiza de su articulado se mantiene aún viva en la jurisprudencia actual, esto es, en la aplicación que a diario hacen nuestros tribunales. Tal ha sido su vigor, que la figura de la acción de amparo reconocida por la Corte Suprema mediante una sentencia del año 1957 -y luego consagrada en el artículo 43 de la Constitución Nacional tras la reforma de 1994- encuentra en la opinión del autor al que el tribunal cita extensamente, uno de sus más sólidos fundamentos.

Su concepción sobre la ley fundamental continúa el pensamiento alberdiano. En sus propias palabras ${ }^{153}$ :

“En realidad, la Constitución estaba modelada desde hacía mucho tiempo no sólo en sus cláusulas escritas, sino, lo que es más esencial, en

\footnotetext{
${ }^{150}$ Derecho público provincial, Buenos Aires, Talleres Gráficos Argentinos de L. J. Rosso, 1928, p. 105.

${ }^{151}$ Analizan algunos de sus contenidos, TERÁN, Oscar, Historia de las ideas en la Argentina Diez lecciones iniciales, 1810-1980, Buenos Aires, Siglo XXI, 2008 p. 181 y sigts. y RomERO, José Luis, Las ideas políticas en la Argentina, Buenos Aires, Fondo de Cultura Económica, 1984, p. 200.

152 Manual de la Constitución Argentina, cit., p. 10.

153 Obras completas de Joaquín V. Gónzález, Buenos Aires, Imprenta Mercatali, 1936, tomo 22, p. 18.
} 
su espíritu y tendencias, en los escritos de los pensadores y tribunos de la emigración y de la época anterior a Rosas: ECHEVERRíA, GutiéRREZ, Mitre, Alberdi, SARMiento, Vélez SARSFIELd y otros, que recogieron de la ciencia europea y americana las normas escritas que habían de encauzar las más íntimas aspiraciones sociales y políticas de la nación, las legaron y expresaron de viva voz, y por escrito, en las Asambleas constituyentes de Santa Fe y Buenos Aires, formando la conciencia democrática que precedió a sus sanciones, y definiendo y consignando en la Carta, el espíritu democrático que inspira todo su organismo...".

Joaquín V. GónZÁlEZ es, para algunos, "uno de los más brillantes y completos pensadores y hombres de Estado de nuestra patria" y para otros, "el más logrado estadista después de ALBERDI". Uno de los autores clásicos del derecho constitucional argentino lo llama "el místico de la Constitución" ${ }^{154}$. Y la influencia de sus opiniones en la jurisprudencia contemporánea, efectivamente -más allá del generoso reconocimiento de las virtudes intelectuales y personales que ciertos autores le prodigan- es equiparable a la de ALBERDI. Y es visible que sigue esa huella cuando -en lo que interesa a este trabajo- afirma que "la publicidad es un requisito sustancial de nuestro Gobierno"155.

4. Tras el restablecimiento democrático en 1983, la Argentina ratificó la Convención Americana de Derechos Humanos conocida como Pacto de San José de Costa Rica y en los años siguientes luego de la enmienda constitucional de 1994, se incorporan paulatinamente al derecho interno una serie de convenciones internacionales dirigidas a procurar mayor participación ciudadana y transparencia en los asuntos públicos. Adquirió autonomía el derecho a la información. Las audiencias públicas se convirtieron en una exigencia para las modificaciones de las tarifas de los servicios públicos. Se implementaron los presupuestos participativos, es decir, que en ciertas áreas se destinan partidas para atender pedidos específicos de los ciudadanos. Las leyes de acceso a la información pública comenzaron a sancionarse a nivel local y a exigirse una ordenación integral a nivel federal. Se ratificaron las convenciones internacionales contra la corrupción. Se endurecieron las normas penales internas en los delitos cometidos en el ejercicio de la función

\footnotetext{
${ }^{154}$ LINARES QUINTANA, Segundo V., "Joaquín V. González, el místico de la Constitución”, en "Revista de estudios políticos" (Madrid) No 137 (1964), p. 181.

${ }^{155}$ Manual de la Constitución Argentina, cit., p. 508.
} 
pública y se suspendieron los plazos de prescripción mientras los funcionarios imputados se encuentren en el poder.

La corrupción o la percepción que de ella tiene la población se incorporaron a la discusión pública ${ }^{156}$. La finalización del mandato del presidente MENEM marcó el surgimiento del paradigma de la transparencia ${ }^{157}$. De una visión tradicional ligada a la punición de los delitos y concentrada en las modificaciones y actualizaciones del Código Penal se pasó a una visión primordialmente preventiva. No se trató, por cierto, de un fenómeno de raíz local sino que obedeció a la llamada internacionalización de la lucha contra la corrupción. Los organismos la consideran una amenaza para la gobernanza, el desarrollo sustentable, los procesos democráticos y las prácticas corporativas justas. De allí que abogan por el fortalecimiento y construcción institucional, como la creación de agencias u oficinas anticorrupción; la prevención mediante las declaraciones juradas de los funcionarios y su periódico monitoreo y la difusión del tema del acceso a la información pública y las campañas de concientización de la población ${ }^{158}$.

La tensión entre la publicidad y el secreto estatal es una renovada discusión en la política contemporánea de la Argentina ${ }^{159}$.

\section{RECAPITULACIÓN}

El desarrollo precedente justifica una efectuar una síntesis de puntos relevantes que auxiliará en el examen de los próximos capítulos.

\footnotetext{
${ }^{156}$ RABOTNIKOF, Nora, "Corrupción política: definiciones técnicas y sentidos sedimentados" en "Insomnia" № 10 (México), abril 1999, p. 25.

${ }^{157}$ PeReYRA, Sebastián, Política y transparencia. La corrupción como problema público, Buenos Aires,Siglo XXI, 2013, p. 235. Por oposición, el período anterior fue calificado de fiesta menemista. Véase BONNET, Alberto, La hegemonía menemista. El neoconservadurismo en Argentina, 1989-2001, Buenos Aires, Prometeo, 2007, p. 266.

${ }^{158}$ Ibidem, p. 242.

${ }^{159}$ Bastarán dos rápidas referencias. El Estado se negó a difundir información respecto de la entrega de planes sociales porque -a su juicio- ello estigmatizaba la pobreza. La Corte Suprema no avaló esa posición. La segunda: la empresa Yacimientos Petrolíferos Fiscales se negó a difundir un convenio que había suscripto con una empresa petrolera extranjera (Chevron Corporation). Los jueces tampoco legitimaron el secreto. Véase BASTERRA, Marcela, "Los límites al ejercicio del derecho de acceso a la Información Pública. El caso Chevron", en "Revista de derecho ambiental", Universidad de Palermo (Argentina), vol. 3, No 2 (noviembre 2014), p. 121.
} 
Las ideas de KANT sobre la publicidad de los actos de gobierno y las nacidas con la Revolución francesa ejercieron una notable influencia sobre los textos constitucionales surgidos a fines del siglo XVIII y durante el siglo XIX. La Argentina y otros países de la región, como se vio, consagraron disposiciones que favorecían la publicidad que constituía una exigencia de la vida republicana. Luego, ya en el siglo XX y en los albores del $\mathrm{XXI}$, el constitucionalismo europeo de la postguerra y el neoconstitucionalismo latinoamericano ratificaron y, en ocasiones, perfeccionaron estas ideas.

En el pensamiento contemporáneo constituye un criterio generalmente aceptado que en los asuntos públicos de un régimen democrático la publicidad es la regla y el secreto la excepción. Ello -por ciertono vale en los asuntos privados, o sea, cuando está en juego un interés privado. Antes bien, en las relaciones privadas es válido exactamente lo contrario: el secreto es la regla, contra la intromisión de lo público en lo privado y la publicidad es la excepción. Pero dicha regla no requiere publicidad incondicional de los actos de gobierno. El secreto, en diversos ámbitos, se encuentra justificado e, incluso, es deseable en una democracia. En este último sentido las reflexiones de SIMMEL daban cuenta de que las mujeres y hombres necesitan para vivir en sociedad una mezcla de claridad y oscuridad.

La idea de una publicidad absoluta aparece relegada y cobra vigor la de una publicidad moderada. Esta posición, en ocasiones, se justifica apelando a una expresión que deriva del derecho norteamericano y que ha pasado a la ciencia política: la Constitución no es un pacto suicida que obligue a una difusión ilimitada que conduzca a la autodestrucción ${ }^{160}$. Se admite entonces la existencia de un secreto tolerable, compatible con los valores reconocidos de la vida democrática.

Uno de los modos de limitar las indeseables consecuencias de secreto y de lograr un deseable equilibrio es implementarlo temporalmente o parcialmente. La profundización de la vida democrática exige que "los secretos

\footnotetext{
${ }^{160}$ La expresión aparece en un voto disidente de la Suprema Corte de los Estados Unidos de Norteamérica, en el caso "Terminiello v. City of Chicago", 337 U.S. 1 (1949).
} 
temporales no se conviertan en permanentes y que los parciales no se conviertan en totales"161.

161 Thompson, Dennis F., Restoring Responsibility Ethics in Government, Business, and Healthcare, cit., p. 140. 


\section{CAPÍTULO III \\ LAS LEYES SECRETAS: CONTENIDO Y MOMENTO HISTÓRICO DE LA SANCIÓN DE CADA UNA DE ELLAS}

\section{LA DEROGACIÓN DE LAS LEYES SECRETAS}

La ley 26.134 -cuyo extenso y prolongado debate legislativo examinaremos- es paradójicamente muy breve. Dice así:

Art. $1^{\circ}$. Déjase sin efecto el carácter secreto o reservado de toda ley que haya sido sancionada con tal condición a partir de la entrada en vigor de esta ley.

Art. $2^{\circ}$. El Poder Ejecutivo deberá publicar las leyes a las que se hace mención en el artículo $1^{\circ}$ en el Boletín Oficial, en un plazo de SESENTA (60) días a partir de la sanción de la presente ley.

Art. $3^{\circ}$. Prohíbese el dictado de leyes de carácter secreto o reservado.

Art. $4^{\circ}$. Deróganse la Ley "S" 18.302 y el Decreto Ley "S" $5315 / 56$.

Art. $5^{\circ}$. Los créditos de carácter reservado y/o secreto a que se refiere la Ley de Presupuesto de la Administración Nacional vigente deben ser destinados, exclusivamente, a cuestiones de inteligencia inherentes a los organismos comprendidos en las leyes de Inteligencia Nacional, Seguridad Interior y Defensa Nacional. Queda prohibida su utilización con propósitos ajenos a dicha finalidad. El control de la rendición de los gastos relativos a cuestiones de inteligencia de los organismos mencionados en el párrafo anterior, queda a cargo de la Comisión Bicameral de Fiscalización de los Organismos y Actividades de Inteligencia.

Art. $6^{\circ}$. Comuníquese al Poder Ejecutivo.

Tras levantar el velo que pesaba sobre las leyes secretas y en cumplimiento de lo establecido por el transcripto artículo 2, el Poder Ejecutivo procedió a la publicación de las leyes que habían sido sancionadas con dicho carácter.

Así, el presidente KIRCHNER cumplió con la obligación que le habían impuesto los legisladores. Se publicaron las leyes que habían sido sancionadas en secreto. Sumaban 146 que comprendían más de un siglo -la 
primera fue dictada en 1891- y los temas más diversos -desde compras de armas hasta obsequios entre presidentes. Fueron sancionadas tanto por gobiernos democráticos como militares, aunque en proporción muy diversa. Sin perjuicio de lo que más adelante se expondrá, los primeros fueron los responsables de sólo un $20 \%$ aproximadamente, mientras que el $80 \%$ restante se gestó en los regímenes militares.

En este capítulo, expondremos el listado completo de las leyes, consignando la fecha de su sanción y efectuando una síntesis de su contenido. También distinguiremos aquellas dictadas por los gobiernos democráticos de los regímenes militares que ejercieron funciones legislativas. Nos detendremos en algunas de ellas y procuraremos determinar si en razón del contenido podía reputarse que existían motivos para imponer el carácter secreto y si es posible hallar algún criterio que orientase dicha práctica.

\section{LA PUBLICACIÓN DE LAS LEYES SECRETAS}

1. Fechas de su sanción y contenido mínimo.

En el siguiente cuadro presentamos todas las leyes que fueron sancionadas con carácter secreto y que posteriormente fueron publicadas. Para esta tarea empleamos el Boletín Oficial en su versión electrónica $^{162}$. Hemos examinado todas las leyes y utilizado la mayor capacidad de síntesis para indicar, en pocas líneas, su contenido. La ley que analizamos estableció un plazo de 60 días para la publicación de las leyes secretas. La publicación efectuada por el Poder Ejecutivo se ajustó a dicho plazo en la mayoría de los casos. Algunas fueron publicadas muy tardíamente. Las leyes 20282 y 20448 fueron publicadas el 15 de abril de 2015, esto es, casi una década después de que se ordenase su difusión. Las identificamos por su número, añadimos el año de su sanción y consignamos brevemente su contenido.

\footnotetext{
${ }^{162}$ Esta edición según la legislación vigente "reviste carácter de oficial y auténtica" y "produce idénticos efectos jurídicos que su edición impresa". Así lo establece el decreto 207/2016.
} 


\begin{tabular}{|c|c|}
\hline $\begin{array}{l}\text { NÚMERO Y AÑO } \\
\text { DE SANCIÓN }\end{array}$ & BREVE DESCRIPCIÓN DE LA MATERIA \\
\hline Ley 2802 (1891) & Inversiones buques y material de guerra. \\
\hline Ley 3060 (1894) & Aprueba crédito para adquirir material de guerra. \\
\hline Ley 3061 ( 1894) & $\begin{array}{l}\text { Autoriza al Poder Ejecutivo para vender en remate hasta cinco mil fusiles } \\
\text { MAUSER modelo alemán } 1888 \text {. }\end{array}$ \\
\hline Ley 3235 (1895) & $\begin{array}{l}\text { Autoriza al Poder Ejecutivo para invertir, en armamento, equipo y material de } \\
\text { guerra para el Ejército. }\end{array}$ \\
\hline Ley 3236 (1895) & $\begin{array}{l}\text { Autorización de gastos. Créditos para pagos provenientes del arreglo de las } \\
\text { cuestiones con Chile. }\end{array}$ \\
\hline Ley 3357 (1896) & $\begin{array}{l}\text { Autoriza al Poder Ejecutivo para invertir, hasta la suma de diez millones de } \\
\text { pesos oro sellado, en la adquisición de buques de guerra. }\end{array}$ \\
\hline Ley 3450 (1896) & Autorización para construir un arsenal y puerto militar en Bahía Blanca \\
\hline Ley 3954 (1900) & Deroga las leyes secretas 2802, 3236 y 3357. \\
\hline Ley 6283 (1908) & Autoriza la compra de buques de guerra para la Armada. \\
\hline Ley 11266 (1923) & Autoriza al Poder Ejecutivo a comprar armamento. \\
\hline Ley 11378 (1926) & Autoriza la compra de buques para la escuadra de guerra. \\
\hline Ley 12511 (1938) & $\begin{array}{l}\text { Autoriza al Poder Ejecutivo a invertir } \$ 21.850 .000 \mathrm{~m} / \mathrm{n} \text {. para cubrir las } \\
\text { diferencias de cambios y costos originadas por el cumplimiento de la ley } 11378 \\
\text { que autoriza la compra de buques para la escuadra de guerra. }\end{array}$ \\
\hline Ley 12672 (1941) & $\begin{array}{l}\text { Autoriza al Poder Ejecutivo a invertir } \$ 646.474 .545,45 \mathrm{~m} / \mathrm{n} \text { en armamento para } \\
\text { el Ejército. }\end{array}$ \\
\hline Ley 12690 (1941) & $\begin{array}{l}\text { Autoriza al Poder Ejecutivo a invertir hasta } \$ \mathrm{~m} / \mathrm{n} 712.000 .000 \text { para equipar la } \\
\text { Armada Nacional. }\end{array}$ \\
\hline Ley 12691 (1941) & $\begin{array}{l}\text { Leyes de armamentos navales. Expropiación de inmuebles para su } \\
\text { cumplimiento. }\end{array}$ \\
\hline Ley 12936 (1947) & Ratificación de gastos en armamentos para la Armada Nacional. \\
\hline Ley 12937 (1947) & Ratificación de un crédito a la Marina. \\
\hline Ley 12940 (1947) & $\begin{array}{l}\text { Aprueba los Decretos-Leyes de carácter secreto } N^{\circ} 8742 / 45 \text { y } 14.182 / 45 \text { que } \\
\text { autorizan gastos militares. }\end{array}$ \\
\hline Ley 12941 (1947) & $\begin{array}{l}\text { Amplia en } \$ 21.000 .000 \mathrm{~m} / \mathrm{n} \text {. los gastos a cubrir con el producido de títulos de } \\
\text { la deuda publica }\end{array}$ \\
\hline Ley 13220 (1948) & $\begin{array}{l}\text { Autoriza al Poder Ejecutivo a invertir } \$ 1.192 .401,56 \mathrm{~m} / \mathrm{n} \text {. para cubrir } \\
\text { diferencias de cambio originadas por el cumplimiento de la ley } 11.378\end{array}$ \\
\hline Ley 13564 (1949) & Ejército créditos para su equipamiento y modernización \\
\hline Ley 14041 (1951) & Acopio de materiales para la Marina de Guerra. \\
\hline Ley 14047 (1951) & El Estado asume el monopolio de la exportación de armas de guerra \\
\hline Ley 14096 (1951) & Aumento de gastos para construcciones militares. \\
\hline Ley 16438 (1961) & $\begin{array}{l}\text { Armada Nacional: plan de renovaciones y adquisiciones de unidades navales, } \\
\text { aeronavales y elementos de infantería de marina }\end{array}$ \\
\hline Ley 16916 (1966) & $\begin{array}{l}\text { Declárase en situación de retiro efectivo obligatorio al General de División } \\
\text { Carlos Augusto Caro }\end{array}$ \\
\hline Ley 17112 (1967) & $\begin{array}{l}\text { Aprueba el Estatuto para el Personal Civil de la Secretaria de Informaciones de } \\
\text { Estado y de los servicios de inteligencia de las Fuerzas Armadas }\end{array}$ \\
\hline
\end{tabular}




\begin{tabular}{|c|c|}
\hline Ley 17266 (1967) & $\begin{array}{l}\text { Amplía en } 45 \text { días el plazo a que hace referencia el artículo } 18^{\circ} \text { de la ley "S" } \\
\text { nro. } 17.112 \text { (Estatuto para el Personal Civil de la SIDE y de los servicios de } \\
\text { inteligencia de las Fuerzas Armadas) }\end{array}$ \\
\hline Ley 17459 (1967) & $\begin{array}{l}\text { Fuerzas Armadas: transferencias de equipamiento a título definitivo y sin cargo } \\
\text { a la República de Bolivia }\end{array}$ \\
\hline Ley 17488 (1967) & $\begin{array}{l}\text { Modificación de la Ley Orgánica para el Cuerpo de Informaciones de } \\
\text { Coordinación Federal }\end{array}$ \\
\hline Ley 17599 (1967) & $\begin{array}{l}\text { Modificación del Presupuesto General de la Administración Nacional para el } \\
\text { año } 1967 .\end{array}$ \\
\hline Ley 17845 (1968) & $\begin{array}{l}\text { Desafectar del uso naval el inmueble ubicado en la Avenida Presidente Julio A. } \\
\text { Roca y calle Chacabuco de la Capital Federal, disponiendo su posterior venta. }\end{array}$ \\
\hline Ley $17846(1968)$ & $\begin{array}{l}\text { Expropiación. Tierras Base Naval Puerto Belgrano (Partido de Coronel de } \\
\text { Marina Leonardo Rosales, provincia de Buenos Aires) }\end{array}$ \\
\hline Ley 18117 (1969) & $\begin{array}{l}\text { El Poder Ejecutivo Nacional procederá a unificar y consolidar los valores } \\
\text { públicos no negociables denominados "Obligaciones de Previsión Social" y } \\
\text { "Plan de Inversión y Capitalización" en existencia al } 31 \text { de diciembre de } 1968 \text {, } \\
\text { en las cajas nacionales de Previsión Social enumeradas en la ley 17.575, } \\
\text { mediante su reemplazo por bonos del Tesoro a perpetuidad que no } \\
\text { devengaran intereses. }\end{array}$ \\
\hline Ley 18211 (1969) & $\begin{array}{l}\text { El Poder Ejecutivo procederá a donar al Ejercito de la República de Bolivia un } \\
\text { caballo de armas. }\end{array}$ \\
\hline Ley 18230 (1969) & $\begin{array}{l}\text { Autoriza al Poder Ejecutivo Nacional a donar a la Fuerza Aérea de la República } \\
\text { del Paraguay tres aviones Douglas DC-3. }\end{array}$ \\
\hline Ley 18231 (1969) & $\begin{array}{l}\text { Autoriza al Poder Ejecutivo Nacional a donar a la Fuerza Aérea de la República } \\
\text { de Bolivia tres aviones Douglas DC-3. }\end{array}$ \\
\hline Ley 18236 (1969) & $\begin{array}{l}\text { Aprueba el "Acuerdo argentino-boliviano para el establecimiento de una misión } \\
\text { naval Argentina en la República de Bolivia" }\end{array}$ \\
\hline Ley 18296 (1969) & $\begin{array}{l}\text { Donar al Ejército de la República de Bolivia seis caballos de silla, tipo oficial, } \\
\text { cuyo valor asciende a la suma de trescientos sesenta mil pesos moneda } \\
\text { nacional }(m \$ n 360.000,00) \text {. }\end{array}$ \\
\hline Ley 18302 (1969) & $\begin{array}{l}\text { Organismos autorizados a recibir créditos para atender gastos de carácter } \\
\text { reservado y/o secreto. }\end{array}$ \\
\hline Ley 18378 (1969) & $\begin{array}{l}\text { Transferencia definitiva y sin cargo de materiales a la fuerza naval de la } \\
\text { República de Bolivia. }\end{array}$ \\
\hline Ley 18395 (1969) & $\begin{array}{l}\text { Anticipo a la Secretaría de Difusión y Turismo para regularizar el estado } \\
\text { económico financiero de las emisoras comerciales de radio y televisión. }\end{array}$ \\
\hline Ley 18431 (1969) & $\begin{array}{l}\text { Jubilaciones. Personal comprendido en la ley } 17112 \text { (Personal Civil de la } \\
\text { Secretaria de Informaciones de Estado y de los servicios de inteligencia de las } \\
\text { Fuerzas Armadas). }\end{array}$ \\
\hline Ley 18503 (1969) & $\begin{array}{l}\text { Estatuto para el personal civil de inteligencia de la Secretaria de Informaciones } \\
\text { de Estado y de las Fuerzas Armadas. }\end{array}$ \\
\hline Ley 18510 (1969) & $\begin{array}{l}\text { Modificación del Presupuesto General de la Administración Nacional. } \\
\text { Comando en Jefe del Ejército y Cuentas Especiales. }\end{array}$ \\
\hline Ley 18532 (1969) & $\begin{array}{l}\text { Modificación del Presupuesto General de la Administración Nacional } \\
\text { (Secretaria de Estado de Hacienda. Cuentas Especiales) }\end{array}$ \\
\hline Ley 18536 (1969) & $\begin{array}{l}\text { Corporación del Mercado Central de Buenos Aires aporte de capital. } \\
\text { Ampliación }\end{array}$ \\
\hline Ley 18579 (1970) & $\begin{array}{l}\text { Dirección General de Fabricaciones Militares anticipo para cancelar deudas } \\
\text { previsionales del organismo. }\end{array}$ \\
\hline Ley 18623 (1970) & Secretaria de Información del Estado. Establece remuneraciones. \\
\hline Ley 18632 (1970) & Ferrocarriles Argentinos. Desafecta un inmueble. \\
\hline Ley 18640 (1970) & Jubilaciones. Policía Federal \\
\hline Ley 18649 (1970) & Sociedad Mixta Siderurgia Argentina. Productos Importados \\
\hline Ley 18720 (1970) & Donación de terreno para la Asociación de Tiro Corrientes. \\
\hline
\end{tabular}




\begin{tabular}{|c|c|}
\hline Ley 18757 (1970) & $\begin{array}{l}\text { Donación a la República del Paraguay } 20 \text { yeguas mestizas y } 1 \text { padrillo anglo } \\
\text { argentino. }\end{array}$ \\
\hline Ley 18802 (1970) & Policía Federal. Importación de material bélico \\
\hline Ley 18869 (1970) & $\begin{array}{l}\text { Jubilaciones. Personal Ministerio del Interior y ex Secretaría de Estado de } \\
\text { Gobierno. }\end{array}$ \\
\hline Ley 18895 (1970) & Policía Federal Argentina. Escalafón secreto. Creación. \\
\hline Ley 18926 (1971) & Policía Federal. Remuneraciones. \\
\hline Ley 18964 (1971) & Donación al Colegio Militar de la República de Bolivia 20 caballos mestizos. \\
\hline Ley 19050 (1971) & $\begin{array}{l}\text { Ascenso post-mortem al grado inmediato superior al Teniente Mario César } \\
\text { Asua. }\end{array}$ \\
\hline Ley $19083(1971)$ & Secretaría de Informaciones de Estado personal. Incorporación. \\
\hline Ley $19111(1971)$ & Cámara Federal en lo Penal de la Nación. Remuneraciones. \\
\hline Ley 19137 (1971) & Plan de reequipamiento de la Policía Federal Argentina. \\
\hline Ley 19173 (1971) & $\begin{array}{l}\text { Jubilaciones y pensiones de trabajadores en relación de dependencia. } \\
\text { Modificación. }\end{array}$ \\
\hline Ley 19193 (1971) & Donación al Ejército de la República de Bolivia \\
\hline Ley 19245 (1971) & Donación al Ejército de la República del Paraguay. \\
\hline Ley $19248(1971)$ & Políticas nacionales secretas. \\
\hline Ley 19260 (1971) & Comando en Jefe del Ejército. Modificación de la ley 14.366. \\
\hline Ley 19295 (1971) & $\begin{array}{l}\text { Donación al presidente de la República del Perú General de División D. Juan } \\
\text { Velasco Alvarado un caballo de armas. }\end{array}$ \\
\hline Ley 19296 (1971) & Donación de equipos para la Guardia Nacional de la República de Bolivia. \\
\hline Ley 19302 (1971) & $\begin{array}{l}\text { Excluyen del pago de todo tipo de impuesto y/o gravamen a la adquisición e } \\
\text { importación del juego de cristalería y vajilla de porcelana efectuada por la } \\
\text { presidencia de la Nación. }\end{array}$ \\
\hline Ley 19348 (1971) & $\begin{array}{l}\text { Exceptúa de la suspensión de importación y exime del derecho adicional a las } \\
\text { importaciones de material bélico secreto que efectúen el Comando en Jefe del } \\
\text { Ejército, el Comando en Jefe de la Armada y el Comando en Jefe de la Fuerza } \\
\text { Aérea. }\end{array}$ \\
\hline Ley 19364 (1971) & $\begin{array}{l}\text { Anticipo financiero a la Administración General de Emisoras Comerciales de } \\
\text { Radio y Televisión. }\end{array}$ \\
\hline Ley 19373 (1971) & $\begin{array}{l}\text { Estatuto para el Personal Civil de Inteligencia de la Secretaría de } \\
\text { Informaciones de Estado y de las Fuerzas Armadas. }\end{array}$ \\
\hline Ley 19391 (1971) & $\begin{array}{l}\text { Prorroga el incremento extraordinario de la remuneración mensual que percibe } \\
\text { el personal de la Policía Federal por "riesgo profesional". }\end{array}$ \\
\hline Ley 19194 (1972) & $\begin{array}{l}\text { Modifica la ley 19194. Renegociación de convenios firmados por ingenios } \\
\text { azucareros }\end{array}$ \\
\hline Ley 19459 (1972) & $\begin{array}{l}\text { Convenio comercial suscripto entre la República Argentina y la Unión de } \\
\text { Repúblicas Socialistas Soviéticas }\end{array}$ \\
\hline Ley $19474(1972)$ & $\begin{array}{l}\text { Donación a la República de Francia de un uniforme histórico del Regimiento } 10 \\
\text { de Tiradores de Caballería Blindada "Húsares de Pueyrredón". }\end{array}$ \\
\hline
\end{tabular}




\begin{tabular}{|c|c|}
\hline Ley 19481 (1972) & $\begin{array}{l}\text { Donación a la República de Chile de un uniforme histórico del Regimiento } 11 \\
\text { de Infantería de Montaña "General Las Heras". }\end{array}$ \\
\hline Ley 19566 (1972) & $\begin{array}{l}\text { Promueve al grado inmediato superior postmortem, con fecha } 10 \text { de abril de } \\
\text { 1972, al General de División don Juan Carlos Sánchez }\end{array}$ \\
\hline Ley 19602 (1972) & $\begin{array}{l}\text { Promuévase al grado inmediato superior, por mérito extraordinario, con fecha } \\
10 \text { de abril de 1972, al Suboficial Principal Conductor Motorista Celestino } \\
\text { Barneche. }\end{array}$ \\
\hline Ley $19621(1972)$ & $\begin{array}{l}\text { Autoriza la realización de ajustes presupuestarios correspondientes al ejercicio } \\
\text { fiscal } 1971 \text { y sus actos consecuentes. }\end{array}$ \\
\hline Ley 19663 (1972) & Incremento de remuneraciones del Servicio Penitenciario General. \\
\hline Ley 19803 (1972) & $\begin{array}{l}\text { Modifica el régimen de jubilaciones y pensiones para los trabajadores en } \\
\text { relación de dependencia aprobado por la ley } 18037\end{array}$ \\
\hline Ley 19815 (1972) & $\begin{array}{l}\text { Autorización a Gas del Estado en razón de la emergencia. Adquisiciones y } \\
\text { contrataciones de bienes y servicios. }\end{array}$ \\
\hline Ley $19816(1972)$ & $\begin{array}{l}\text { Transferencia gratuita de un inmueble en Capital Federal al Sindicato de } \\
\text { Obreros y Empleados de la Educación y la Minoridad (S.O.E.M.E.). }\end{array}$ \\
\hline Ley 19817 (1972) & $\begin{array}{l}\text { Donación al Presidente de la República del Paraguay, General de Ejército D. } \\
\text { Alfredo STROESSNER, un padrillo pura sangre de carrera. }\end{array}$ \\
\hline Ley 19867 (1972) & $\begin{array}{l}\text { Autoriza a la Junta de Comandantes en Jefe (Estado Mayor Conjunto) a } \\
\text { disponer de créditos destinados a atender gastos de carácter reservado y/o } \\
\text { secreto. }\end{array}$ \\
\hline Ley 19896 (1972) & $\begin{array}{l}\text { Ascenso al grado inmediato superior a los tenientes médicos residentes en } \\
\text { comisión Pablo Ramón Cánepa, Mario Horacio Aleson y Norberto Jorge } \\
\text { Casais. }\end{array}$ \\
\hline Ley 19910 (1972) & $\begin{array}{l}\text { Crédito suscripto el } 6 \text { de octubre de 1972, entre el Banco Central de la } \\
\text { República Argentina y bancos privados de los Estados Unidos de América por } \\
145.000 .000 \text { de dólares. }\end{array}$ \\
\hline Ley 19930 (1972) & $\begin{array}{l}\text { Se modifica la ley } 19194 \text { y se autoriza al Ministerio de Comercio y a otros } \\
\text { organismos a convenir nuevas modalidades, medios y formas de pago, para la } \\
\text { recuperación de los créditos que el Estado tenga contra las empresas } \\
\text { azucareras. }\end{array}$ \\
\hline Ley 19942 (1972) & $\begin{array}{l}\text { Otorga carácter de donación al subsidio acordado a la "Cooperativa de la } \\
\text { Vivienda del Personal del Ministerio de Hacienda Ltda." }\end{array}$ \\
\hline Ley 19966 (1972) & $\begin{array}{l}\text { Arreglos de créditos celebrados con la banca privada de los Estados Unidos, } \\
\text { para la adquisición de elementos para el reequipamiento de las Fuerzas } \\
\text { Armadas. }\end{array}$ \\
\hline Ley $19981(1972)$ & $\begin{array}{l}\text { Convenios de crédito suscriptos por el Banco Central de la República Argentina } \\
\text { con bancos de diversos países de Europa Occidental, Canadá y Japón. }\end{array}$ \\
\hline Ley $19991(1972)$ & $\begin{array}{l}\text { Préstamo entre Hierro Patagónico de Sierra Grande Sociedad Anónima Minera } \\
\text { y Export Development Corporation. }\end{array}$ \\
\hline Ley 19992 (1972) & $\begin{array}{l}\text { Dispone la emisión de un bono seriado de la República Argentina con tasa de } \\
\text { interés variable. }\end{array}$ \\
\hline Ley 20045 (1972) & $\begin{array}{l}\text { Promueve al grado inmediato superior post mortem al señor Contraalmirante } \\
\text { Emilio Rodolfo Berisso. }\end{array}$ \\
\hline Ley 20054 (1972) & Policía Federal. Incremento de remuneraciones. \\
\hline Ley $20083(1973)$ & Ministerio de Hacienda y Finanzas. Ajustes presupuestarios. \\
\hline Ley 20110 (1973) & Creación del Servicio Nacional de la Familia. \\
\hline Ley 20168 (1973) & $\begin{array}{l}\text { Incremento y extensión a todo el personal de Seguridad y Defensa de la Policía } \\
\text { Federal del suplemento por riesgo profesional. }\end{array}$ \\
\hline Ley 20195 (1973) & $\begin{array}{l}\text { Establece la misión, organización y funciones de la Secretaria de Información } \\
\text { de Estado. }\end{array}$ \\
\hline Ley 20232 (1973) & $\begin{array}{l}\text { Donación a la República del Paraguay, con destino a su Ejército, de dos } \\
\text { padrillos pura sangre de carrera. }\end{array}$ \\
\hline Ley 20251 (1973) & $\begin{array}{l}\text { Promueve al grado inmediato superior post mortem, con fecha } 4 \text { de abril de } \\
\text { 1973, al señor Coronel Héctor Alberto Iribarren. }\end{array}$ \\
\hline
\end{tabular}




\begin{tabular}{|c|c|}
\hline Ley 20252 (1973) & $\begin{array}{l}\text { Modifica el carácter con cargo de reintegro de varios anticipos del Tesoro } \\
\text { otorgados a Cuentas Especiales del Comando en Jefe de la Armada. }\end{array}$ \\
\hline Ley 20282 (1973) & $\begin{array}{l}\text { Exime del pago de impuestos a la venta de } 752 \text { vacunos subastados en remate } \\
\text { público por la Sociedad Rural de San Justo, provincia de Santa Fe, cuyo } \\
\text { producido se destinará a la ayuda y reconstrucción del área afectada por el } \\
\text { siniestro que azotó a dicha ciudad. }\end{array}$ \\
\hline Ley 20339 (1973) & $\begin{array}{l}\text { Promueve al grado inmediato superior post mortem, con fecha } 30 \text { de abril de } \\
1973 \text {, al señor Contraalmirante (R.E.) Hermes José Quijada. }\end{array}$ \\
\hline Ley 20394 (1973) & Promueve al grado inmediato superior al Cabo Primero Rufino Ocampo. \\
\hline Ley 20417 (1973) & $\begin{array}{l}\text { Aprueba el Estatuto Personal Civil del Servicio de Inteligencia Penitenciario } \\
\text { Federal. }\end{array}$ \\
\hline Ley 20448 (1973) & $\begin{array}{l}\text { Ratifica el arreglo de crédito celebrado con representantes del gobierno de los } \\
\text { Estados Unidos de América, para la adquisición de elementos de defensa con } \\
\text { destino al reequipamiento de las Fuerzas Armadas. }\end{array}$ \\
\hline Ley 21359 (1976) & Modifica el Presupuesto General de la Administración Nacional 1976. \\
\hline Ley 21442 (1976) & $\begin{array}{l}\text { Deroga la participación de la Confederación General Económica y de la } \\
\text { Confederación General del Trabajo en entidades de la Administración Pública y } \\
\text { en empresas del Estado. }\end{array}$ \\
\hline Ley $21473 / 1976$ & Personal militar - Condecoraciones otorgadas por gobiernos extranjeros \\
\hline Ley 21475 (1976) & Modifica la ley orgánica de la Policía Federal. \\
\hline Ley 21504 (1977) & Efectúa una promoción en el escalafón del clero castrense. \\
\hline Ley 21512 (1977) & Modifica la Ley Orgánica de la Policía Federal. \\
\hline Ley 21627 (1977) & Modifica la ley secreta 18302. \\
\hline Ley 21681 (1977) & Modifica la ley secreta 18302. Incorpora la Policía Aeronáutica Nacional. \\
\hline Ley 21705 (1977) & $\begin{array}{l}\text { Modifica la ley secreta } 19373 \text { (Carrera de Personal y Remuneraciones del } \\
\text { personal de inteligencia). }\end{array}$ \\
\hline Ley 21770 (1978) & $\begin{array}{l}\text { Autorización para importar equipamiento a la Policía de la Provincia de Buenos } \\
\text { Aires. }\end{array}$ \\
\hline Ley 21774 (1978) & $\begin{array}{l}\text { Autoriza la venta del inmueble situado en Praia de Botafogo Nro. 228, Río de } \\
\text { Janeiro, República Federativa de Brasil. }\end{array}$ \\
\hline Ley 21798 (1978) & Personal militar. Condecoraciones otorgadas por gobiernos extranjeros. \\
\hline Ley 21817 (1978) & Autoriza un plan de reequipamiento a las Policías provinciales. \\
\hline Ley 21863 (1978) & Donación a la Policía de la ciudad de Asunción, República del Paraguay. \\
\hline Ley 21868 (1978) & $\begin{array}{l}\text { Modificación de la ley } 21792 \text { (sueldos y categorías Poder Judicial de la } \\
\text { Nación). }\end{array}$ \\
\hline Ley 21880 (1978) & Personal militar. Honores conferidos por gobiernos extranjeros. \\
\hline Ley 21887 (1978) & $\begin{array}{l}\text { Yacimientos Petrolíferos Fiscales Sociedad del Estado. Excepción para adquirir } \\
\text { equipos. }\end{array}$ \\
\hline Ley 21920 (1979) & Modifica la ley 21868 (sueldos y categorías Poder Judicial de la Nación). \\
\hline Ley 21989 (1979) & $\begin{array}{l}\text { Transfiere material, en comodato, a las policías de la ciudad de La Paz } \\
\text { (Bolivia) y de Quito (Ecuador). }\end{array}$ \\
\hline Ley 21996 (1979) & Modifica la ley 21920 (sueldos y categorías Poder Judicial de la Nación). \\
\hline Ley 22033 (1979) & $\begin{array}{l}\text { Incorpora a la Comisión Nacional de Energía Atómica para recibir gastos } \\
\text { reservados conforme la ley } 18302 \text {. }\end{array}$ \\
\hline
\end{tabular}




\begin{tabular}{|c|c|}
\hline Ley 22085 (1979) & $\begin{array}{l}\text { Incorpora al Ministerio del Interior para recibir gastos reservados conforme la } \\
\text { ley } 18302 \text {. }\end{array}$ \\
\hline Ley 22118 (1979) & Personal Congreso de la Nación. Escalafones, categorías y remuneraciones. \\
\hline Ley 22122 (1979) & $\begin{array}{l}\text { Autoriza la constitución de una sociedad del Estado en jurisdicción del } \\
\text { Ministerio de Defensa -Comando en Jefe del Ejército- para el desarrollo del } \\
\text { Proyecto TAM (Tanque Argentino Mediano). }\end{array}$ \\
\hline Ley 22174 (1980) & Remuneraciones de los Ministros, Secretarios de Estado y Subsecretarios. \\
\hline Ley $22215(1980)$ & $\begin{array}{l}\text { Régimen de exención (ley } 21.770 \text { ) a las policías provinciales y del Territorio } \\
\text { Nacional de la Tierra del Fuego, Antártida e Islas del Atlántico Sud para } \\
\text { importar equipos. }\end{array}$ \\
\hline Ley $22281(1980)$ & $\begin{array}{l}\text { Incrementa en } \$ 712.200 .000 .000 \text { el total de erogaciones del Presupuesto } \\
\text { General de la Administración Nacional vigente (año 1980. Administración } \\
\text { Central y Cuentas Especiales). }\end{array}$ \\
\hline Ley 22474 (1981) & Pensiones. Otorgamiento. \\
\hline Ley 22489 (1981) & $\begin{array}{l}\text { Incrementa en } \$ 2.088 .040 .000 .000 \text { el total de las erogaciones del Presupuesto } \\
\text { General de la Administración Nacional (Administración Central, Cuentas } \\
\text { Especiales y Organismos Descentralizados) año } 1981 \text {. }\end{array}$ \\
\hline Ley 22559 (1982) & Seguridad Nacional. Teatro de operaciones y gobernaciones militares. \\
\hline Ley 22576 / 1982 & Pensiones. Otorgamiento. \\
\hline Ley 22592 (1982) & Pensiones. Otorgamiento. \\
\hline Ley 22637 (1982) & Pensiones. Otorgamiento. \\
\hline Ley 22642 (1982) & $\begin{array}{l}\text { Convalida operaciones crediticias realizadas por los Comandos en Jefe del } \\
\text { Ejército, de la Armada y de la Fuerza Aérea. }\end{array}$ \\
\hline Ley 22862 (1983) & $\begin{array}{l}\text { Condona los intereses resarcitorios que deben tributarse respecto de aquellos } \\
\text { combustibles y/o lubricantes, que hubieran sido puestos a disposición de las } \\
\text { Fuerzas Armadas en operaciones. }\end{array}$ \\
\hline Ley $22952(1983)$ & Pensiones. Otorgamiento. \\
\hline
\end{tabular}

\section{Frecuencia en su sanción.}

Desde la primera -sancionada el 17 de septiembre de 1891 - hasta la última - 19 de octubre de 1983- este instrumento se usó con dispar intensidad. El cuadro que sigue muestra la frecuencia con qué los distintos gobiernos lo emplearon. La década con que se inició la práctica alcanzó el número de 7 leyes que declinó hasta registrarse una -la iniciada en 1910- en la que no se sancionó ninguna ley. El fenómeno adquirió un nuevo impulso en la década del sesenta y en la siguiente, registra el mayor índice - con 87 leyessobre un total de 146 en toda la historia institucional del país.

El siguiente gráfico refleja el número de leyes que fueron sancionadas ordenadas por décadas: 


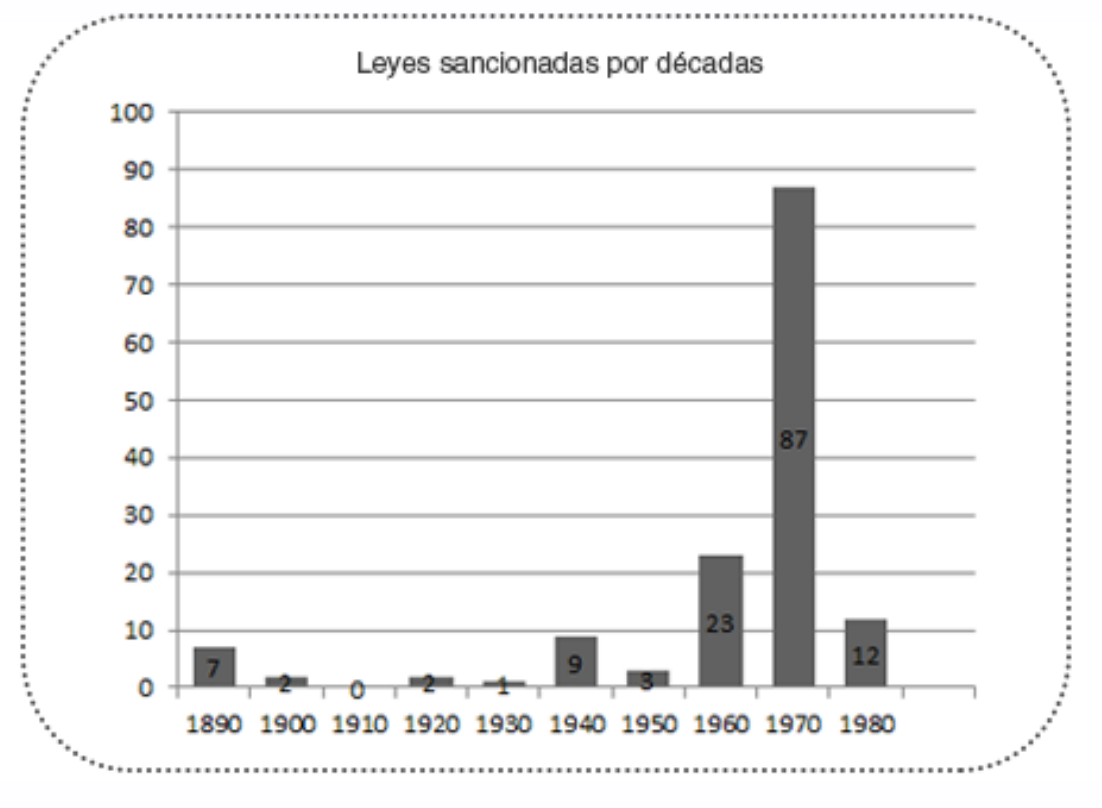

3. Gobiernos de facto y democráticos.

Las denominadas leyes secretas fueron sancionadas tanto bajo la vigencia de gobiernos democráticos como regímenes de facto que irrumpieron periódicamente en la vida institucional de la Argentina. Esta comprobación exige formular una aclaración muy relevante. Durante los primeros, fue el Congreso el que sancionó la ley, conforme las disposiciones de la Constitución nacional pero, claramente, ello no sucedió en los gobiernos militares que se sucedieron a partir de 1930. En estos casos, el Poder Ejecutivo asumía funciones legislativas frente a la clausura del Congreso de la Nación. Es claro entonces que estos últimos no podían sancionar leyes en sentido constitucional y que sus leyes no eran propiamente tales. La llamada Revolución Libertadora denominó a su actividad legislativa decretos-leyes pero la siguiente Revolución Argentina abandonó esa práctica, le dio denominación de leyes y le asignó una numeración correlativa. De este modo, en el ordenamiento jurídico argentino distinguir unas de otras exige conocer la fecha de su sanción. Esta razón motivó que en el primero de los cuadros, luego del número de la ley indicáramos el año de su sanción para facilitar esta distinción. Algunos juristas denunciaron la situación: "Iniciada en 1966 la Revolución 
Argentina señalamos de inmediato el error semántico y político de llamar leyes a los decretos-leyes del gobierno de facto, uso lingüístico que tenía una expresa voluntad legitimadora del gobierno. Han sido pocos los juristas que eligieron en su momento llamarlos como corresponde ('decreto-ley' o 'así llamada ley') y por ello el uso cotidiano de este país emergente recibe pleno el deterioro de los principios. Hasta el día de hoy encontramos libros, fallos, doctrinas, que a décadas de terminado el último gobierno de facto, todavía prosiguen con ese peligroso uso legitimador"163.

Los gobiernos militares encabezados por el general José Félix URIBURU (1930) y Eduardo E. LONARDI (1955) y sus continuadores no emplearon leyes secretas ${ }^{164}$. Los posteriores inaugurados por Juan C. ONGANÍA (1966) y Jorge R. VIDELA (1976) fueron los mayores productores de leyes secretas: 118 sobre 146 que corresponden a toda la historia institucional del país.

El siguiente gráfico muestra el número de leyes sancionadas bajo gobiernos democráticos y militares:

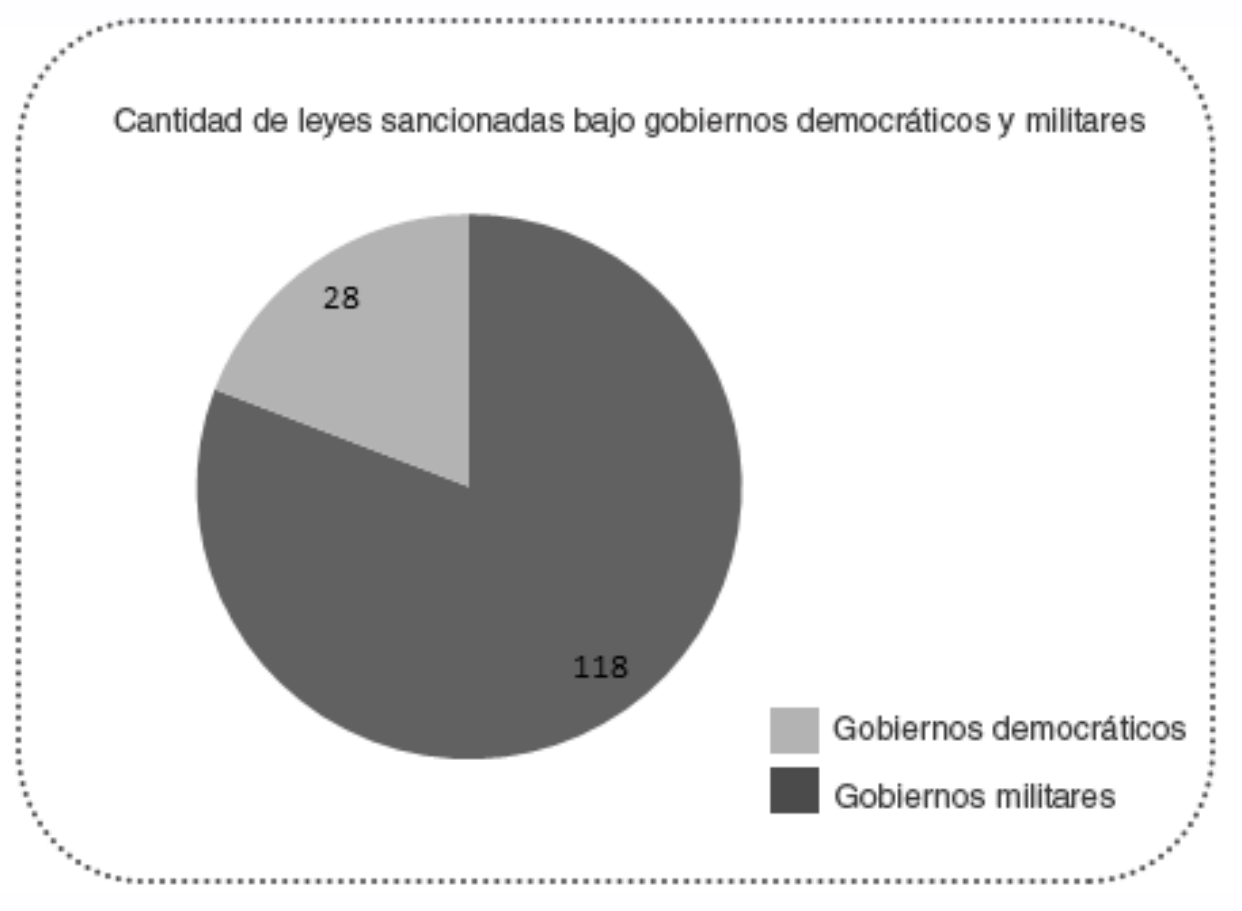

${ }^{163}$ GoRdillo, Agustín A., Tratado de derecho administrativo, Buenos Aires, Fundación de Derecho Administrativo, 2013, tomo I, p. VII-6. Énfasis en el original.

${ }^{164} \mathrm{~A}$ comienzos de la década del cincuenta se sancionaron tres leyes, pero corresponden al gobierno del presidente PERÓN. 
4. Una visión general.

La lectura de las leyes sancionadas permite distinguir la existencia de tres etapas en el uso del secreto legislativo.

a) La primera comprende desde la primera -sancionada en $1891^{165}$ durante la presidencia de Carlos E. J. PELLEGRINI (1890-1892)- hasta $1900^{166}$. Se caracteriza por haber empleado el secreto sólo para asuntos de naturaleza militar. Este empleo armoniza con el generalizado reconocimiento de que las cuestiones referidas a seguridad, defensa o política exterior pueden permanecer reservadas.

Pero el aspecto más relevante es que el período concluye con la sanción de una ley que levanta el secreto que se le había impuesto a las anteriores. Es decir el período inaugural del secreto legislativo en la Argentina concluye tras nueve años, plazo que el Congreso consideró que podía prolongarse la falta de publicidad. Se trata de un antecedente muy valioso pues al examinar -en el capítulo anterior- al que denominamos secreto democrático, señalamos que la temporalidad del secreto era uno de los requisitos que lo legitimaban como instrumento en los regímenes no autocráticos.

El Congreso daba inicio con la sanción de la ley 3954 a una práctica -la revisión periódica del secreto- que sólo fue reiterada más de un siglo después. Como se aprecia, la conveniencia de concluir el secreto legislativo fue advertida tempranamente -aquella ley fue sancionada el $1^{\circ}$ de octubre de $1900-{ }^{167}$ pero el ejemplo no se reiteró hasta el año 2006.

b) La segunda comprende hasta 1951. Durante esta etapa se produjo el golpe militar encabezado por José F. URIBURU (1930-1932) que no hizo uso de las leyes secretas. No lo había hecho tampoco el depuesto presidente Hipólito YRIGOYEN (1928-1930) pero sí su antecesor del mismo partido, Marcelo T. de ALVEAR (1922-1928) que asistió a la sanción de ellas, en dos oportunidades.

Durante los cincuenta años que comprende esta etapa sólo se sancionaron 16 leyes que representan el 10,95\%, cifra que traduce un empleo moderado del secreto. Como en la anterior, se reiteran los motivos del

\footnotetext{
165 La ley 2802.

166 La ley 3954.

${ }^{167}$ La publicación en el Boletín Oficial corresponde el 4 de ese mismo mes y año.
} 
secreto: armamentos, gastos militares, expropiación de inmuebles con dichos fines.

c) La última etapa comprende hasta 1983. Contrasta con la anterior por la variedad de temas a los que se les impuso el secreto ampliando el catálogo de materias hasta entonces había sido reconocido- y por la cantidad de leyes que se registraron. En este último sentido, bastará con señalar que se sancionaron 122 leyes que representan el 83,56 \%. La primera de este período fue durante la presidencia de Arturo FRONDIZI (1958-1962) y fue la única y última sancionada durante un gobierno democrático ${ }^{168}$.

Aunque el dato más notorio está constituido por la cantidad de leyes dictadas, el incremento no sólo fue cuantitativo sino cualitativo por la incorporación de nuevos asuntos que las autoridades consideraron que debían permanecer secretos. En otros términos, las cuestiones referidas a seguridad, defensa o política exterior siguieron siendo asuntos reservados pero se incluyeron muchas otras. Se efectuaron ascensos militares de contenido reivindicatorio mediante leyes secretas. El supuesto más notable es el de los ascensos post mortem de militares muertos en enfrentamientos armados. Así, por ejemplo, los casos del Contraalmirante Emilio R. BERISSO ${ }^{169}$, asesinado en un atentado del 28 de diciembre de 1972 atribuido a las Fuerzas Armadas Revolucionarias (FAR) y del Contraalmirante Hermes QUIJADA ${ }^{170}$, muerto el 30 de abril de 1973 por integrantes del Ejército Revolucionario del Pueblo (ERP). QUIJADA había tenido a su cargo el discurso que dio la versión oficial sobre las muertes ocurridas en el hecho conocido como matanza de Trelew, el 22 de agosto de 1972. Allí, aparentando una evasión de los prisioneros de distintas agrupaciones políticas detenidos en el penal de la ciudad de Rawson, provincia del Chubut, una patrulla militar ejecutó a 19 de ellos ${ }^{171}$.

También se otorgaron pensiones; se condonaron deudas; se expropiaron inmuebles; se otorgaron remuneraciones especiales a los

\footnotetext{
${ }^{168}$ Se trata de la ley 16438 que autorizó al Poder Ejecutivo a invertir una suma de dinero en construcciones destinadas a la Armada Nacional.

${ }_{169}$ Mediante la ley 20045 (1972).

170 Mediante la ley 20339 (1973).

${ }^{171}$ Véase PitTAluga Roberto, "La memoria según Trelew" en "Sociohistórica. Cuadernos del CISH", No 19/20, La Plata, Universidad Nacional de La Plata, p. 81. Cuarenta años después de esos hechos, el Poder Judicial condenó a algunos de los responsables en un juicio en el que intervino la justicia federal con sede en Comodoro Rivadavia. Los crímenes fueron considerados de lesa humanidad.
} 
jueces $^{172}$ y a las fuerzas de seguridad; se efectuaron regalos a mandatarios extranjeros -desde caballos ${ }^{173}$ a trajes militares-; se donaron terrenos a instituciones de práctica de tiro; se autorizó el pago de gastos reservados a los agentes públicos; se permitió el ingreso de vajilla para la residencia presidencial de Olivos sin pagar tributos aduaneros, etc.

5. Análisis particular de algunas leyes.

El examen individual de todas las leyes que fueron sancionadas como secretas supera el propósito de este trabajo pero es significativo tener en cuenta, al menos, qué es lo que se consideró que debía permanecer reservado en distintos momentos de la historia legislativa. Con ese fin hemos escogido algunas leyes para examinarlas con mayor detenimiento.

a) La inauguración legislativa del secreto.

Se trata de la ley 2802, como se mencionó, sancionada el 17 de septiembre de 1891 bajo la presidencia de PeLLEGRINI. Su breve extensión e importancia histórica justifican su transcripción:

Art. $1^{\circ}$. Apruébase los gastos hechos por el Poder Ejecutivo en virtud del acuerdo de Gobierno de $1^{\circ}$ de marzo de 1889 para adquirir buques y material de guerra.

Art. $2^{\circ}$. Autorízasele igualmente a invertir hasta cuatro millones de pesos oro en completar esas y demás adquisiciones necesarias al mismo efecto.

Art. $3^{\circ}$. Se destina especialmente para cubrir los gastos que origine la autorización contenida en el artículo anterior, el producto de la venta del Ferrocarril Andino de Villa María a Villa Mercedes.

Art. $4^{\circ}$. El Poder Ejecutivo queda autorizado también a vender mil leguas de tierras públicas en los territorios Nacionales, al precio mínimo de cinco mil pesos moneda nacional de curso legal, por legua cuadrada, cuyo producto se

\footnotetext{
${ }^{172}$ Las remuneraciones de éstos, sea que integraran la Corte Suprema de Justicia de la Nación, las Cámaras de Apelación o los juzgados de primera instancia se establecían por una ley secreta. Se consagraba una remuneración total que estaba integrada por un sueldo básico y una compensación jerárquica. Ésta, generalmente, duplicaba a aquél. Las leyes 21792 (1978), 21868 (1978) y 21996 (1979) así lo dispusieron.

${ }^{173}$ La ley 20232 sancionada bajo la presidencia de Alejandro Agustín LANUSSE (1971-1973) dice que "el Poder Ejecutivo procederá a donar al Gobierno de la República del Paraguay, con destino a su Ejército, dos (2) padrillos sangre pura de carrera" y se justifica en que "la donación tiene un valor simbólico importante como muestra de un sentimiento favorable de nuestras Fuerzas Armadas". Para la fecha aquélla era gobernada por el General Alfredo STROESSNER que se mantuvo en el poder 1954 hasta 1989. LANUSSE efectuó una visita oficial a Asunción en diciembre de 1971.
} 
aplicará igualmente a cubrir los gastos de que tratan los artículos $1^{\circ}$ y $2^{\circ}$ de esta Ley.

Art. $5^{\circ}$. Mientas no se realice la venta del Ferrocarril Andino, o la venta de las tierras indicadas en el Art. $4^{\circ}$ el Poder Ejecutivo queda facultado para levantar los fondos necesarios por medio de operaciones de crédito pudiendo al efecto afectar el Ferrocarril mencionado o las mil leguas de tierras; y en caso necesario alguna de las rentas especiales de que la Nación pueda disponer libremente.

Art. $6^{\circ}$. El Poder Ejecutivo nombrará una Comisión Especial compuesta de cinco ciudadanos; dos de los cuales por el Departamento de Hacienda y tres por el de Guerra y Marina, a fin de que haga las veces de las oficinas encargadas de controlar los gastos que se hagan en virtud de esta Ley.

Art. $7^{\circ}$. En las primeras Sesiones de cada año el Poder Ejecutivo dará cuenta al $\mathrm{H}$. Congreso, en pliego reservado, de las adquisiciones que hubiera hecho.

Art. $8^{\circ}$. En Sesión pública se autorizará al Poder Ejecutivo a que venda o afecte las mil leguas de que habla el Art. $4^{\circ}$, al precio mínimo de cinco mil pesos cada una.

Art. $9^{\circ}$. Los gastos que origine la presente Ley se imputarán a la misma.

Art. 10. Comuníquese al Poder Ejecutivo.

La compra de elementos bélicos y el monto destinado para ello debían permanecer secretos según las pautas de la época. Como ya se señaló, se trata de una de las materias tradicionalmente reconocidas como reservadas y que mantiene -probablemente incrementada- su vigencia en nuestros días. La autorización al Poder Ejecutivo también es una política habitual dado que aquél, por mandato de la Constitución nacional, es el "comandante en jefe de todas las Fuerzas Armadas de la Nación" y "dispone de las Fuerzas Armadas, y corre con su organización y distribución según las necesidades de la Nación"174.

Pero los aspectos más singulares se vinculan con el modo de financiar la compra de armamento: la venta de mil leguas de tierras fiscales y la de un ramal del Ferrocarril Andino. La cuestión será más clara apenas se repare en el momento político que atravesaba la Argentina. En efecto, PELLEGRINI había asumido la presidencia tras la renuncia de Miguel Ángel

${ }^{174}$ Artículo 99 incisos 12 y 14. 
JuÁREZ CELMAN (1896-1890) en medio de una grave crisis económica que enfrentó con la suscripción de un empréstito para el pago de la deuda externa, la emisión de bonos, la cancelación de las concesiones ferroviarias que no habían satisfecho las condiciones contractuales, el retiro de la oferta en el mercado europeo de la venta de 24.000 leguas de tierras en la Patagonia, etc. $^{175}$.

El Ferrocarril Andino había sido construido por el Estado con el propósito de unir las ciudades de Villa María, provincia de Córdoba con Villa Mercedes, provincia de San Luis ${ }^{176}$. La venta efectuada durante la presidencia de JUÁREZ CELMAN, constituyó una operación criticada al entregarse a manos de empresarios ingleses un ramal pujante ${ }^{177}$. Si hubiera tomado estado público que el producido de dicha operación estaba destinado a la compra de armamentos las críticas hubieran tenido otra intensidad. El contexto descripto explica, en parte, los motivos del secreto impuesto.

El monto de los gastos, en ese clima, también podía requerir el secreto. Baste con esta consideración. Recién asumida la presidencia PELLEGRINI reclamó un dramático apoyo financiero: \$15.000.000 para pagar la deuda externa que obtuvo de un grupo de comerciantes, banqueros y estancieros. El monto en armamentos representaba el 26,66 \% sobre \$4.000.000 que preveía la ley para la compra. La deuda externa, para entonces, ascendía a $\$ 204.000 .000^{178}$.

La otra fuente de financiación para la compra de armamentos estaba constituida por la autorización para la venta de 1000 leguas cuadradas de tierras fiscales. Aquí habrá que retener, por un lado, que PELLEGRINI había manifestado su oposición -siendo vicepresidente- a la política

\footnotetext{
${ }^{175}$ SÁBATO, Hilda, Historia de la Argentina 1852-1890, Buenos Aires, Siglo Veintiuno, 2012, p. 333.

${ }^{176}$ Los trabajos de construcción se iniciaron a principios de 1870 por la empresa de Juan Simmons y fueron totalmente financiados por el Estado. En octubre de 1873 se realizó la apertura de la primera sección, hasta Río IV. En 1875 se inauguró la línea hasta Villa Mercedes. Su expansión continuó: en 1882 llegó hasta la capital de San Luis y en 1885 hasta Mendoza y San Juan vinculando así las tres provincias cuyanas.

177 ARRABAL DE JAMENSON, Myriam, Había una vez un tren. Sesenta años del ferrocarril en San Juan. 1887-1947, San Juan, Editorial EFFHA, 2010, p. 26.

${ }_{178}$ MARICHAL SALINAS, Carlos, Historia mínima de la deuda externa de latinoamérica, 1820-2010, México, El Colegio de México, 2014, capítulo 5. Algunos autores consideran que existió en el período en "una verdadera fiebre de concesiones ferroviarias garantidas por el Estado y aprobadas, muchas veces, sin debate". Véase NAVARRO FLORIA, Pedro, "La nacionalización fallida de la Patagonia Norte, 1862-1904", en "Revista Quinto Sol" (Universidad Nacional de La Pampa), $N^{\circ} 7$, p. 61. La cita corresponde a la nota 9 en p. 73.
} 
de JuÁREZ CELMAN de vender tierras públicas en Europa. Al asumir la presidencia dejó sin efecto la oferta de venta de fundos en la Patagonia que aquél había efectuado. Pero, en secreto, era autorizado para venderlas. Si bien es cierto que la oferta de su antecesor era de 24.000 leguas y ahora sólo se trataba de 1.000, el antiguo sistema métrico puede hacer perder dimensión de sus alcances: 1.000 leguas cuadradas equivalen a 23.300 kilómetros cuadrados, esto es, poco más que la superficie de la provincia de Tucumán que tiene 22.524 kilómetros cuadrados.

b) Bolivia y las preferencias diplomáticas.

La nación extranjera que más leyes secretas generó fue Bolivia. Ni siquiera el Reino Unido cuya larga historia de acercamientos y alejamientos -incluido un conflicto bélico- con nuestro país concitó tanta preocupación legislativa por el secreto a poco que se advierta que la guerra por las Islas Malvinas motivó la sanción de sólo una ley secreta ${ }^{179}$.

La primera de una lista de 11 leyes que representan el $7,53 \%$ del total de las leyes secretas, fue dictada en 1967 bajo el gobierno militar de ONGANÍA. Para entonces Bolivia estaba presidida por el general René BARRIENTOS ORTUÑo y durante su mandato Ernesto "Che" Guevara fue apresado y muerto el 9 de octubre de 1967. Pocos días antes, el 22 de septiembre fue sancionada la ley 17459 que donaba al país limítrofe "armamentos, municiones y elementos de sostén logístico".

Durante 1969 se sancionaron 5 leyes secretas: en todas se donaron elementos bélicos y aunque en dos de ellas la donación al ejército boliviano consistió en caballos de silla, también recibió tres aviones Douglas DC-3. Para la fecha se mantenía un régimen militar en Bolivia encabezado en la ocasión por Alfredo OVANDO CANDíA.

La ley 18236 (1969) aprobó el "Acuerdo argentinoboliviano para el establecimiento de una misión naval Argentina en la República de Bolivia". Una de sus cláusulas establecía que la "Armada Argentina" brindaría cursos y asesoramientos al "Comando de la Fuerza Fluvial y Lacustre" boliviano.

\footnotetext{
${ }^{179}$ Ley secreta que lleva el número 22559 y fue sancionada pocos días antes del conflicto, el 30 de marzo de 1982.
} 
Es claro que este tratamiento especial acordado a Bolivia a la luz de las leyes secretas ahora difundidas coloca a dicho país como una suerte de socio oculto de la Argentina en el marco de la política latinoamericana $^{180}$. No pueden soslayarse al menos algunas circunstancias gravitantes. En las relaciones entre Argentina y Bolivia, el gas natural ha sido un elemento muy importante en los vínculos políticos, diplomáticos, económicos y comerciales y desde los primeros años de la década del setenta existe un acercamiento continuo por la comercialización de este recurso energético ${ }^{181}$. Un socio estratégico que, además, podía velar la frontera norte del país. Además, si se considera la existencia de una misión naval argentina permanente en La Paz y el compromiso de capacitación en esa disciplina de un país sin salida al mar, puede verse como la construcción de una alianza con un enemigo común: Chile. La disputa de nuestro país por la cuestión limítrofe por el Canal de Beagle estaba viva para entonces ${ }^{182}$. Bolivia, aún hoy, sigue reclamando una salida al mar pedido que la nación transandina desoye ${ }^{183}$.

\section{c) El caso del Paraguay.}

Paraguay también integró el grupo de países preferidos a la hora de sancionar leyes secretas. Si bien no alcanza el lugar de Bolivia, seis leyes se hicieron cargo de asuntos vinculados con aquel país y ello aconteció durante los gobiernos de ONGANíA (3), LANUSSE (2) y VIDELA (1). Para mantener

\footnotetext{
${ }^{180}$ En la ley secreta 19428 (1971) que consagra "las políticas nacionales secretas" se aspira a "asegurar y facilitar accesos permanentes de Bolivia al Atlántico, a través de nuestro litoral fluvial y vías de comunicación terrestre, a fin de neutralizar o debilitar la acción brasileña y fortalecer nuestra posición en el marco de la Cuenca del Plata" (Anexo, punto 9).

${ }^{181} \mathrm{CEPPI}$, Natalia, "La temática energética en las relaciones entre Argentina y Bolivia. Acuerdos y contrariedades por el gas natural", "Foro Internacional" (El Colegio de México), volumen L, No 1, p. 5.

${ }^{182}$ Cabe recordar que en diciembre de 1978 el conflicto estuvo a punto de derivar en un enfrentamiento armado. Los documentos secretos de los EEUU -difundidos en virtud de la Freedom of Information Act, el 4-4-2011- daban cuenta del movimiento de tropas de ambos países y de la inminencia de un conflicto armado (véase informe del CIA Operations Center, del 13-12-1978).

${ }^{183}$ Como consecuencia de la llamada Guerra del Pacífico (1879-1883), Chile incorporó territorios que correspondían a Perú y a Bolivia. Este último quedó en situación de mediterraneidad. El Tratado de Paz y Amistad del 20 de octubre de 1904 es un tratado de paz firmado por representantes de la República de Bolivia y la República de Chile con el fin de terminar el estado de guerra existente entre ambos países. Entre otras cuestiones para paliar la falta de salida al mar boliviana, Chile se comprometió a la construcción de un ferrocarril entre Arica y La Paz. Bolivia a lo largo del siglo XX mantuvo sus reclamos con relación a una salida al Océano Pacífico. La Corte Internacional de Justicia con sede en La Haya, tiene pendiente la decisión de la demanda promovida.
} 
la simetría con el punto anterior, se dirá que ello representa el 4,10\% sobre el total de leyes de carácter secreto.

La política vacilante y pendular del gobierno paraguayo en manos del general Alfredo STROESSNER, hizo que las relaciones bilaterales se centraran en una disputa entre la Argentina y Brasil por el comercio y navegación bilaterales. Los temas de los ríos Paraná, Paraguay y Uruguay, habían mantenido en vilo las gestiones de ambos países en virtud de una posible salida paraguaya al mar por el lado brasileño. Para impedir este tipo de viraje hacia la esfera de influencia brasileña, la Argentina firmó con las autoridades de Asunción en 1967, el tratado de Libre Navegación, creando una comisión mixta encargada de la fiscalización aduanera. Los gobiernos se fortalecieron y vincularon nuevamente a través de la visita que realizara ONGANÍA dos años más tarde a Paraguay con la finalidad de profundizar en temas relativos al turismo bilateral e inversiones para el relacionamiento de los sectores empresarios. El apoyo de la gestión de ONGANÍA por parte de STROESSNER, se hacía evidente. Sobre todo luego del incidente generado por el secuestro del cónsul paraguayo Waldemar SÁNCHEZ por parte del Frente Argentino de Liberación ( $F A L)$ para generar una especie de trueque entre el diplomático y dos miembros de dicho frente. En esta oportunidad, el general paraguayo convino en viajar a Argentina en 1970 como muestra del respaldo y amistad que lo unía con las autoridades argentinas. Finalmente el incidente tuvo una solución acorde a los reclamos paraguayos: el cónsul fue liberado sin intercambio posible. Desplazado ONGANía y habiendo asumido LANUSSE como presidente, éste viajó nuevamente a Asunción -antes, en abril de 1970, lo había hecho en su condición de Comandante en Jefe del Ejército Argentino para condecorar al mandatario paraguayo - para encontrarse con STROESSNER. Para el año 1973, la situación de la cuenca del Plata volvió a ser en punto central de las disputas ya que en el mes de marzo de ese año, el canciller argentino en Asunción entregó una nota a las autoridades paraguayas donde se dejaba claro que Argentina presentaba una reserva al proyecto hidroeléctrico paraguayo-brasileño por considerar que el mismo afectaría el caudal del río aguas abajo y disminuiría el potencial hidroeléctrico. Los 
reclamos no fueron aceptados por la cancillería paraguaya, como tampoco por la brasileña, acusando a Argentina de impedir las obras conjuntas ${ }^{184}$.

Es en este contexto que las autoridades argentinas resolvieron -secretamente- efectuar donaciones al país hermano. En algunos casos, de indudable contenido simbólico: la donación de caballos pura sangre. En otros de contenido bélico por tratarse de la entrega de 3 aviones. Sin embargo debe destacarse -como lo reconoce el mensaje de elevación del proyecto de ley- que "el material de vuelo de esta característica se halla en proceso de desprogramación" y que la donación se inspira en los "fraternos lazos existentes, forjados en aspiraciones e ideales comunes a nuestra tradición democrática y cristiana". En síntesis, gestos que muestran vocación de acercamiento pero que difícilmente, en los hechos, pudieron afectar el equilibrio de la región.

d) Los gastos reservados para los funcionarios públicos.

Una actividad reservada o secreta del Estado destinada a prevenir -por ejemplo- la evasión tributaria o el contrabando requiere para su implementación de recursos. Esos recursos deben seguir la misma suerte que la actividad, esto es, deberán ser reservados o secretos pues lo contrario probablemente frustraría los fines que el Estado pretende alcanzar. Sobre la base de esta lógica -admitida también en otras legislaciones- tempranamente se reconocieron estos gastos reservados.

El gobierno de la denominada Revolución Libertadora dictó un decreto secreto estableciendo que el otorgamiento de gastos reservados "comprende exclusivamente a los organismos que tengan servicios atinentes con la seguridad del Estado" 185 . Asimismo dispuso que los créditos de carácter reservado sólo podrían acordarse mediante partidas fijadas en la ley de presupuesto o por leyes especiales y que "anualmente, el Poder Ejecutivo incluirá en la cuenta de inversión los montos de los recursos y erogaciones" de carácter secreto. La Revolución Argentina dictó, a su vez, la ley secreta 18302 que precisó los alcances de aquel decreto. Por ello estableció "sólo podrán

\footnotetext{
${ }^{184}$ ZAPATA, Victoria, La revolución argentina (1966-1973) en SIMONOFF, Alejandro (Compilador), La Argentina y el mundo frente al bicentenario de la Revolución de Mayo : las relaciones exteriores argentinas desde la secesión de España hasta la actualidad, La Plata, Universidad Nacional de La Plata, 2010, ps. 272/273.

185 Lleva el número 5315/56.
} 
incluirse créditos destinados a atender gastos de carácter reservado y/o secreto, en el presupuesto de los siguientes organismos: Unidad de Organización - Presidencia de la Nación; Comando en Jefe del Ejército; Comando en Jefe de la Armada; Comando en Jefe de la Fuerza Aérea; Secretaría de Informaciones de Estado; Dirección Nacional de Gendarmería; Prefectura Nacional Marítima; Policía Federal y Dirección Nacional del Servicio Penitenciario Federal".

En 1984 bajo la presidencia de Raúl ALFONSín se restringieron considerablemente los organismos que podían realizar gastos reservados $^{186}$. A partir de 1992 con el presidente Carlos S. MENEM, la legislación comenzó a recorrer el camino inverso: el de la ampliación de los destinatarios de aquellos beneficios. El ejemplo más claro de esta tendencia está representado por el proyecto de Presupuesto de la Administración Nacional del año 1993 en el que el Poder Ejecutivo aspiraba a reformar la ley secreta 18032 e incorporar "al Poder Judicial de la Nación, Corte Suprema de Justicia, a los restantes Ministerios del Poder Ejecutivo Nacional no incluidos en el sistema a la fecha de la presente ley y a la Secretaría de Programación para la Prevención de la Drogadicción y la Lucha contra el Narcotráfico". Esto es una universalización de los beneficiarios: todos los jueces y todos los ministros del Poder Ejecutivo.

Sin embargo, el desvío más notable durante el gobierno de MENEM no consistió en la ampliación de los organismos que los recibían sino en el destino que se les asignó. Los gastos reservados terminaron incorporándose a la remuneración de funcionarios de alto rango como los ministros y secretarios del Poder Ejecutivo. Como se señaló, la encarga de la agencia de

\footnotetext{
${ }^{186}$ La ley 23110 en su artículo 35 modificó la ley secreta 18302: "Solamente podrán incluirse créditos destinados a atender gastos reservados o secretos según el decreto-ley secreto No. 5.315/56 para los siguientes organismos: Secretaría General de la Presidencia y Secretaría de Inteligencia del Estado (SIDE)". El artículo 37 de la misma derogó las leyes secretas 19867, 21627 y 22085 y suprimió las cuentas secretas de la Secretaría de Planificación, del Ministerio del Interior, de la Policía Federal, del Ministerio de Relaciones Exteriores, del Ministerio de Defensa, del Estado Mayor Conjunto, del Estado Mayor General del Ejército, de la Dirección Nacional de Gendarmería, del Estado Mayor General de la Fuerza Aérea y del Servicio Penitenciario Federal. Posteriormente. En el año 1986 el número de beneficiarios se elevó a tres: Presidencia de la Nación, Secretaría de Inteligencia de Estado y Ministerio de Defensa (art. 29 de la ley 23270). Mediante el artículo 37 de la ley 23410 se modifica nuevamente el art. 1 de la ley secreta 18302, incluyendo al Ministerio de Relaciones Exteriores. Desde 1987 y hasta 1992, fueron cuatro las jurisdicciones que gozaron de dicho beneficio: Presidencia de la Nación, Secretaría de Inteligencia de Estado, Ministerio de Defensa y Ministerio de Relaciones Exteriores.
} 
protección del medio ambiente la ingeniera María Julia ALSOGARAY, al ser imputada de enriquecimiento ilícito, reveló esta práctica.

Este extenso recorrido apunta a explicar la lucha legislativa y política que siempre ha existido por el reconocimiento de los gastos reservados. Las normas que los reconocían eran secretas. Hoy no lo son y están sometidos al control del Congreso. La ley cuyo debate se examinará, actuó de un doble modo: por un lado hizo pública a la citada ley secreta $18302^{187}$ y al decreto que le servía de antecedente. Pero además los derogó, estableciendo un nuevo sistema para la asignación de los gastos reservados. Hacia el futuro los únicos organismos que podrán percibirlos serán los "comprendidos en las leyes de Inteligencia Nacional, Seguridad Interior y Defensa Nacional". También se prohíbe "su utilización con propósitos ajenos a dicha finalidad", censurando así la práctica seguida durante la administración del presidente Menem. Y, por último, recupera y potencia el rol del Congreso pues el control de la rendición de dichos gastos "queda a cargo de la Comisión Bicameral de Fiscalización de los Organismos y Actividades de Inteligencia".

e) La protección de los jueces.

Con el propósito de juzgar "todos los delitos de índole federal que se cometan en el territorio nacional y lesionen o tiendan a vulnerar básicos principios de nuestra organización constitucional o la seguridad de las instituciones del Estado" se creó mediante la ley $19053^{188}$, la Cámara Federal en lo Penal de la Nación. Se trataba de un tribunal compuesto por nueve jueces distribuidos en tres salas y con una inusual competencia territorial en todo el país. Actuaban ante ella también tres fiscales. La validez constitucional de un cuerpo judicial de dichas características fue puesta en duda pues podía reputarse como una suerte de comisión especial vedada por la ley fundamental $^{189}$. En concreto, estaba integrada por tres salas con tres jueces

\footnotetext{
${ }^{187}$ Que todos los gobiernos desde 1969 conocían y en mayor o en menor medida, emplearon.

${ }^{188}$ Publicada en el Boletín Oficial del 1 de junio de 1971.

189 A la expresión técnica comisión especial se añadieron otras más explícitas en su descalificación: Camarón o Cámara de Terror. Un análisis en esta dirección puede encontrarse en el trabajo de SARRABAYROUSE OlIVEIRA, María José, "Familia judicial y dictaduras: la creación del fuero antisubversivo en la década del 70" en ÁGUILA, Gabriela, GARAÑo, Santiago y SCATIZZA, Pablo (Coordinadores), Represión estatal y violencia paraestatal en la historia reciente argentina, La Plata, Universidad Nacional de La Plata, Facultad de Humanidades y Ciencias de la Educación, 2016, p. 269. Una visión general de la actuación del Poder Judicial y de sus operadores puede encontrarse en la obra de BOHOSLAVSKY, Juan Pablo, ¿Usted
} 
cada una, tres fiscales y jurisdicción en toda la Nación. Individualmente los jueces tenían a su cargo llevar adelante una averiguación preliminar y, en conjunto, actuaban como un tribunal oral. Se trataba de una organización peculiar: cada uno de los nueve magistrados se desempeñaba como juez de instrucción según los turnos asignados y concluido el sumario se remitía la causa a los jueces de juicio que actuaban en pleno. Aun así funcionó hasta que asumió el gobierno Héctor J. CÁMPORA. La ley 20510 -sancionada el 27-5-1973, dos días después de su asunción- la dejó sin efecto e hizo cesar a todos sus integrantes. La rapidez con que se tomó la decisión de disolver dicho tribunal guarda directa relación con la importancia institucional que el anterior gobierno le asignaba ${ }^{190}$.

Sin embargo, el gobierno de LANUSSE les había otorgado a sus integrantes una protección secreta. En efecto, la ley 19111 sancionada con dicho carácter otorgaba a sus jueces una remuneración suplementaria. "Los señores jueces, fiscales y el personal de la Cámara Federal en lo Penal de la Nación creada por la ley 19053, cualquiera sea su jerarquía, percibirán mientras se encuentren revistando en el citado tribunal, una sobreasignación adicional del cuarenta por ciento (40\%) sobre la totalidad de sus remuneraciones por sueldo básico y compensación jerárquica". Ha sido un tema constante de ocultamiento, como se aprecia, las remuneraciones especiales de cierta clase de funcionarios. En este aspecto, no difiere de otras que hicieron lo mismo con los integrantes de la Policía Federal o las Fuerzas Armadas.

Pero esa protección resultaba insuficiente si el tribunal era disuelto porque al cesar en sus funciones también cesarían sus

también, doctor?: Complicidad de jueces, fiscales y abogados durante la dictadura, Buenos Aires, Siglo Veintiuno Editores, 2015.

${ }^{190}$ La relevancia de este cuerpo es discutida. Por una parte, los que lo reivindican señalando que permitía la persecución del terrorismo con la ley en la mano. De otra, quienes consideran que su creación constituyó en un aspecto relevante del proceso de reforzamiento del aparato represivo del Estado, característico de los años setenta. El análisis de su funcionamiento y actividad, sumado a la indagación en sus condenas y fallos muestran una profunda contradicción: la represión de las fuerzas populares y de izquierda, por parte de un tribunal de carácter inconstitucional, creado por una dictadura militar, se llevaba adelante en nombre de la defensa de la Constitución y de las instituciones democráticas, inexistentes en esa etapa. Por otra parte, un aspecto que se destaca es la creciente utilización del concepto de subversión, tanto en la legislación como en los fallos del Poder Judicial, para referirse y reprimir a las organizaciones revolucionarias de la época. Véase D’ANTONIO, Débora y EIDELMAN, Ariel, "El fuero antisubversivo y los consejos de guerra contra civiles en la Argentina de los años 70" en "Estudios Interdisciplinarios de America Latina y el Caribe" (Tel Aviv), Año 2016, vol. 27 p. 7. 
remuneraciones. Por ello previó una contingencia que se concretó: que un gobierno constitucional la disolviese. El artículo 2 de esta ley secreta establecía: "En el caso de que por cualquier motivo la citada Cámara Federal perdiere su competencia o fuere disuelta, los señores jueces que la integran pasarán a constituir nuevas salas en la Cámara Nacional de Apelaciones en lo Criminal y Correccional de la Capital Federal. Los señores fiscales de cámara pasarán a actuar ante dicho Tribunal y los funcionarios de ley y el personal administrativo y técnico y de maestranza y servicio será redistribuido por la Corte Suprema de Justicia de la Nación de acuerdo con las necesidades de los distintos tribunales federales y ordinarios de la Capital. Producido este evento cesará la liquidación de la sobreasignación".

De este modo, sin difusión, se beneficiaba a los jueces para emplear las palabras de la ley- con una sobreasignación y si el tribunal que integraban desaparecía por mandato de otra ley, mantendrían sus cargos distribuidos en otros tribunales. Esto es gozarían de una inamovilidad en sus empleos equivalente o superior a la que otorga la Constitución que, para entonces, el gobierno militar no observaba.

\section{RECAPITULACIÓN}

El examen de las publicaciones oficiales revela que las leyes secretas sumaban 146, que comprendían más de un siglo y los temas más diversos -desde compras de armas hasta obsequios entre presidentes. Fueron sancionadas tanto por gobiernos democráticos como militares, aunque en proporción muy diversa. Los primeros fueron los responsables de sólo un $20 \%$ aproximadamente, mientras que el $80 \%$ restante se gestó en los regímenes militares.

Ese largo recorrido que comenzó a fines del siglo XIX en la presidencia de PELLEGRINI en 1891 y se prolongó hasta octubre de 1983, revela que el secreto acompaña la historia institucional Argentina. Variaron los motivos del secreto o las frecuencias con que se lo empleaba pero siempre se consideró que debía existir un núcleo duro de decisiones legislativas 
reservadas. Entre éstas regularmente aparecieron las cuestiones vinculadas con la seguridad, la defensa o la política exterior.

Este recorrido registra, sin embargo, algunos puntos singulares. El primero de ellos, sin dudas, está constituido por una olvidada ley del Congreso -durante la segunda presidencia de Julio A. RocA- que levantaba el secreto que se había impuesto sobre las anteriores sancionadas con dicho carácter. Esta práctica se adormeció y sólo despertó más de un siglo más tarde en 2006. El segundo, tiene que ver con una suerte de desenfreno encabezado por los gobiernos militares que ampliaron el catálogo de cuestiones secretas y lo emplearon con habitualidad. Aunque debe tenerse presente que durante los regímenes de facto $-\mathrm{y}$ por los motivos que ya se explicaron- toman el nombre de leyes disposiciones del Poder Ejecutivo frente a un Congreso clausurado. Si se desagregan éstas el resultado es un poder legislativo que usó con moderación el instrumento del secreto.

A la hora del debate en el Congreso, los diputados y senadores conocían este extenso listado de leyes sancionadas como secretas y sabían de sus contenidos. Es decir, podían calibrar con precisión qué se difundía y las probables consecuencias de ello porque la decisión sobre la publicidad recaía en un número limitado de leyes. El modo en que ello gravitó para defender las posiciones que tomaron podrá verse en el capítulo siguiente. 


\section{CAPÍTULO IV \\ EL DEBATE PARLAMENTARIO}

\section{EL MARCO HISTÓRICO Y POLÍTICO DEL DEBATE}

1. En las elecciones presidenciales del 27 de abril de 2003 , el "Frente para la Victoria" con la fórmula KIRCHNER-SCIOLI obtuvo el 22,24\% de los votos. La "Alianza Frente por la Lealtad -UCD" encabezada por el binomio MENEM-ROMERO obtuvo el 24,45\% ${ }^{191}$. La legislación electoral argentina establece que en dichos casos se debe disputar una segunda vuelta, denominada ballotage ${ }^{192}$.

Ésta debía llevarse a cabo el 18 de mayo de 2003. Las encuestas habituales en estas situaciones otorgaban entre un 60 y $70 \%$ de intención de voto para la primera. El ex presidente MENEM, tras una larga cadena de rumores, anunció el 14 de mayo su decisión de renunciar a la candidatura $^{193}$. El 25 de mayo de 2003 asumió como presidente de la Nación Néstor C. KIRCHNER.

En su discurso de asunción ante la Asamblea Legislativa que empleamos aquí para sintetizar los propósitos confesados de su gobierno, dijo:

A comienzos de los 80 , se puso el acento en el mantenimiento de las reglas de la democracia y los objetivos planteados no iban más allá del aseguramiento de la subordinación real de las Fuerzas Armadas al poder político. La medida del éxito de aquella etapa histórica, no exigía ir más allá de la preservación del Estado de derecho, las continuidades de las autoridades elegidas

\footnotetext{
${ }^{191}$ Los datos aparecen en la publicación oficial Recorriendo elecciones de la Dirección Nacional Electoral.

${ }^{192}$ El Código Electoral Nacional (arts. 149 y 150) dice que: "Resultará electa la fórmula que obtenga más del cuarenta y cinco por ciento (45\%) de los votos afirmativos válidamente emitidos: en su defecto, aquella que hubiere obtenido el cuarenta por ciento (40\%) por lo menos de los votos afirmativos válidamente emitidos y además existiere una diferencia mayor de diez puntos porcentuales respecto del total de los votos afirmativos válidamente emitidos, sobre la fórmula que le sigue en número de votos". "Si ninguna fórmula alcanzare esas mayorías y diferencias de acuerdo al escrutinio ... se realizará una segunda vuelta".

193 "En caso de renuncia de los dos candidatos de cualquiera de las dos fórmulas más votadas en la primera vuelta, se proclamará electa a la otra", dice el art. 155 del cuerpo legal mencionado.
} 
por el pueblo. Así se destacaba como avance significativo y prueba de mayor eficacia la simple alternancia de distintos partidos en el poder.

En la década de los 90, la exigencia sumó la necesidad de la obtención de avances en materia económica, en particular, en materia de control de la inflación. La medida del éxito de esa política, la daba las ganancias de los grupos más concentrados de la economía, la ausencia de corridas bursátiles y la magnitud de las inversiones especulativas sin que importara la consolidación de la pobreza y la condena a millones de argentinos a la exclusión social, la fragmentación nacional y el enorme e interminable endeudamiento externo. Así, en una práctica que no debe repetirse, era muy difícil de distinguir la solución pragmática de la cirugía sin anestesia. Se intentó reducir la política a la sola obtención de resultados electorales; el Gobierno, a la mera administración de las decisiones de los núcleos de poder económico con amplio eco mediático, al punto que algunas fuerzas políticas en 1999, se plantearon el cambio en términos de una gestión más prolija, pero siempre en sintonía con aquellos mismos intereses. El resultado no podía ser otro que el incremento del desprestigio de la política y el derrumbe del país.

En este nuevo milenio, superando el pasado, el éxito de las políticas deberá medirse bajo otros parámetros en orden a nuevos paradigmas. Debe juzgárselas desde su acercamiento a la finalidad de concretar el bien común, sumando al funcionamiento pleno del Estado de derecho y la vigencia de una efectiva democracia, la correcta gestión de gobierno, el efectivo ejercicio del poder político nacional en cumplimiento de trasparentes y racionales reglas, imponiendo la capacidad reguladora del Estado ejercidas por sus organismos de contralor y aplicación $^{194}$.

2. Los primeros pasos del gobierno en lo que aquí interesa no traicionaron esta última promesa. Una de las decisiones más celebradas fue la sanción de un decreto ${ }^{195}$ de acceso a la información pública. Allí se reconoció que "constituye un objetivo de esta administración fortalecer la relación entre el Estado y la sociedad civil, en el convencimiento de que esta alianza estratégica es imprescindible para concretar las reformas institucionales necesarias para desarrollar una democracia legítima, transparente y eficiente". Afirmó también que "para lograr el saneamiento de las instituciones debe darse un lugar primordial a los mecanismos que incrementan la transparencia de los actos de gobierno, a los que permiten un igualitario acceso a la información y a

\footnotetext{
194 Desde el inicio mismo aparecía el discurso sobre la transparencia.

${ }^{195}$ Es el 1172/2003 que extendió su vigencia hasta 2016 cuando -bajo la presidencia de Mauricio MACRI- se sancionó la ley 27275, llamada de Acceso a la Información Pública.
} 
los que amplían la participación de la sociedad en los procesos decisorios de la administración".

El acceso amplio a la información pública era visto, entonces, como un instrumento indispensable para investigar y sancionar los actos de corrupción de la década anterior. Tiempo después, también se advirtió su potencia para averiguar el destino de las personas desaparecidas forzosamente durante el gobierno de facto iniciado en $1976^{196}$ y para colaborar en las causas judiciales abiertas por los atentados terroristas contra la embajada de Israel en Buenos Aires y la sede social de la comunidad judía $(\mathrm{AMIA})^{197}$.

3. La cuestión de las leyes y decretos secretos era objeto de debate para entonces. Ocurría que el affaire ALsOGARAY ocupaba lugares centrales en los medios de comunicación. La extensa lista de hechos de corrupción que se atribuían a la administración encabezada por MENEM se detenía singularmente en dicha funcionaria que en sus defensas judiciales y mediáticas comenzó a difundir la existencia de leyes y decretos secretos que permitían el pago de sobresueldos a los funcionarios. De esa manera podía justificar el incremento de su patrimonio. Una carta de lectores suscripta por ella y aparecida en el diario "La Nación" sintetiza el panorama:

En noviembre de 1991 fui designada Secretario de Recursos Naturales y Ambiente Humano (organismo conocido como Secretaría de Medio Ambiente). Comencé, entonces, a concurrir a las reuniones del gabinete nacional, al que pertenecen los ministros y secretarios de la Presidencia de la Nación y suelen asistir el vicepresidente de la Nación, y algunos diputados y senadores.

Simultáneamente, fui convocada por el entonces secretario general de la Presidencia Dr. Eduardo BAUZÁ, a una reunión en su despacho de la Casa Rosada, donde me comunicó que mensualmente recibiría una suma de dinero acorde a mi situación de secretario de la Presidencia. Dicho dinero, que según me explicó provenía de fondos secretos votados por el Congreso de la Nación para reparticiones del Poder Ejecutivo, estaban destinados a

\footnotetext{
${ }^{196}$ El Poder Ejecutivo ordenó desclasificar "toda aquella información y documentación vinculada con el accionar de las Fuerzas Armadas durante el período comprendido entre los años 1976 y 1983, así como a toda otra información o documentación, producida en otro período, relacionada con ese accionar" (decreto 4/2010, énfasis añadido).

${ }_{197}$ Tardíamente el decreto 395/2015 ordenó la desclasificación de los documentos que tuvieran vinculación con ese atentado, ocurrido el 18 de julio de 1994.
} 
complementar la remuneración de los funcionarios de nivel político y a cubrir otros gastos.

Ante mi pregunta sobre la operatoria de distribución, el ministro me dijo que quedaba a mi criterio pues se trataba de un monto del que no se rendía cuentas; el sobre con los fondos sería entregado mensualmente a la persona que yo designara al efecto.

La suma percibida por los Secretarios era de $\$ 40.000$ y, hasta donde supe por comentarios en gabinete, la de los ministros no bajaba de $\$ 100.000$ (suma posteriormente reducida a la mitad) según las mismas fuentes ${ }^{198}$.

Tiempo después, en reunión de gabinete, el ministro de Economía, Domingo CAVALLO, se dirigió a los presentes en su totalidad y anunció la obligación de declarar el sobre tanto ante la AFIP como en las declaraciones juradas anuales personales que los funcionarios entregaban al escribano mayor de Gobierno.

Nadie levantó la mano. Nadie preguntó ‘¿de qué sobre hablan?’ Desde el Presidente de la Nación hasta los legisladores presentes dieron muestra de tener en claro el tema. Yo cumplí la instrucción recibida: distribuí el importe entre los funcionarios de mi área y les pedí que lo declararan ${ }^{199}$.

En los albores de la presidencia de Néstor KIRCHNER se dio -como se expuso- un notable impulso a la difusión de los actos públicos y tras dos años de mandato, el Congreso discutía la eliminación de las leyes secretas. El país parecía encaminarse a instituciones más transparentes. Nuestra lupa examinará ese debate en los capítulos siguientes. Éste está destinado a presentarlo a través de los discursos de los diputados y senadores.

\section{LA COMPOSICIÓN DE LA CÁMARA DE DIPUTADOS Y DE SENADORES}

1. Del modo más esquemático mostraremos la integración de cada una de las cámaras que componen el Congreso de la Nación.

a. La Cámara de Diputados de la Nación está formada por 257 diputados. El número de diputados necesarios para obtener la media sanción de las leyes es de 129. En el año $2006^{200}$ una sola fuerza -el Frente

\footnotetext{
${ }^{198}$ Sumas que, para la fecha, equivalían a dólares estadounidenses.

${ }^{199}$ En el ejemplar del 23 de abril de 2005.

${ }^{200}$ El proyecto se votó el 16 de agosto de 2006
} 
para la Victoria- contaba con 117. Las alianzas frecuentes le permitían alcanzar con facilidad el número necesario para imponer su criterio.

\begin{tabular}{|l|l|}
\hline Frente para la Victoria & 117 \\
\hline Unión Cívica Radical & 36 \\
\hline Peronista Federal & 20 \\
\hline Justicialista Nacional & 15 \\
\hline A.R.I. & 13 \\
\hline PRO & 11 \\
\hline Partido Socialista & 5 \\
\hline Partido Nuevo & 4 \\
\hline Movimiento Popular Neuquino & 4 \\
\hline Partido Unidad Federalista & 2 \\
\hline Fuerza Republicana & 2 \\
\hline P. Renovador (Salta) & 2 \\
\hline Frente Cívico y Social & 2 \\
\hline Frente Cívico por Santiago & 2 \\
\hline Concertación Entrerriana & 17 \\
\hline Bloques unipersonales & \\
\hline
\end{tabular}

b. La Cámara de Senadores de la Nación está formada por está compuesto por 72 senadores; tres por cada una de las 23 provincias y tres por la Ciudad Autónoma de Buenos Aires. Con 37 votos puede dar media sanción a los proyectos de ley. Hay que tener presente, sin embargo, que para ciertos actos -por ejemplo, el otorgamiento del acuerdo a los candidatos para integrar la Corte Suprema de Justicia de la Nación- se requiere un quorum específico que equivale a las dos terceras partes de los miembros de la Cámara. El Partido Justicialista en el año $2005^{201}$ podía imponer su criterio sin necesidad de alianzas.

201 El proyecto se votó el 15 de junio de 2005. 


\begin{tabular}{|l|l|}
\hline Partido Justicialista & 42 \\
\hline Unión Cívica Radical & 13 \\
\hline Movimiento Popular Neuquino & 2 \\
\hline Fuerza Republicana (Tucumán) & 2 \\
\hline Frente Cívico y Social (Catamarca) & 2 \\
\hline Justicialista de San Luis & 2 \\
\hline Radical Independiente & 1 \\
\hline Radical Rionegrino & 1 \\
\hline Producción y Trabajo (San Juan) & 1 \\
\hline P. de la Victoria & 1 \\
\hline P. Renovador (Salta) & 1 \\
\hline Federalismo y Liberación (La Rioja) & 1 \\
\hline P. Socialista & 1 \\
\hline Vecinalista - Partido Nuevo & 1 \\
\hline
\end{tabular}

\section{EL PROYECTO DE LEY Y SU TRAYECTORIA}

En lo que sigue describiremos el contenido sustancial de los discursos de los legisladores que se registraron en cada una de las Cámaras. Lo haremos siguiendo el orden en que fueron pronunciados, comenzando por la Cámara de Senadores en la que tuvo inicio el trámite legislativo ${ }^{202}$.

\section{La discusión en la Cámara de Senadores.}

Aquí el tratamiento fue sobre tablas ${ }^{203}$. Existían varios proyectos $^{204}$ vinculados al tema y se decidió unificarlos pues los senadores

\footnotetext{
${ }^{202}$ Seguimos para efectuar las transcripciones las versiones taquigráficas corregidas por la Dirección de Taquígrafos.

${ }^{203}$ La mayoría de los proyectos que llegan al Senado se tratan en las comisiones antes de ser considerados en el recinto. Pero en algunas ocasiones, el Senado decide, mediante votación, que un proyecto sea tratado sin que pase previamente por las comisiones. Ese es el caso de tratamiento sobre tablas.

${ }^{204}$ Se detallan los proyectos de ley existentes. Hay matices y diferencias entre ellos que fueron dejados de lado cuando los senadores de los distintos partidos suscribieron un dictamen común que colocaba el acento en la publicación de las leyes que eran secretas y en la
} 
acordaron que entre ellos no existían diferencias sustanciales. El discurso inicial estuvo a cargo de la senadora Cristina FERNÁNDEZ DE KIRCHNER ${ }^{205}$ que presidía la Comisión de Asuntos Constitucionales. Tras ella hicieron uso de la palabra los senadores Rodolfo H. TERRAGNO ${ }^{206}$, Mario A. LOSADA ${ }^{207}$, Ernesto R. SANZ ${ }^{208}$, Sonia M. Escudero ${ }^{209}$, Carlos A. Rossi ${ }^{210}$ y Jorge A. AgÚNDEZ ${ }^{211}$.

Destacaremos sólo aquellos relevantes con el objeto de nuestra investigación; de lo contrario, el capítulo se convertiría en una larga y tediosa transcripción de discursos. $Y$ desde dicha perspectiva se expondrán sólo los discursos de FERNÁNDEZ DE KIRCHNER y SANZ. El primero informa los lineamientos del proyecto, el segundo procura aportar precisiones para su formulación. Ambos senadores dialogan y exponen sus razones con la finalidad de que se consagre la mejor redacción del texto legislativo.

1.1. La senadora FERNÁNDEZ DE KIRCHNER hizo uso de la palabra en primer lugar. Refirió que varias iniciativas se habían presentado en el Senado y que la suya tenía un propósito unificador y superador. Destacó que proponía la derogación de los dos pilares fundamentales del sistema que podría denominarse como de leyes secretas y reservadas en la República Argentina, y que está dado por los decretos 5.315/56 —dictado por el gobierno que interrumpió el gobierno constitucional del ex presidente PERÓN, o sea, la

prohibición de sanción hacia el futuro. S.1179/04 (senadora CONTI) "Proyecto de ley disponiendo la publicación de las leyes de carácter secreto y otras cuestiones conexas"; S.1202/04 (senador LOSADA) "Reproduce el proyecto de ley suspendiendo el dictado de leyes de carácter secreto y dando a publicidad las ya sancionadas"; S.1303/04 (senadora IBARRA) "Proyecto de ley disponiendo la publicación de las leyes secretas y reservadas"; S.3539/04 (senadora GIUSTI) "Proyecto de ley creando en el ámbito del poder legislativo la comisión bicameral permanente de análisis y administración de normativa secreta y reservada"; S.1251/05 (senadora NEGRE DE ALONSO) "Proyecto de ley dejando sin efecto el carácter secreto de la Ley "S" 18302 y del Decreto Ley "S" 5315/56, relacionada con el pago de sobresueldos a funcionarios públicos con fondos reservados"; S.1419/05 (senadora PERCEVAL) "Proyecto de ley sobre publicación de leyes sancionadas con carácter secreto" y S. 1622/05 (senador GUINLE) "Proyecto de ley disponiendo la publicación de toda ley, decreto ley, decreto, tratado internacional y demás instrumentos normativos que revistan el carácter de secreto o reservado y la creación de una comisión bicameral".

${ }^{205}$ En representación de la provincia de Santa Cruz; Partido Justicialista (1995-2005) y en representación de la provincia de Buenos Aires; Alianza Frente para la Victoria (2005-2007).

${ }^{206}$ En representación de la Ciudad Autónoma de Buenos Aires; Unión Cívica Radical (20012007).

${ }^{207}$ En representación de la provincia de Misiones; Unión Cívica Radical (1989-2005).

${ }^{208}$ En representación de la provincia de Mendoza; Unión Cívica Radical (2003-2009 y 20092015).

${ }^{209}$ En representación de la provincia de Salta; Frente Justicialista para la Victoria (2001-2007 y 2007-2013).

${ }^{210}$ En representación de la provincia de Córdoba; Alianza Frente Nuevo (2003-2009).

${ }^{211}$ En representación de la provincia de San Luis; Unión Cívica Radical (1995-2001 y 20012005). 
autodenominada Revolución Libertadora - y 18.302/69 - este último dictado por la autodenominada Revolución Argentina, con el general ONGANíA como presidente de la Nación. En primer lugar enfatizó en la necesidad de limitar la discrecionalidad en el empleo de los llamados gastos reservados y de someterlos siempre al control del Congreso. En segundo lugar, tras mostrar su asombro por la existencia de leyes secretas -"hay algunas leyes que en realidad nadie sabe por qué fueron decretadas secretas, por ejemplo, una vinculada con la compra de vajilla para la residencia de Olivos"- propició su publicación y su prohibición hacia el futuro.

1.2. El senador SANZ constituyó el principal intelocutor y propició algunas modificaciones. Adhirió a la idea de que era de fundamental importancia dejar sin efecto el carácter reservado de toda la legislación. Sin embargo -advirtió- los decretos de necesidad y urgencia debían ser incluidos por revestir carácter legislativo. En su respuesta -aceptada por el Cuerpo- la senadora FERNÁNDEZ DE KIRCHNER dijo que "la publicidad de los decretos reservados y secretos que existan en el ámbito del Poder Ejecutivo es una decisión de ese poder" y que "el instrumento del Poder Ejecutivo es el decreto y nosotros no podemos derogar un decreto si no lo hace el Ejecutivo mediante una norma similar".

1.3. Otras intervenciones de los senadores fueron menos relevantes. TERRAGNo adhirió a la propuesta de FERNÁNDEZ DE KIRCHNER formulando una interesante observación: "por si subsistiera la duda, yo creo que no hay que preguntarse cómo derogar una ley que no se conoce: lo que hay que preguntarse es cómo puede regir una ley que no se conoce". LOSADA siguió el mismo camino; ESCUDERO propició como SANZ la inclusión de los decretos de necesidad y urgencia y Rossı y AGUNDEZ hicieron uso de la palabra pero sólo para sumarse a la propuesta de FERNÁNDEZ DE KIRCHNER sin efectuar mayores consideraciones.

1.4. Sobre 72 miembros que conforman el cuerpo asistieron a la sesión estudiada 53 senadores que representaron el $73,6 \%$ del cuerpo. Hubo 53 votos positivos -unanimidad-a favor de la publicación de las leyes secretas. 
2. La discusión en la Cámara de Diputados.

Aquí la discusión fue más intensa. El número de diputados que hicieron uso de la palabra y la variedad de opiniones, tornan algo más compleja la tarea de síntesis.

2.1. El diputado Juan Manuel URTUBEY ${ }^{212}$ manifestó su acuerdo con el proyecto aprobado el Senado, que deja sin efecto el carácter secreto y reservado de toda ley que hubiera sido sancionada en esa condición. Recordó que el texto tuvo "un abrumador apoyo" en el Senado de la Nación y que con la derogación de la ley secreta 18.302 y del decreto ley secreto 5.315/56, los gastos reservados sólo se emplearán para cuestiones de inteligencia o de seguridad nacional y que esos fondos estarán sujetos a un sistema de control mediante la intervención de la Comisión Bicameral de Fiscalización de los Organismos y Actividades de Inteligencia. Asumió también la defensa de los límites trazados en el proyecto -y resistidos por la oposicióny estimó que el Congreso no podía autorizar la difusión de los decretos del Poder Ejecutivo.

En esa misma línea se manifestó la diputada Diana $\mathrm{CONTI}^{213}$ que efectuó un llamado a los restantes bloques de la Cámara para que abandonaran su oposición a algunas partes del proyecto. Reconoció que la iniciativa legislativa constituía "un avance institucional". La afirmación es morigerada más adelante cuando añadió que "no sé si muy significativo, puesto que hoy en día a nadie se le ocurriría en la Argentina sancionar leyes secretas" y que en la acualidad son "de índole puramente histórica" .

El pedido de la diputada CONTI para unificar el criterio fue rechazado por varios diputados. Alejandro NiEVA ${ }^{214}$ denunció que se estaba asistiendo "a un espasmo de transparencia; hoy se publican las leyes secretas, pero ello es absolutamente insuficiente. De la simple lectura del proyecto en debate se desprende que quedan fuera los decretos secretos; y en el análisis de la legislación comparada y de la de nuestro país, advertimos que prácticamente la totalidad de las normas secretas emanan de los despachos del Poder Ejecutivo y no del Congreso. Desde 1983 el Parlamento no ha

\footnotetext{
212 Partido Justicialista (1999-2007).

${ }^{213}$ Frente para la Victoria (2005-2009, 2009-2013 y 2013-2017).

214 Unión Cívica Radical (1993-1997, 1997-2001, 2001-2005 y 2005-2009).
} 
sancionado ni una sola ley secreta". El problema es que "estamos olvidándonos de los decretos reservados, que es lo más importante. Sobre ello ni una sola palabra se ha dicho, sin perjuicio de que la señora diputada CoNTI señaló que hay más de cinco mil decretos secretos. Todos estos seguirán siendo secretos". Pero -también morigerando su discurso- reconoció que "un Estado moderno necesita salvaguardar la República y la sociedad. Por ejemplo, algunas cuestiones relativas a investigaciones policiales, lucha antiterrorista, temas científicos, financieros, etcétera, sin duda requieren ser manejadas con determinada reserva a fin de no producir un daño a la sociedad. No estamos diciendo que inmediatamente debemos descorrer el velo para que todo sea transparente, porque eso no sirve y hacerlo no sería serio. Sin embargo, existen decretos secretos que sí deberían conocerse, de la misma manera que el criterio utilizado por el funcionario para emitirlos".

Los argumentos del diputado J. Adrián PÉREZ ${ }^{215}$ se unieron a los de NiEVA. "Los miembros informantes sostuvieron que este proyecto de ley constituye uno de los avances institucionales más importante de los últimos tiempos, y yo quiero demostrar que esta iniciativa es puro maquillaje". Apuntó al contenido histórico de las leyes que se difundirían y concluyó en que "no alcanza con la publicación de las leyes. Es más, diría que a esta altura es intrascendente la publicación de las leyes. Si verdaderamente queremos que la sociedad sepa, tenemos la obligación moral de publicar y poner en conocimiento las decisiones secretas del Poder Ejecutivo que permitieron los más vastos ilícitos de la administración pública nacional".

Finalmente el diputado Pablo TONELLI ${ }^{216}$ mostró su acuerdo en lo que respecta al principio de publicidad de los actos de gobierno. Pero a su juicio el proyecto en consideración tiene un exceso y un defecto. El exceso tiene que ver con la prohibición de que en el futuro el Congreso sancione leyes secretas. Admitió que pueden existir razones que "perfectamente pueden requerir la sanción de una ley secreta en el futuro" como aquellas vinculadas con la defensa, la seguridad o de relaciones exteriores. El defecto -enfatizó"es dejar fuera del proyecto de ley otras normas, como los decretos, que además en esta materia son muchísimo más abundantes que las leyes, y en la

${ }^{215}$ Coalición Cívica (2003-2007, 2007-2011) y Frente Renovador (2013-2015).
${ }^{216}$ Propuesta Republicana (2005-2009, 2011-2015 y 2015-2019). 
actualidad mucho más trascendentes que ellas por el contenido que tienen y por la materia que resuelven".

2.2. Sobre 257 miembros que conforman el cuerpo asistieron a la sesión estudiada, 187 diputados que representaron el 72,76\% del cuerpo. Hubo 171votos por la afirmativa, esto es, a favor de la publicación de las leyes secretas; 10 por la negativa y se registraron 5 abstenciones.

\section{EL DEBATE EN LA PRENSA.}

Como acontece en las democracias contemporáneas, el debate no sólo se registró en los recintos del Congreso. Los medios de comunicación y la prensa en particular acompañaron la discusión pública. Antes y durante el debate propiamente dicho informaron detalladamente sobre la situación. Con el propósito de mostrar el modo en que lo hicieron, emplearemos los artículos aparecidos en los diarios Clarín y Página 12. Estos periódicos representan líneas editoriales y estilos periodísticos diferentes entre sí y su examen conjunto brindará un panorama más completo.

Para el mejor examen de la cuestión, distinguiremos tres momentos. La primera etapa tiene que ver con las versiones iniciales sobre la existencia de leyes secretas. Como ya se dijo, la causa seguida a María Julia AlsogARAY había disparado las versiones sobre la existencia de disposiciones secretas. No era claro para entonces si se trataba de leyes o decretos. Se informaba con pocas precisiones y los cronistas, al comienzo, dejaban entrever cierta incredulidad que fueron abandonando cuando, con mayor rigor, investigaron la cuestión. La segunda, tiene que ver con el tratamiento del proyecto de ley en el Senado de la Nación y su media sanción. Finalmente y tras un extenso hiato, la tercera se vincula con la aprobación en la Cámara de Diputados y la promulgación de la ley que eliminó el secreto y dispuso la publicidad de las leyes que habían sido sancionadas con ese carácter.

1. Las versiones iniciales.

Tempranamente -en 1995- el diario Página 12 había llevado adelante una investigación en la que había determinado que el Ministro de Economía -en el gabinete del Presidente Menem- Domingo F. Cavallo había percibido sumas de dinero adicionales a su salario como funcionario. 
Había llegado a dicha conclusión tras examinar sus declaraciones juradas patrimoniales. La noticia daba cuenta de la existencia de la ley secreta 18.302 que permitía el empleo de fondos reservados ${ }^{217}$. Tras ello, años después, volvió sobre el tema con una nueva publicación ${ }^{218}$.

El cobro de sobresueldos mediante fondos reservados por parte de los funcionarios del menemismo había tomado estado público a través de distintas versiones periodísticas aunque Página 12 se había anticipado a otros medios. Ahora advertía que el pago de sobresueldos constituía un sistema "perverso, ilegal, antijurídico y delictivo" y que los procesos judiciales en trámite deberían desembocar en el enjuiciamiento y eventual condena para centenares de funcionarios que ocuparon cargos políticos jerárquicos durante la administración de MENEM. Pero no ocultaba que también funcionarios del gobierno de Néstor C. KIRCHNER podrían también estar involucrados.

Días después bajo el título Las leyes secretas ahora son inconstitucionales volvía sobre el tema e informaba que una de esas leyes secretas - la 18.302, empleada para justificar el pago de sobresueldos a funcionarios en la década menemista- había sido declarada inconstitucional ${ }^{219}$. En esa misma fecha publicada un breve anexo con las leyes secretas que -a la luz de lo que luego se difundió- eran unas pocas.

Contemporáneamente Clarín daba cuenta de la existencia de más de veinte proyectos para derogar las leyes secretas ${ }^{220}$ y seis días después difundía una nueva nota ${ }^{221}$ bajo el título Leyes secretas: desde compra de armas hasta donación de caballos-. Señalaba que "son 141 las leyes que se dictaron en sigilo desde 1891, que son conocidas sólo por quienes deben aplicarlas pero no por la sociedad sobre la que recaen sus consecuencias. Muchas tienen, a esta altura, sólo valor histórico, pero el Gobierno por ahora no se ha decidido a hacerlas públicas, pese a que un fallo judicial las declaró inconstitucionales esta semana”.

\section{El debate en el Senado.}

\footnotetext{
${ }^{217}$ El 14 de febrero de 1993.

218 El 8 de mayo de 2005.

219 El 12 de mayo de 2005.

${ }^{220}$ El 9 de mayo de 2005.

${ }^{221}$ El 15 de mayo de 2005.
} 
Clarín informó de modo lacónico que el Senado había aprobado y remitido a la Cámara de Diputados un proyecto que derogaba las normas creadas por las dictaduras de Pedro Eugenio ARAMBURU y Juan Carlos ONGANÍA que fueron usadas como amparo legal para el pago de sobresueldos a funcionarios públicos. Además -destacó- le quitó el carácter secreto a otras 141 leyes, que deberán ser publicadas en el Boletín Oficial en un plazo de hasta 60 días $^{222}$.

Página 12 lo hizo con más detalle bajo el título El Senado dio el primer paso para que no existan más leyes secretas. Dijo que el cuerpo resolvió por unanimidad y con poco debate. Le atribuyó la iniciativa legislativa a Cristina FERNÁNDEZ DE KIRCHNER, aunque ello no había sido así pues varios senadores habían presentado proyectos similares que se trataron de modo unificado. Subrayó que algunas de las normas secretas "se utilizaron como andamiaje justificatorio para el cobro de sobresueldos durante la década menemista". Reprodujo textualmente varios pasajes del discurso de la senadora y, naturalmente, uno en el que la legisladora reconocía la actuación del periódico: "En esta Argentina entre el parecer y el ser, parece que nadie leyó estas dos leyes publicadas en un matutino porteño: Página/12. Los demás medios periodísticos parece que tampoco leen Página/12". "Hay leyes que no se sabe por qué son secretas, ya que disponen cuestiones como la de comprar vajilla para la residencia de Olivos. Nada misterioso, nada que deba ser ocultado", explicó. Explicó también que la senadora rechazó "el pedido del radical SANZ, de derogar los decretos secretos, a lo que dijo: 'Es incumbencia del Ejecutivo"'. Aventuraba también que el trámite en la Cámara de Diputados no sería breve ${ }^{223}$. Y el tiempo le dio la razón.

\section{El debate en la Cámara de Diputados.}

Página 12 titulaba: Diputados dispuestos a debatir leyes secretas y daba cuenta del atraso en el tratamiento de varios proyectos. Destacaba que el oficialismo y la oposición habían acordado avanzar en una agenda común que involucraba a aquéllas ${ }^{224}$. Luego anticipaba la votación en

\footnotetext{
${ }^{222}$ El 16 de junio de 2005.

223 El 16 de junio de 2005.

${ }^{224}$ El 6 de julio de 2006.
} 
la Comisión de Asuntos Constitucionales. Los legisladores del Frente para la Victoria -decía- firmarán un despacho favorable mientras que el radicalismo y el ARI (Argentinos para una República de Iguales) presentarán dictámenes con un contenido propio. A su vez, el interbloque del PRO (Propuesta Republicana) suscribirá el despacho del oficialismo en disidencia parcial ${ }^{225}$.

Tras la votación anunciaba: El final de los secretos en las leyes del Congreso. Los hechos confirmaban la versión que había anticipado. "El kirchnerismo en la Cámara de Diputados convirtió en ley el proyecto que revoca el carácter secreto de las leyes, dispone la publicación de las existentes en un plazo de 60 días y establece la prohibición de volver a legislar normas de esas características, salvo aquellas relacionadas con seguridad nacional, defensa e inteligencia". La oposición -destacó- reclamó sin éxito que la prohibición y la publicidad también alcance a los decretos secretos.

Dio cuenta de los discursos principales. De Juan Manuel URTUBEY dijo que actuó como miembro informante del oficialismo y que "fue escueto y se limitó a repasar los puntos salientes del proyecto". La argumentación política estuvo a cargo de Diana CONTI para "seducir a la oposición a que abandonen sus dictámenes en minoría". Pero admitió que "la propuesta de CONTI no caló en los opositores". Todos remarcaron que la nueva ley también debía abarcar no sólo a las leyes sino a todas las normas y en especial a los decretos secretos. Sobre esto se explayó el radical Alejandro NieVA quien calificó la ley como un "espasmo de transparencia" y Adrián PÉREZ que "también cargó su discurso sobre este punto" al señalar que "está claro, el problema son los decretos secretos, no las leyes". Por último destacó que si bien "toda la oposición votó en contra del proyecto en general" aquella "dio sus votos en el artículo cuarto que derogó las leyes de ARAMBURU y ONGANíA"226.

Clarín informó: Diputados aprobó el proyecto que ordena publicar leyes secretas. Lo hace de manera breve y prescindiendo de los detalles que suministraba Página 12. "La iniciativa, que tenía media sanción del Senado, autoriza la difusión de 146 leyes firmadas entre 1891 y 1983. Las normas ya habían sido declaradas inconstitucionales por la Justicia". Expresó que el proyecto contaba con la aprobación del Senado y que resumía las

\footnotetext{
${ }^{225}$ El 6 de agosto de 2006.

${ }^{226}$ El 17 de agosto de 2006.
} 
iniciativas de seis senadores oficialistas ${ }^{227}$. Establece la derogación de la ley 18.302 y el decreto 5315 , que regulaban la distribución de fondos reservados y la publicación de las leyes secretas sancionadas entre 1891 y $1983^{228}$.

\section{RECAPITULACIÓN}

En el cierre de este capítulo resulta aconsejable efectuar una síntesis con vistas a lo que se dirá en el próximo.

En primer lugar cabe enfatizar que desde el comienzo de su mandato el presidente Néstor C. KIRCHNER se encargó de colocar la transparencia de los asuntos públicos como uno de los objetivos fundamentales. Así fue con el discurso mismo de asunción ante la Asamblea Legislativa, luego concretado con la sanción del decreto que consagró el régimen de acceso a la información pública.

Contemporáneamente el denominado affaire ALsogarAY que ventiló la actuación de dicha funcionaria y el cobro de sobresueldos basados en normas secretas, disparó el debate público y el reclamo de la difusión de dichas disposiciones. La prensa cumplió aquí un papel destacado pues informó detallada e insistentemente sobre la cuestión.

En este marco, el Congreso se hizo cargo y se dispuso a publicar las leyes secretas. El debate parlamentario fue extenso y dispar en cada una de las Cámaras. En el Senado, se votó por unanimidad la publicación de las leyes que habían sido sancionadas con carácter secreto. En la Cámara de Diputados, la discusión fue más intensa. No sólo no existió unanimidad sino que se hizo evidente que la difusión sólo de las leyes consagraba una publicidad sesgada. El oficialismo propició una difusión que la oposición demostró que resultaba mínima. Aquél percibió que una posición más radical sobre los secretos conducía inevitablemente al Poder Ejecutivo y, con ello, a un mayor control sobre su actuación. Por ello confinó la actuación del Congreso al

\footnotetext{
${ }^{227}$ Como se expuso antes, Página 12 le atribuía la iniciativa a la senadora FERNÁNDEZ DE KIRCHNER; en cambio Clarín señala una iniciativa compartida por otros senadores que es lo que las actas del Senado reflejan.

${ }^{228}$ El 17 de agosto de 2006.
} 
secreto legislativo que -como quedo expuesto- es sólo una parte del secreto estatal.

En este punto, examinada la filosofía política clásica y contemporánea sobre la publicidad, el secreto y la mentira; descripto el contenido de las leyes y su contexto histórico y expuestas en este capítulo, en síntesis, las principales voces del debate legislativo, el siguiente abordará desde distintas perspectivas el análisis de los discursos registrados en el recinto del Congreso de la Nación. 


\section{CAPÍTULO V \\ LAS IDEAS DE PUBLICIDAD DE LOS ACTOS DE GOBIERNO EN EL DEBATE PARLAMENTARIO}

\section{EL DISCURSO PARLAMENTARIO}

1. Es posible distinguir el discurso político ${ }^{229}$ en sus manifestaciones más clásicas del discurso parlamentario como un campo híbrido que mantiene algunas de las características de aquél pero, al mismo tiempo, se distancia por el ámbito de producción, por la forma de circulación y por su finalidad específica. Eliseo VERÓN plantea que el discurso político es un tipo específico de discurso social. Este objeto específico, hace intervenir necesariamente a las instituciones políticas, por lo que el concepto de político, en este caso, califica dos instancias diferentes: las instituciones y los discursos. Por eso, subraya que "dado que una teoría de los discursos sociales parte del supuesto de que las unidades de análisis significativas, en lo que hace al discurso, deben estar asociadas a condiciones de producción más o menos estables, parece lógico situarse dentro del marco de contextos institucionales fácilmente identificables $\mathrm{y}$, sobre todo, respecto de los cuales existen desarrollos teóricos abundantes". VERÓN señala que el discurso político implica "enfrentamiento, relación con un enemigo, lucha entre enunciadores", es decir, la creación de un adversario. El discurso político supone tres tipos de destinatarios: el pro-destinatario, compuesto por el colectivo de identificación (los que comparten la idea), el contra-destinatario (inversión de la creencia) y el para-destinatario, indeciso, que permanece por fuera del discurso y al cual va dirigido lo que es del orden de la persuasión. El discurso político tiene -en esta tesis- una función respectiva a cada destinatario. Así, al pro-destinatario le corresponde la función del refuerzo; al contra-destinatario la polémica; finalmente, al para-destinatario, la persuasión. Puede afirmarse, entonces -

229 VERÓn, Eliseo, "La palabra adversativa", en El discurso político. Lenguajes y acontecimientos, Buenos Aires, Hachette, 1987, p. 1 y siguientes. 
como lo hacen otros autores- que constituye en este sentido un subgénero de discurso político ${ }^{230}$ caracterizado por su complejidad ${ }^{231}$.

Una serie de interrogantes y respuestas articulados facilita

su descripción:

El discurso parlamentario: "1) ¿qué es?; 2) ¿qué tipo de oposición plantea?; 3) ¿qué modelo de resolución de las diferencias plantea?; 4) ¿qué temas plantea?; 5) ¿qué tipo de relación establece entre los participantes?; 6) ¿cómo son los turnos?; 7) ¿qué función del lenguaje predomina?; 8) ¿cuáles son las metas u objetivos?; 9) ¿cómo se pone en juego ganar o perder?; 10) ¿cuáles son las reglas?; 11) ¿cómo es la estructura?; 12) ¿cuál es su relación con la verdad?, y 13) ¿cómo se concluye? Y responden de este modo: 1) es un género altamente formalizado y depende de regulaciones institucionales; 2) la oposición es básicamente ideológica o axiológica; 3) es un modelo competitivo; 4) los temas forman parte de una agenda sujeta a restricciones institucionales; 5) el debate afianza el punto de vista propio de cada participante; 6) la palabra es asignada por el conductor del debate; 7) combina diferentes funciones del lenguaje para encontrar las fallas y derrotar los argumentos del oponente; 8) la meta es el triunfo de la propia posición; 9) cada uno busca ganar; 10) está regido por reglas institucionales; 11) la estructura altamente organizada y sigue formas, pautas y roles estipulados; 12) cada uno defiende sus puntos de vista como la verdad y 13) tiene una conclusión y las divergencias son disueltas" ${ }^{232}$.

El discurso parlamentario consiste en discursos, intervenciones de distinta índole tales como preguntas, respuestas, etc. y diálogos entre los miembros de un parlamento. Pueden apreciarse - como se ha observado ${ }^{233}$ - tres aspectos: a) el espacial (el entorno físico propiamente dicho y al posicionamiento de sus participantes); b) el interactivo (el sistema de turnos, el seguimiento de las intervenciones, las formas de tratamiento, etc.) y c) el de participación de los legisladores. ILIE denomina a estos tres marcos institucional frames.

\footnotetext{
${ }^{230}$ MARAFIOTI, Roberto, "Discurso parlamentario: entre la política y la argumentación", en MARAFIOTI, R. (Editor), Parlamentos. Teoría de la argumentación y debate parlamentario, Buenos Aires, Biblos, 2007, p. 99.

${ }^{231}$ BITONTE María Elena y DUMM, Zelma, "El discurso parlamentario: ¿diálogo en la torre de Babel?", en MARAFIOTI, R. (Editor), Parlamentos. Teoría de la argumentación y debate parlamentario, cit., p. 173.

${ }_{232}$ Ibidem, p. 173.

${ }^{233}$ ILIE, Cornelia, "Parliamentary Discourses", en BROWN, Keith (ed.) Encyclopedia of Language and Linguistics, 2da.edición, Oxford, Elsevier, 2006, volumen 9, p. 188-197.
} 
Pese a las dificultades por su caracterización, la autora señala que los aspectos importantes del discurso parlamentario son: a) la preferencia por la confrontación de ideas y opiniones entre legisladores de distinta ideología y la cooperación entre aquellos otros de un mismo partido y b) la presencia de una audiencia múltiple. Todo esto provoca que los legisladores utilicen un lenguaje altamente estratégico con el fin de alcanzar sus fines políticos. Y concluye: "Las tácticas de los debates parlamentarios consisten en una interacción cooperativa y unos encuentros enfrentados, ambos muestran una lucha por la influencia política y la autoridad que se transmiten parte racional y parte emocionalmente" 234 .

Pero, desde otra perspectiva, también se ha observado que lo realmente distintivo del discurso parlamentario no es el estilo argumentativo ni las características de la interacción ni el lenguaje. Todas estas propiedades también se pueden encontrar en otros géneros. Tampoco el contenido de las intervenciones puesto que éstos también suelen ser temas de actualidad política tratados en diarios, revistas o incluso en conversaciones cotidianas. Ninguna de estas características son exclusivas del discurso parlamentario, lo que es realmente típico del discurso parlamentario es la combinación de todas ellas ${ }^{235}$.

2. El discurso parlamentario tiene, a su vez, subgéneros. Además de la discusión propiamente dicha del proyecto de ley en el recinto, se registran una variedad de subgéneros que involucra: proyectos (de resolución o de declaración), mociones, cuestión de privilegio, discusión, despacho a comisión, homenaje, etc. ${ }^{236}$. Las comisiones funcionan como los ámbitos previos en los que se confrontan las posiciones entre los distintos legisladores. Allí, como en el recinto, existen jerarquías, la del presidente, la de los secretarios y las de los miembros numerarios. Estos espacios son los que posibilitan que se habilite un tema para que llegue al recinto y aquí también hay pautas. No puede hablar cualquier miembro de la comisión sin la autorización

\footnotetext{
234 Ibidem.

235 VAN DIJK, Teun A., "La contextualización del discurso parlamentario: Aznar, Iraq y la pragmática del mentir" en CORTÉs RODRÍGUEZ, Luis María (coordinador), Discurso y oralidad: homenaje al profesor José Jesús de Bustos Tovar, Madrid, Arco Libros, 2007, volumen 1, p. 137. La traducción del artículo corresponde a Jesús G. MARTínEZ DEL CASTILLO.

${ }^{236}$ BITONTE María Elena y DUMM, Zelma, "El discurso parlamentario: ¿diálogo en la torre de Babel?", cit., p. 175.
} 
del presidente. Las comisiones también tienen una jerarquía en la medida en que el pase de un trámite parlamentario por una u otra comisión abre la puerta para que, en el recinto, tenga un tratamiento favorable o desfavorable ${ }^{237}$.

3. Al igual que otros géneros de discurso, los debates parlamentarios tienen muchas estructuras en varios niveles. Por tanto, es posible examinar las propiedades del discurso desde distintas perspectivas ${ }^{238}$ : la entonación, el orden de las palabras, los sentidos de las oraciones, las presuposiciones, la coherencia, el estilo del léxico, etc. ${ }^{239}$. Pero, a fin de no perdernos en esa jungla de estructuras y estrategias discursivas, nos detendremos básicamente ${ }^{240}$ en la argumentación ${ }^{241}$ que los legisladores expusieron para apoyar u objetar la ley propuesta y, con ello, identificar y analizar las ideas sobre la publicidad de los actos de gobierno sostenidas por los legisladores en el marco del debate parlamentario. En este sentido, cabe insistir en que los legisladores defienden y atacan las opiniones y posiciones políticas, argumentan a favor o en contra de los criterios mayoritarios 0 minoritarios y por lo tanto la argumentación debe ser un objeto prominente de análisis en el estudio de los debates parlamentarios

\footnotetext{
${ }^{237}$ MARAFIOTI, Roberto, "Discurso parlamentario: entre la política y la argumentación", cit. p. 97.

${ }^{238}$ En efecto semiólogos, juristas, periodistas, politólogos, sociólogos, lingüistas y otros estudiosos, procuran profundizar en el análisis del discurso desde distintas perspectivas. Se trata de una materia transdisciplinar y pluridisciplinar. Con otras palabras: "Buena parte del trabajo más interesante sobre el discurso se ha hecho fuera de la lingüística en disciplinas tales como antropología, sociología, retórica e investigación literaria" (VAN DIJK, Teun A., Texto y contexto. Semántica y pragmática del discurso, trad. J.D. MoYANO, Madrid, Catedra, 1989 p. 45; más contemporáneamente del mismo autor, véase "Text and context of parliamentary debates" en BAYLEY, Paul (Editor), Cross-Cultural Perspectives on Parliamentary Discourse, Amsterdam-Philadelphia, John Benjamins Publishing Company, 2004, p. 339 y siguientes). Subraya este contexto pluridisciplinario el trabajo de PÊCHEUX, Michel "Sur les contextes épistémologiques de l'analyse de discours" en "Mots", № 9 (1984), p. 7 (existe traducción al español de Andrea COHEN para la cátedra Lingüística Interdisciplinaria de la Facultad de Filosofía y Letras de la Universidad de Buenos Aires que también consultamos).

${ }^{239}$ VAN DIJK, Teun A., "On the analysis of parliamentary debates on immigration" en Reisigl M.Wodak, Ruth (Eds.), The semiotics of racism. Approaches to critical discourse analysis, Vienna, Passagen Verlag, 2000, p. 85. La cita corresponde a la p. 86.

${ }^{240}$ Sólo tangencialmente nos referiremos a otros aspectos, como el estilo u otras herramientas del discurso.

${ }^{241}$ VAN DIJK, Teun A., "On the analysis of parliamentary debates on immigration", cit. p. 97. En este orden de ideas señala MARAFIOTI, que por su propio carácter argumentativo, por tener que defender posiciones discutibles, el discurso parlamentario no puede ser ni puramente monológico, ni puramente dialógico. Según este autor, las opciones que manejan los participantes en una cuestión argumentativa son la proposición, la oposición o la duda (esta última entendida como parte de una estrategia también de oposición, aunque no tan abierta). En ocasiones, el orador despliega tanto los argumentos propios, como los contraargumentos que, empleados por el proponente según su propia orientación, sirven para descalificar al adversario ("Discurso parlamentario: entre la política y la argumentación", cit., p. 108 y 109).
} 


\section{LA PUBLICIDAD EN SENTIDO DÉBIL}

1. Una aclaración: fuertes y débiles.

Efectuaremos una imprescindible aclaración preliminar. Bajo la expresión débil designaremos a aquellos discursos de los legisladores en su mayoría pero no en su totalidad, pertenecientes al oficialismo- que abogaron por la publicación sólo de las leyes secretas sancionadas hasta 1983. Por el contrario, con la voz fuerte nos referiremos a aquéllos que se opusieron por considerar insuficiente la difusión de las leyes pues se conservaban en secreto los decretos emitidos por el Poder Ejecutivo.

También recordaremos que en el capítulo anterior han quedado sintetizados los pasajes más relevantes de las intervenciones, razón por la cual prescindiremos aquí de una nueva transcripción salvo en los aspectos que justifiquen su reiteración.

\section{Una voz en la Cámara de Senadores.}

2.1. El discurso más importante en el recinto estuvo en boca de Cristina FERNÁNDEZ de KIRCHNER que presidía la Comisión de Asuntos Constitucionales $^{242}$. Tan contundente fue su exposición que los senadores afiliados a otras fuerzas partidarias se unieron a ella. Los ejemplos más notables son los experimentados senadores TERRAGNO, LOSADA y SANZ que la acompañaron sin mayores argumentaciones.

Un discurso así, que consiguió la unanimidad del cuerpo ${ }^{243}$ difícilmente pueda considerarse como una argumentación débil. No puede pasarse por alto que si las razones expuestas por la senadora gravitaron para obtener el voto favorable de todos los integrantes del Cuerpo su discurso debe

\footnotetext{
${ }^{242}$ Para entonces representaba a la provincia de Santa Cruz. Poco después, en octubre de 2005 sería elegida senadora por la provincia de Buenos Aires.

${ }^{243}$ Véase el capítulo anterior, punto III, "a", 4.
} 
alcanzar la más alta calificación por su eficacia. Las actas taquigráficas revelan que en unas pocas horas bastaron para obtener la media sanción de la ley ${ }^{244}$.

\subsection{El discurso estuvo orientado a censurar el secreto.}

Para ello lo asoció con las dictaduras militares que lo implementaron y con los gobiernos sucesivos que lo mantuvieron y lo disoció de la administración que encabezaba su esposo, el presidente KIRCHNER. Apuntó, en primer lugar hacia los denominados gastos reservados. Estos gastos reservados son hijos de dos leyes ${ }^{245}$ que corresponden a dos momentos irregulares de la vida institucional del país; una dictada por el gobierno autodenominado Revolución Libertadora que derrocó a PERÓN y el otro, por la Revolución Argentina encabezada por el General ONGANíA. Estas leyes -expresó- no sólo deben publicarse para que cese su carácter secreto sino que además, deben derogarse a fin de limitar al Poder Ejecutivo que no podrá, en el futuro, proponer al Congreso la creación de gastos reservados fuera de las áreas específicas de Inteligencia, Defensa y Seguridad.

Empleó su censura al secreto para deslindar responsabilidades. El secreto no apareció "hace dos, tres o cuatro meses". Y añadió: "siempre hubo leyes secretas en nuestro país. En realidad, en la Argentina no sólo hubo leyes secretas sino también presos secretos, cárceles secretas y muchísimas cosas secretas que nadie denunciaba"246.

Por último, hizo cargo de la importancia relativa que reviste la difusión de las muchas y añosas leyes secretas. Fue clara y ligeramente irónica ${ }^{247}$ cuando afirmó que "hay algunas leyes que en realidad nadie sabe por

\footnotetext{
${ }^{244}$ La sesión comenzó a las 16:06:56 y finalizó 18:35:41. Debe reconocerse, no obstante, que el trabajo de las comisiones parlamentarias demanda estudio y discusión previos y, por ese motivo, el debate en el recinto es más breve y menos determinante.

${ }^{245}$ En rigor, mal llamadas leyes. Se trata de los decretos-leyes 5.315/56 y 18.302/69. Bajo esa fórmula se conocen las disposiciones del Poder Ejecutivo de facto ejerciendo facultades legislativas como ya se señaló en el capítulo III.

${ }^{246}$ Señalamos sólo tangencialmente -porque el tema tiene suficiente autonomía para un estudio autónomo y, de hecho, la bibliografía es extensa y creciente- que aquí se advierte la construcción del ethos de la entonces senadora y luego presidenta. La noción de ethos -como más adelante señalamos con sustento en los textos de ARISTÓtelES, PERELMAN y MAINGUENEAU - es una categoría proveniente de la retórica clásica y reelaborada por teorías argumentativas recientes que alude a la imagen que el locutor construye de sí mismo en el discurso argumentativo. Es necesario aclarar que, en tanto categoría proveniente del acervo de la retórica, el ethos no alude a las características verdaderas del orador sino al modo en que éste se representa, se muestra o se inviste de determinados atributos para los fines argumentativos. Aquí la construcción la enfrenta al pasado militar y, en otros pasajes, al pasado neoliberal.

${ }^{247}$ Desde ARISTÓTELES a autores de nuestros días, desde la antigua Retórica a las más modernas escuelas lingüísticas actuales, el fenómeno irónico ha sido objeto de estudio en sus
} 
qué fueron decretadas secretas, por ejemplo, una vinculada con la compra de vajilla para la residencia de Olivos. No sé cuál sería el motivo, tal vez no querían que nadie se entere de que se renovaba la vajilla". Para entonces, ella misma habitaba en la residencia de Olivos.

En síntesis, poco habría que objetar a una propuesta legislativa que difundía las leyes secretas, que prohibía su dictado hacia el futuro y que derogaba un par de leyes secretas que permitían al Poder Ejecutivo un uso discrecional de los fondos reservados.

2.3. En la sesión no hubo críticas ni observaciones. Un único senador -que anticipó su apoyo a la iniciativa- formuló algunas sugerencias. El senador SANZ ${ }^{248}$ solicitó "la incorporación de las expresiones decretos de necesidad y urgencia y decretos delegados". Es decir que no sólo se publicasen las leyes secretas sino que también se incluyesen estos últimos "que si bien son decretos en su forma, tienen alma y espíritu de ley". "Entonces-concluyó- hacia atrás, entiendo que deben correr la misma suerte que las leyes; es decir, no deben tener más carácter secreto y debe ordenarse su publicación".

En el clima en que venía desarrollándose el debate recuérdese que se había unificado el tratamiento de los proyectos de ley presentados por legisladores de distintos partidos, que existía un informe unánime de la Comisión de Asuntos Constitucionales y que el senador que requería la modificación ya había adelantado su voto en apoyo de la iniciativapodía suponerse una rápida aceptación de parte de la senadora KIRCHNER. Si las leyes secretas debían ser publicadas, los decretos de necesidad y urgencia y los decretos delegados -ambos con sustancia legislativa- debían seguir el mismo camino. El pedido suponía un criterio más amplio con relación al

múltiples variantes: la ironía del sino, la ironía verbal y la ironía dramática. Generalmente, se define la ironía en términos similares a los siguientes: fenómeno que consiste en decir lo contrario de lo que la expresión dice literalmente. DUCROT sostiene que, así considerada, la ironía es una figura que modifica un sentido literal primitivo para obtener un sentido derivado. Es decir, el enunciado evoca literalmente una enunciación en la que este se habría dicho en serio, pero la intención irónica manifiesta en él una creencia acerca del mismo e intenta separarse de su contenido, o porque es claramente falso, o claramente irrelevante. Véase ALCAIDE-LARA, Esperanza R., "La ironía, recurso argumentativo en el discurso político" en "Revista de filología hispánica", volumen 20, № 2 (2004), p. 169. La cita en las p. 169 y 170.

${ }^{248}$ En representación de la provincia de Mendoza a través de la Unión Cívica Radical. Elegido por el período 2003-2009 fue reelegido, completando un segundo mandato el 10 de diciembre de 2015. 
principio de publicidad de los actos de gobierno. Así las cosas parecía difícil resistir la sugerencia.

2.4. Pero así fue. La senadora KIRCHNER en su respuesta desarrolló una argumentación jurídicamente equivocada pero políticamente acertada si se la juzga a la luz de la aceptación unánime que obtuvo. Dijo: "claramente establecimos que nuestras facultades se extienden al tema de las leyes" y que "en todo caso, la publicidad de los decretos reservados y secretos que existan en el ámbito del Poder Ejecutivo es una decisión de ese poder".

El punto débil de las afirmaciones finca en que la publicidad de los actos de gobierno no constituye una suerte de concesión o beneficio que cada uno de los poderes del Estado puede discrecionalmente otorgar o no. La publicidad es un mandato que deriva de la Constitución, de la forma republicana de gobierno que ella consagra y el Congreso cuenta con facultades para reglar la publicidad del secreto aunque derive de una actuación del Poder Ejecutivo. De modo más terminante: negar la competencia del Congreso para regular la materia es renunciar a hacer efectivo el mandato de la publicidad sobre el sujeto estatal que históricamente es el mayor productor de secretos.

El senador SANZ no efectuó ninguna réplica y la senadora que antes había apelado a la ironía- echó mano al sentido del humor en la parte final de su discurso ${ }^{249}$, que fue festejado por oficialistas y opositores. La unanimidad en el resultado de la votación revela que se compartía la idea de abandonar el secreto y de avanzar hacia la publicidad. Pero -como hará evidente el debate en la Cámara de Diputados que examinaremos seguidamente- se soslayaron cuestiones muy relevantes.

2.5. En síntesis, el oficialismo y la oposición dieron media sanción a un proyecto de ley que ordenaba publicar leyes secretas con

\footnotetext{
${ }^{249}$ La senadora confundió el apellido del senador y lo llamó SÁEZ. Cuando fue corregida justificó su error. Dijo entonces: "Perdón, senador SANZ. Había un senador SÁEZ, de la Unión Cívica Radical, y por eso me confundo. Además, era muy buena gente. No se ofenda". El senador LOSADA terció: "Esa es la diferencia. (Risas)". Y concluyó aquélla: "Desde luego que también es buena gente el señor senador SANZ". El empleo del humor en la argumentación tiene una larga tradición. ARISTÓTELES, recordando a GORGIAS, decía que en los debates había que "echar a perder la seriedad de los adversarios por medio de la risa y su risa por medio de la seriedad" (Retórica, trad. de Quintín RACIONERO, Madrid, Gredos, 2000, p. 458 [ Libro III, 18, 1419 b3]). Los estudios contemporáneos no pierden de vista esta antigua herramienta del discurso. Véase TSAKONA, Villy- Popa, Diana Elena, "Humour in politics and the politics of humour. An introduction" en TSAKONA, Villy- Popa, Diana Elena (Editores), Studies in Political Humour. In between political critique and public entertainment, Amsterdam-Philadelphia, John Benjamins Publishing Company, 2011, p. 1 y siguientes.
} 
contenido histórico; derogaba dos de ellas que habían habilitado en el pasado el pago de sobresueldos a funcionarios públicos y prohibía la futura sanción de leyes secretas. De este modo, consagraba un principio de publicidad menguado pues sólo se hacía cargo de la actividad secretas de uno de los poderes del Estado, manteniendo para el Poder Ejecutivo y el Poder Judicial el ejercicio de esa facultad.

\section{Una voz en la Cámara de Diputados.}

3.1. La contribución más importante a la publicidad en sentido débil estuvo en boca de la diputada Diana CONTI ${ }^{250}$. Compartió la fundamentación del dictamen de la mayoría con el diputado URTUBEY pero éste limitó su intervención a unos pocos aspectos generales. Luego le cedió la palabra a su compañera de banca.

"Mi intervención podrá parecer rara -alertó- pero quiero llamar la atención de todos los bloques de esta Honorable Cámara que presentaron dictámenes de minoría a fin de que tratemos en lo posible de lograr unanimidad respecto de lo que a $\mathrm{mi}$ juicio constituye un avance institucional, que si bien no será todo lo que se pueda hacer en la materia, sin dudas es un paso gigante" y "por ello apelo a la coherencia ideológica de todos los bloques de este cuerpo".

Una consideración previa contribuirá al mejor análisis del discurso. En efecto, la diputada CONTI había cesado en su mandato como senadora pocos meses antes. Como tal y junto a la senadora Vilma IBARRA había solicitado un pedido de información al Poder Ejecutivo a fin de que éste hiciese saber a "esta Honorable Cámara de Senadores de la Nación la nómina de normativa secreta o reservada que registra. Asimismo, si los decretos que en anexo se detallan: 1. Son secretos o reservados. 2. En caso afirmativo: a. Si se hayan clasificados. b. Si continúa la necesidad de reserva o secreto"251.

\footnotetext{
${ }^{250}$ Diputada por la provincia de Buenos Aires por el "Frente para la Victoria". Antes -entre el 2002 y 2005- fue senadora por la provincia de Buenos Aires pues reemplazó al ex presidente y, entonces senador, Raúl ALFONSín que había renunciado a su banca.

${ }^{251}$ El pedido fue presentado el 26 de mayo de 2005 y el trámite interno en la Cámara lleva el número 1548/04. Allí afirmaba que "la buena práctica instalada por este gobierno ... permite avizorar entonces, la filosofía de la transparencia, la excepcionalidad del sigilo y, aún en su caso, la no elusión del sometimiento al control parlamentario. Por fin también, la predisposición
} 
Puede, entonces, comprenderse el exordio ${ }^{252}$ con un pedido expreso de unidad parlamentaria y una apelación a la coherencia ideológica. La diputada no podía descartar que la amplitud de criterio que había sostenido en el Senado -reclamando que el Presidente de la Nación informase detalladamente sobre los decretos secretos- podía serle exigida ahora a ella. Es que "el exordio y la presentación son superfluos si la simpatía de que el orador goza hacen inútiles estas precauciones" 253 .

La eficacia de la argumentación y el hecho de que ejerza una influencia más o menos importante sobre el auditorio, dependen no sólo del efecto de argumentos aislados, sino también del conjunto del discurso, de la interacción entre argumentos y argumentos que vienen espontáneamente a la mente del que escucha el discurso. "El efecto de este último se encuentra muy condicionado por la idea que el auditorio se forma del orador. El ethos ${ }^{254}$ del orador, como señala ARISTÓTELES ${ }^{255}$, juega un papel innegable en la manera como el discurso se recibe".

3.2. Tras ello, la diputada reconoció una doble limitación del proyecto de ley. La primera, en sus propias palabras, quedó enunciada así: "si bien no será todo lo que se pueda hacer en la materia, sin dudas es un paso gigante". La segunda tiene que ver con la extensión de ese paso: "el hecho de que estemos derogando el carácter secreto de más de 120 leyes -muchas de ellas de índole puramente histórica- es un avance institucional, aunque no sé si

a hacer público todo cuanto del pasado no amerita secreto y clasificación en los casos que la reserva mantenga vigencia". Énfasis añadido.

${ }^{252}$ Es el comienzo del discurso. Clásicamente se considera la parte cuya principal finalidad es sintonizar con el oyente. En ella hay que impresionarlo con un triple objetivo: ganar su simpatía, llamar su atención y predisponerlo para la escucha o, eventualmente, la lectura o visión. Véase Perelman, Ch.-Olbrechts-TyteCA, L., The New Rhethoric. A treatise on Argumentation, trad. John WILKINSON-Purcell WeAVER, Notre Dame, University of Notre Dame, 2000, p. 17 y siguientes $(\& 3,4$ y 5$)$ y 496 y siguientes.

${ }^{253}$ PeRelmAN, Ch., La lógica jurídica y la nueva retórica, trad. Luis DieZ-PICAZO, Madrid, Civitas, 1988 , p. 175.

${ }^{254}$ El pensador griego fue el primero en otorgarle al êthos un lugar central en el discurso persuasivo, en cuanto lo incluye, junto al logos y al pathos, como un tipo de prueba técnica, obtenida mediante el discurso del orador. En efecto, ARISTÓTELES afirma que se persuade por medio del êthos cuando se pronuncia el discurso de tal manera "que hace al orador digno de crédito" porque "a las personas buenas les creemos más y con mayor rapidez en todas las cosas" pero principalmente en aquellas en los que no hay evidencia sino una opinión dudosa. Concluye así: no es cierto que "la honradez del que habla no incorpore nada en orden a lo convincente, sino que, por así decirlo, casi es el talante personal quien constituye el más firme medio de persuasión" (Retórica, cit., p. 42). Énfasis añadido. Véase también MAINGUENEAU, Dominique, "Problemas de ethos" en "Pratiques" No 113/114 (junio de 2002), pp. 55-67 (traducción de M. Eugenia CONTURSI).

${ }^{255}$ Retórica, cit., p. 41 y siguientes (Libro I, 2, 1356a). 
muy significativo, puesto que hoy en día a nadie se le ocurriría en la Argentina sancionar leyes secretas".

Esta confesión constituyó un esfuerzo en pos de la unanimidad tal como había sido alcanzada en el Senado. La diputada CONTI era una actora enormemente calificada no sólo por su condición de abogada sino porque ella misma cuando integraba aquél cuerpo había impulsado -como se expuso- un pedido de informes al Poder Ejecutivo. Pero para que se advierta la magnitud del secreto bastará con reproducir las palabras de la diputada entonces senadora: "Existirían 5262 decretos secretos correspondientes al período 1976-1983 y alrededor de 200 decretos secretos desde el 10 de diciembre de 1983 a la actualidad. Con respecto a estos últimos, aproximadamente 85 de la presidencia del Dr. Raúl AlFonsín, 108 de la Presidencia del Dr. Carlos Menem, más de dos de la presidencia del Dr. Fernando DE LA RÚA y uno de este gobierno". Esto es existían 5458 decretos, aproximadamente $^{256}$, que podían ver la luz además de las leyes también secretas. Con el proyecto cuya defensa realizaba, ahora prefería que siguieran ocultos.

Pero las transformaciones -podría argüirse en su auxiliorequieren tiempos; no es posible de la noche a la mañana pasar del secreto a la publicidad absoluta. Un primer paso consiste en publicar las leyes que fueron sancionadas en sigilo: "es recién con este gobierno que se empieza el control parlamentario a este tipo de normativa". No tardarán en llegar otras iniciativas que ampliarán el modelo de transparencia que se inaugura.

Esta posición puede encuadrarse en la tipología de los sofismas políticos que expusiera Jeremy BENTHAM ${ }^{257}$. Uno de ellos que denomina sofisma de la marcha gradual: todo se cumple por grados en la naturaleza. Todo debe marchar por grados en la política. La marcha gradual es acompañada por todos los mejores calificativos: es templada, es pacífica, es conciliadora. La marcha opuesta es temeraria, es alarmante. Y continúa: afirmar que las operaciones deben seguirse gradualmente, es decir que deben

\footnotetext{
${ }^{256}$ Surge del pedido presentado el 26 de mayo de 2005 (expediente número 1548/04 de la $\mathrm{H}$. Cámara de Senadores), ya citado, en el que admite que la cifra puede variar.

${ }^{257}$ Tratado de los sofismas políticos, trad. Francisco Ayala, Buenos Aires, Leviatán, 1986. Consultamos también un trabajo mayor que contiene la traducción española y otros escritos, The book of fallacies: from Unfinished Papers from Jeremy Bentham, London, John and H.L. Hunt, 1824.
} 
seguirse en un orden tal que se apoyen y faciliten recíprocamente: es decir que debe comenzarse un edificio por la base y no por el tejado. La magia está sentencia BENTHAM- en la palabra gradual ${ }^{258}$.

Sólo con la interpelación que le dirigieron los discursos de los restantes legisladores ${ }^{259}$ se hará evidente que había un núcleo de secreto que quería ser mantenido en bloque. Para ser más precisos, en ese abrumador número de decretos que la diputada CONTI había identificado podían existir reservas justificadas y otras que no lo fueran. Pero su negativa espejaba en la Cámara de Diputados aquella que había defendido la senadora FERNÁNDEZ de KIRCHNER: el Congreso no iba a intervenir en la vida secreta del Poder Ejecutivo.

3.3. La segunda limitación reconocida por la diputada fue que el paso gigante probablemente no lo fuera tanto. Lo que se iban a publicar eran leyes "muchas de ellas de índole puramente histórica" y con ello un “avance institucional ... no sé si muy significativo".

Como antes se expuso, las leyes secretas sumaban 146 que comprendían más de un siglo -la primera fue dictada en 1891-y los temas más diversos -desde compras de armas hasta obsequios entre presidentes. Fueron sancionadas tanto por gobiernos democráticos como militares, aunque en proporción muy diversa. Los primeros fueron los responsables de sólo un $20 \%$ aproximadamente, mientras que el $80 \%$ restante se gestó en los regímenes militares. Con otro giro, aquéllos dictaron 28 leyes en tanto que los últimos alcanzaron 118.

Efectivamente como la diputada conocía, muchas eran para emplear sus palabras- de índole histórica. La difusión a comienzos del siglo XXI -por ejemplo- de la autorización al Poder Ejecutivo para comprar o vender material bélico en 1894 no puede considerarse una contribución seria a la transparencia. Lo mismo puede afirmarse de la publicación de la ley por la cual -en 1951- se incrementa una partida del presupuesto para realizar construcciones militares o de aquella por la cual el presidente de facto LANUSSE le obsequiaba -en 1972- un equino pura sangre a su colega paraguayo

\footnotetext{
${ }^{258}$ La cita en la p. 85 de la primera obra y p. 203 de la segunda. El autor refiere el caso de un proyecto que suprime las tasas para acceder a los tribunales. Los pobres no pueden afrontarlas. Se acuerda con ello pero se pronuncia la palabra gradual: "De esta manera en un siglo o dos, la justicia será por fin accesible a todo el mundo".

${ }^{259}$ Que examinaremos en el próximo epígrafe.
} 
STROESSNER. Estos ejemplos confirman las modestas expectativas de la legisladora respecto de la relativa trascendencia -intrascendencia, lisa y llana en muchos casos- de la ley que se discutía.

\section{LA PUBLICIDAD EN SENTIDO FUERTE}

Las objeciones a la posición descripta que calificamos como publicidad en sentido débil nacieron de tres bloques partidarios diferentes. La Unión Cívica Radical, a través del diputado Alejandro NiEVA; la Alianza A.R.I., mediante el diputado José Adrián PÉREZ y el partido Propuesta Republicana (PRO), con el diputado Pablo TONELLI formularon discursos críticos que conforman la que denominamos publicidad en sentido fuerte.

a) Los argumentos del diputado NIEVA.

La decisión de publicar las denominadas leyes secretas "es absolutamente insuficiente". Es que -destacó- "en el análisis de la legislación comparada y de la de nuestro país, advertimos que prácticamente la totalidad de las normas secretas emanan de los despachos del Poder Ejecutivo y no del Congreso".

Este argumento, que se reiterará en los otros discursos opositores, no tuvo respuesta. La auténtica usina del secreto estatal se encuentra en los despachos del Poder Ejecutivo. El reconocimiento de los miles de decretos que tienen esa condición -según manifestó la diputada CONTI cuando actuaba como senadora- dan cuenta de esa realidad. Y esa caja secreta permanecerá cerrada cuando se sancione el proyecto de ley oficialista.

Pero el diputado NiEVA asume las consecuencias que tendría la difusión inmediata de todas las disposiciones secretas. Se hace cargo, en algún sentido, del sofisma gradualista benthamtiano. "No estamos diciendo que inmediatamente debemos descorrer el velo para que todo sea transparente" sin embargo "existen decretos secretos que sí deberían conocerse, de la misma manera que el criterio utilizado por el funcionario para emitirlos". Dicho de otro modo, si la oposición levanta la bandera de la publicidad de los actos de gobierno esa publicidad si bien no exige la inmediata 
e íntegra difusión de toda clase de disposición secreta -leyes, decretos, resoluciones, etc.- sí exige, a menos, una evaluación de los motivos que condujeron a limitar su difusión y a establecer si aquéllos subsisten. Y sólo en caso de que hayan cesado, disponer su publicidad.

El discurso denuncia la defensa del proyecto en nombre de la publicidad de los actos de gobierno cuando la legisladora y el bloque al que pertenece conocen que cuantitativa y cualitativamente el secreto que necesita ser reglado es el que se gesta en el ámbito del Poder Ejecutivo. Se trata entonces de una actuación engañosa, de la producción de aquellas leyes conocidas como leyes espectáculo. Se refiere a un constitucionalista español que el legislador no identifica por su nombre. Probablemente se trate de Tomás RAMÓN-FERNÁNDEZ que en un estudio habla "de leyes desechables, de usar y tirar (lois jetables), de neutrones legislativos, porque con frecuencia muchos de los preceptos de este nuevo tipo de leyes carecen de carga jurídica, de textos d'affichage, de droit mou o flou, de derecho en estado gaseoso, de la ley como instrumento de la política-espectáculo". Más adelante describe la censurable gesticulación legislativa que no se corresponde con la competencia que el Congreso o el Parlamento deben ejercer ${ }^{260}$.

El discurso, no obstante, acuerda ${ }^{261}$ con la propuesta de difundir y derogar las leyes secretas que permitieron el pago de sobresueldos durante la presidencia de MENEM. Pero a partir de allí vuelve a argumentar contra la negativa a difundir otras disposiciones secretas que también cobijaron actos de corrupción. En concreto se refirió a los decretos secretos que

\footnotetext{
${ }^{260}$ Véase "De la banalidad a la incoherencia y la arbitrariedad. Una crónica sobre el proceso, al parecer imparable, de degradación de la ley" en "El Cronista del Estado Social y Democrático de Derecho" $N^{\circ} 0$ (2008), p. 46. Aunque supera el propósito de esta nota al pie, destacamos que no encontramos cuestionable que, en ocasiones, los cuerpos legislativos manifiesten su opinión o gesticulen -para retomar las palabras del autor- a fin de hacer conocer su posición en temas relevantes.

${ }^{261}$ La crítica del legislador está orientada y fundada hacia ciertos aspectos del proyecto en discusión. Ejerce una oposición racional y selectiva. Renuncia a implementar lo que se denomina obstruccionismo parlamentario. Véase GONZÁLEZ DE ZÁRATE LORENTE, Roberto, "EI obstruccionismo parlamentario" en "Asamblea: revista parlamentaria de la Asamblea de Madrid" $\mathrm{N}^{\circ} 27$ (2012), p. 183 y siguientes, que observa que se configura "cuando los procedimientos e instituciones parlamentarias: deliberaciones, quórum, votaciones, etc., son instrumentalizados, principalmente por las minorías parlamentarias, con el propósito de entorpecer, alargar 0 impedir la aprobación de leyes". La cita en la p. 184 y los estudios que refiere en las notas 1 y 12.
} 
permitieron la venta de armas a Ecuador y a Croacia que, como luego se supo, constituyeron delitos ${ }^{262}$.

La publicidad que consagrará el proyecto es una publicidad fragmentada, parcial, insuficiente.

b) Los argumentos del diputado PÉREZ.

Si el diputado NiEVA calificó de insuficiente al proyecto de ley, el diputado PÉREZ lo considera un maquillaje. Es más -dijo- "es intrascendente la publicación de las leyes secretas" que sólo nos van a permitir saber que el gobierno ha efectuado "donaciones de caballos de pura sangre" o "importaciones de vajilla de porcelana para la quinta presidencial de Olivos" sin pagar impuestos. Si el proyecto excluye la difusión de los decretos secretos no "develaremos a la sociedad cómo se manejaron en la Argentina los fondos reservados". Más adelante dijo que "resulta irrisorio" que "hoy nos presenten todo esto como un avance y un salto cualitativo en pos de la calidad institucional; esto es pura falacia, cinismo e hipocresía".

Sin renunciar a dar las razones por las cuales exigía que la publicación también se extendiese a los decretos secretos ${ }^{263}$, el discurso tiene un eje emocional que se agrega al contenido de la exposición de aspectos más técnicos ${ }^{264}$. La incorporación de vocablos como maquillaje, hipocresía, cinismo, falacia, etc. así lo indican. También se inclina por la agresión tanto hacia la diputada CONTI como hacia la senadora FERNÁNDEZ de KIRCHNER aunque sin mencionarlas- cuando las trata de mentirosas porque sostuvieron "que podemos llegar a invadir funciones propias del Poder Ejecutivo". Por cierto, no se trata de una mentira sino de una interpretación sobre el rol del Congreso y de la competencia de éste para reglar sobre el carácter público o secreto de los decretos que dicta el Presidente ${ }^{265}$. O más breve aún, se trata de la extensión que quiere darse al principio de publicidad.

\footnotetext{
${ }^{262}$ Bastará con señalar aquí que el presidente MENEM y algunos de los ministros firmantes de los decretos fueron condenados a prisión, aunque al momento de redacción de este trabajo la sentencia de halla recurrida ante la Corte Suprema de Justicia de la Nación.

${ }_{263}$ Que sustancialmente coinciden con las que empleó el diputado NIEVA.

${ }^{264}$ MARAFIOTI, Roberto, "Discurso parlamentario: entre la política y la argumentación", cit., al analizar las razones y pasiones en el discurso argumentativo, en p. 118 y 123.

${ }^{265}$ El diputado NIEVA había sostenido la misma tesis de manera más cortés. De nuestra parte también consideramos que no hay invasión alguna en la vida del Poder Ejecutivo si se reglase la publicidad de los decretos.
} 
La descalificación se profundiza a medida que avanza el discurso y toma un dirección más personal que en el del anterior legislador. "Tengo que confiar en la palabra de la miembro informante de la mayoría que sostiene que este gobierno sólo dictó un decreto secreto" ${ }^{266}$ o "responderé a la convocatoria que ha realizado la señora miembro informante del oficialismo referida a que busquemos un mayor grado de consenso- con otra: que revean el texto que hoy el oficialismo somete a consideración" o "Les cuento. Hubo un incremento de fondos reservados para la SIDE de cien millones de pesos mediante dos decretos, uno de DUHALDE y otro de KIRCHNER, que tenían como destino financiar la campaña de KIRCHNER".

La descortesía o el insulto en el discurso parlamentario no constituyen un instrumento novedoso ${ }^{267}$. Las estrategias de descortesía varían $^{268}$. El diputado PÉREZ emplea varias de ellas en un debate político cara a cara que supone la ubicación de los legisladores en el mismo recinto y a corta distancia: sus interlocutores son mentirosos ${ }^{269}$, contradictorios, ocultadores, hipócritas, cínicos, etc. El discurso político lejos de perseguir armonía o un acercamiento siquiera parcial, pretende resaltar las diferencias y el conflicto. "Por eso cuando dicen que estamos dando un salto están mintiendo. Nuestra propuesta consiste en discutir en serio y dar a publicidad los decretos, prohibiendo para el futuro los decretos secretos".

La publicidad que consagrará el proyecto es una publicidad fragmentada, parcial, insuficiente.

\footnotetext{
${ }^{266}$ En un contexto irónico y sembrando dudas sobre la veracidad de sus dichos.

${ }^{267}$ Véase BLAS ARROYO, José Luis, "No diga chorradas: La descortesía en el debate político cara a cara. Una aproximación pragma-variacionista" en "Oralia" $\mathrm{N}^{\circ} 4$ (2001), p. 9 y siguientes e ILIE, Cornelia, "Insulting as (un)parliamentary practice in the British and Swedish parliaments. A rhetorical approach" en BAYLEY, Paul (Editor), Cross-Cultural Perspectives on Parliamentary Discourse, cit., p. 45.

${ }^{268}$ BLAS ARROYO, identifica cinco grandes estrategias, con sub-estrategias, en el debate cara a cara: 1) asociar al otro con intenciones o hechos negativos (con foco en la incompetencia, la ocultación, la credibilidad, la responsabilidad); 2) decirle que miente; 3) mostrarse despectivo (con foco en el ridículo, en el asombro "no lo creía capaz"); 4) formular contrastes desventajosos (comparación y crítica) y 5) acusar de contradictorio ( en cuanto a acciones y palabras). Su análisis se autodefine como variacionista, toma en cuenta variables de tipo sociolingüístico y describe grados de agresividad verbal. Véase BLAS ARROYO, José Luis, cit. p. 21, punto 3.3 .

${ }^{269}$ Mientras el diputado NIEVA habló de leyes espectáculo, acertada o no, empleó una categoría académica -citando incluso indirectamente a expertos en derecho constitucionalpara descalificar el proyecto de ley, el diputado PÉREZ eligió otro camino para el mismo fin: calificar a sus opositores de mentirosos y de recibir dinero en secreto para sus campañas políticas.
} 
c) Los argumentos del diputado TONELLI.

El discurso del diputado TONELLI es -probablemente- el más breve de todos los pronunciados. La lectura de las versiones taquigráficas de otras sesiones revela, a veces, que más que a un debate se asiste a una colección de discursos con un tema común pero ya preparado, sin suficientes reflejos de parte del expositor para evitar reiteraciones ni para hacerse cargo de cuestiones que fueron sobrevinientes. No fue así en el que motiva este trabajo. Aquí el diputado TONELLI pudo reiterar o apoyarse en el dictamen en minoría que suscribió en la Comisión de Asuntos Constitucionales ${ }^{270}$. Pero prefirió mostrar los puntos con los que acordaba y con los que disentía casi de forma esquemática.

"Apreciamos como loable -dijo- el propósito de quitar el carácter secreto que tienen muchas leyes sancionadas por el Congreso". Tal como lo hicieron todos los legisladores sin excepción apoyó la idea de la difusión de las leyes secretas. Pero se apartó de la de prohibir hacia el futuro la sanción de leyes con dicha condición. Explicó que "razones de defensa, de seguridad o de relaciones exteriores" podían, eventualmente, hacer necesario dictar leyes bajo esa condición. Si los decretos pueden ser secretos no se advierten motivos para impedir que un órgano colectivo como el Congreso excepcionalmente acuda a dicho mecanismo ${ }^{271}$.

La publicación de los decretos secretos es un instrumento para perseguir los actos de corrupción. Sobre esa base propició su publicación haciendo un moderado uso de la ironía: "Es curioso que la diputada miembro informante del dictamen de mayoría haya reconocido que, efectivamente, en los decretos del Poder Ejecutivo de carácter secreto o reservado suelen aparecer los gérmenes de los actos de corrupción, y sin embargo en el

\footnotetext{
${ }^{270}$ También está suscripto por el entonces diputado Jorge R. VANOSSI, conocido profesor de derecho constitucional y cuya impronta se advierte de la lectura del texto.

${ }^{271}$ SAGÜÉS, Néstor P., op. cit. El autor señala que "dentro de las rigurosas pautas del estado de necesidad, y siempre destacando su peculiaridad y excepcionalidad, el secreto de las sesiones parlamentarias o de la ley puede encontrar un albergue esporádico y transitorio. Cuando está en juego la suerte de la República, como decía Joaquín V. GonZÁlEZ una norma puede devenir secreta si su ocultamiento fuera entonces indispensable para que el país, como quienes lo integran, subsistan como comunidad independiente" (p. 69). Si bien se muestra partidario de la inconstitucionalidad de las leyes secretas, recuerda que la tesis que la admite circunscribe su ámbito "a la esfera interna del Estado (reglarían, por tanto, relaciones de órganos gubernativos entre sí, de agentes oficiales con reparticiones públicas, etc.)" (p. 107).
} 
proyecto en consideración se niega la posibilidad de quitar a los decretos el carácter secreto".

Una de las características del discurso parlamentario es el sistema de turno para el uso de la palabra ${ }^{272}$. En términos generales puede afirmarse que es distinta la suerte de quien habla en primer o en último lugar pues la ventaja para aquél consiste en que puede agotar los argumentos y privar a los sucesivos oradores de añadir algo nuevo. El diputado TONELLI neutralizó dichas desventajas con un discurso breve que se sirvió de los argumentos que ya se habían enunciado pero ordenándolos, adhiriendo a algunos y separándose de otros.

La publicidad que consagrará el proyecto -consideró- es una publicidad fragmentada y la prohibición cerrada de secreto legislativo es equivocada frente a la amplitud existente en materia de decretos secretos.

\section{LUCES Y SOMBRAS SOBRE LA ACTUACIÓN DE LOS PODERES PÚBLICOS}

1. La palabra publicidad fue empleada cinco veces en el debate en el Senado y treinta en la Cámara de Diputados. Pero a esta altura, podemos afirmar que los legisladores utilizaron la misma palabra o significante pero no el mismo concepto o significado. A lo largo del debate en ambas Cámara la publicidad de los actos de gobierno significó, alternativamente:

a) La obligación del Congreso de publicar las leyes secretas, de prohibir su dictado en el futuro y de reconocer que la publicación de los decretos secretos en un asunto propio del Poder Ejecutivo.

b) La obligación del Congreso de publicar las leyes secretas, de prohibir su dictado en el futuro y de difundir los decretos secretos, luego de examinarse si existen o subsisten motivos suficientes que justifiquen su reserva.

\footnotetext{
${ }^{272}$ El reglamento, en este caso de la Cámara de Diputados (art. 137), dispone que el orden con que se concederá el uso de la palabra: 1 . Al miembro informante de la comisión que haya dictaminado sobre el asunto en discusión. 2. Al miembro informante de la minoría de la comisión, si ésta se encontrase dividida. 3. Al autor del proyecto en discusión. 4. Al diputado que asuma la representación de un bloque. 5. Al que primero la pidiere entre los demás diputados.
} 
c) La obligación del Congreso de publicar las leyes secretas, de prohibir su dictado hacia el futuro y de difundir todos los decretos secretos.

d) La obligación del Congreso de publicar las leyes secretas, de permitir bajo ciertas circunstancias el dictado de leyes con ese carácter en el futuro y de publicar los decretos secretos cuya reserva no esté justificada.

2. En términos esquemáticos la situación es la siguiente:

\begin{tabular}{|l|l|l|l|}
\hline & LEYES SANCIONADAS & \multicolumn{1}{|c|}{ LEYES FUTURAS } & DECRETOS PEN \\
\hline F. de KIRCHNER & Difusión absoluta & Prohibición absoluta & No difusión \\
\hline SANZ & Difusión absoluta & Prohibición absoluta & No difusión \\
\hline CONTI & Difusión absoluta & Prohibición absoluta & No difusión \\
\hline NIEVA & Difusión absoluta & Prohibición absoluta & Difusión relativa \\
\hline PÉREZ & Difusión absoluta & Prohibición relativa & Difusión absoluta \\
\hline TONELLI & Difusión absoluta & Prohibición relativa & Difusión relativa \\
\hline
\end{tabular}

3. En términos gráficos puede presentarse así:

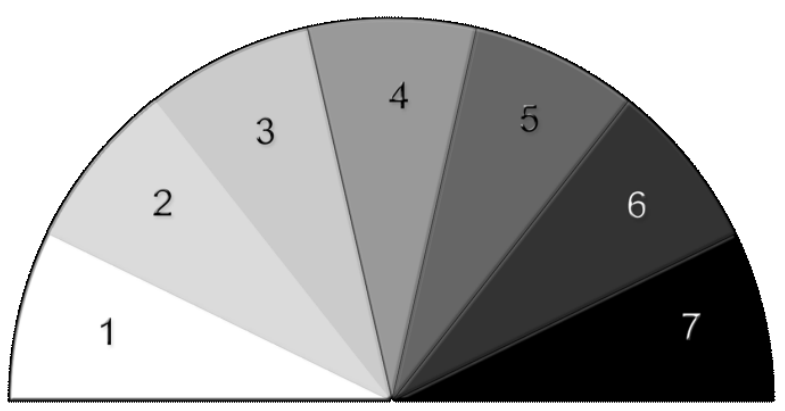

1. Transparencia absoluta

2. Diputado PÉREZ

3. Diputado TONELLI

4. Diputado NIEVA

5. Diputada CONTI

6.Senadora FERNÁNDEZ DE KIRCHNER

7. Secreto absoluto

El extremo izquierdo representa la transparencia absoluta y el extremo derecho el secreto absoluto. Las posiciones de los legisladores en el Congreso pueden leerse siguiendo el orden numérico y representan de modo creciente un criterio menos amplio respecto de la publicidad de los actos de gobierno. 
4. Entre dos extremos -el del secreto absoluto y el de la transparencia absoluta- debe ubicarse el sistema argentino. Ambos desechables porque un secreto monolítico sería incompatible con la forma republicana de gobierno que adopta la Constitución Nacional y una transparencia absoluta tornaría inviable la realización de ciertos cometidos estatales. Por ello, el denominado secreto democrático ${ }^{273}$ tiene un ámbito propio, oscilante según las ideas que prosperen en los momentos de la historia. El debate parlamentario testimonia esas oscilaciones. Libera las leyes que han permanecido ocultas y asume el compromiso de no dictar leyes que revistan esa condición. Pero como la actividad estatal no se ciñe al Poder Legislativo aparecieron las voces que reclamaron por la actuación del Poder Ejecutivo. Aquí surgieron las discrepancias. Se advirtió que la producción diaria y masiva del secreto estatal se gesta en aquél. Por ello algunos postularon la necesidad de su difusión; otros consideraron aconsejable una dosis de opacidad para apreciar un fenómeno del que resultaría una transparencia enceguecedora.

La competencia del Poder Ejecutivo para resolver en secreto permanecía inalterada. Los secretos del pasado tampoco eran difundidos. Cada tanto, cuando una cuestión de relativa importancia toma estado público el Poder Ejecutivo manifiesta que levantará el secreto o abrirá los archivos pero se trata de una gracia o concesión a la que acude ocasionalmente pero no en forma reglada ni periódica. Existe un manejo oportunista que dista de constituir una política de Estado. Fruto de esas decisiones ocasionales se dispuso -por ejemplo- la desclasificación de la información que obrase en manos del Poder Ejecutivo vinculada con el intento de copamiento del "Regimiento de Infantería Mecanizada III General Belgrano" de la localidad de La Tablada, partido de La Matanza, provincia de Buenos Aires ocurrido el 23 de enero de $1989^{274}$ o de la relacionada con el atentado ocurrido el día 18 de julio de 1994 contra la sede de la Asociación Mutual Israelita Argentina en la ciudad de Buenos Aires (A.M.I.A.) ${ }^{275}$.

5. La batalla política que se libró en ambas cámara durante el debate parlamentario puede verse como el intento de mantener el secreto en

\footnotetext{
${ }^{273}$ ThOMPSON, Dennis F., "Democratic Secrecy", cit., p. 130.

${ }^{274}$ Decreto $1578 / 2008$ del $1-10-2008$.

${ }^{275}$ Decreto 395/2015 del 12-3-2015.
} 
manos del Poder Ejecutivo pero levantando la bandera de la publicidad de los actos de gobierno. Los opositores procuraron demostrar que una publicidad fragmentada no sólo resultaba insuficiente sino que, en rigor, nada aportaba a la necesaria transparencia que demanda un Estado de derecho. Fueron derrotados entonces. Pero, años después en 2012, FERNÁNDEZ de KIRCHNER como presidenta de la Nación- emitió un decreto ${ }^{276}$ que convierte en triunfo el discurso de la minoría. Mediante aquél resolvió dejar "sin efecto el carácter secreto o reservado de los decretos y decisiones administrativas dictados por el Poder Ejecutivo con anterioridad a la vigencia de la presente medida", "con excepción de aquellos que, a la fecha, ameriten mantener dicha clasificación de seguridad por razones de defensa nacional, seguridad interior o política exterior y encomendó a los ministerios y secretarías "efectuar el relevamiento de los decretos y decisiones administrativas clasificadas como secreto o reservado, a los fines del cumplimiento de lo dispuesto". El diputado NIEVA -vencido en el debate de entonces- halló un tardío reconocimiento de su posición.

6. El secreto legislativo ha finalizado en la Argentina, al menos parcialmente. Pero ha quedado intacto el secreto del Poder Ejecutivo. Aquél, ya develado mostró sorpresas aunque así algunas curiosidades. Para ser más precisos, abundaban las disposiciones referidas al secreto militar, a la seguridad nacional, a ciertos aspectos de las relaciones internacionales. Esto es, a los supuestos clásicos en los que se impone el sigilo en la actuación estatal. En cambio, la mayoría triunfante en el debate, hizo una defensa del secreto presidencial a punto de considerarlo -como se expresó- un tema fuera de la competencia del Congreso.

Pero tampoco el Congreso fue terminante con su propio secreto. El Reglamento de la Cámara de Diputados establece que "las sesiones serán públicas, pero podrán ser declaradas secretas, previa resolución de la Cámara, aprobada por el voto de la mayoría absoluta". Pero también le da participación al Presidente de la Nación para "sesión secreta para que la Cámara resuelva en ella si el asunto que la motiva debe o no ser tratado reservadamente" e "igual derecho tendrán cinco diputados, dirigiendo

\footnotetext{
${ }^{276}$ Se trata del decreto $2103 / 12$ del 31 de octubre de 2012. Meses después la Cámara de Diputados mediante una declaración expresó "su beneplácito por el dictado del decreto". Una de las firmantes fue la diputada CONTI.
} 
al efecto una petición por escrito al presidente" (arts. 31 y 32). Disposiciones análogas contiene el Reglamento de la Cámara de Senadores (arts. 18 y 19). Estas disposiciones aún vigentes -ambos reglamentos desde la fecha del debate que examinamos fueron reformados en varios aspectos- muestran al menos una vocación parcial por la publicidad.

7. La corrupción de los funcionarios también fue esgrimida como una justificación más de la conveniencia de una amplia publicidad de los actos de gobierno. El presidente KIRCHNER apuntaba sus armas hacia el presidente MENEM, sus políticas neoliberales y sus actos de corrupción ${ }^{277}$. Y en este sentido, el argumento de la corrupción no constituía un ataque hacia el partido gobernante que, para entonces, estaba libre de sospechas en la materia. Como se ha señalado el régimen de apertura gubernamental es un disuasivo para la corrupción y Louis BRANDEIS, lo describió acertadamente: "como se sabe, la luz del sol es el mejor desinfectante"278. Pero este conjunto de razones fue insuficiente para incluir al Poder Ejecutivo en la norma que se gestaba.

A esta altura parece claro que varias fueron las ideas sobre la publicidad de los actos de gobierno que se enarbolaron durante el debate examinado. Las triunfantes suministraron apenas una tenue luz, un amanecer con muchas nubes.

\section{RECAPITULACIÓN.}

\footnotetext{
277 "La década de 1990 representa un hito en los debates y discusiones sobre corrupción política. En esos años, encontramos un crecimiento muy importante de las denuncias de corrupción en diversos países, uno de cuyos rasgos comunes más notables es la incorporación definitiva de los escándalos a la vida política que, en efecto, se multiplicaron desde fines de los años ochenta, con un impacto y un alcance cada vez más considerables. En los años noventa, nuestra región no escapó a este fenómeno. En países como Brasil, Perú o México los escándalos de corrupción tuvieron importantes consecuencias institucionales y en otros como la Argentina dejaron una huella indeleble en las presidencias del período". Véase PEREYRA, Sebastián, Política y transparencia. La corrupción como problema público, cit., p. 17. Un análisis global del tema -que además contiene reiteradas referencias a la Argentina- puede encontrarse en ROSE-ACKERMAN, Susan, La corrupción y los gobiernos. Causas, consecuencias y reforma, trad. de Alfonso COLODRón GómEZ, Buenos Aires, Siglo Veintuno Editores, 2001, ps. $20,49,54$ y 266.

${ }^{278}$ La cita íntegra dice así: "Como se sabe la luz del día es el mejor desinfectante; la luz eléctrica el policía más eficiente". Véase BRANDEIS, Louis D., "What publicity can do" en "Harper's Weekly" (New York) del 20-12-1913. La cita corresponde a la p. 10.
} 
A modo de cierre del capítulo nos interesa destacar una serie de cuestiones que nos permitirán encarar la tarea final de formular las conclusiones de nuestra investigación.

En la historia legislativa, a diferencia de lo que suele ocurrir con frecuencia, el que examinamos constituyó un genuino debate parlamentario. No se trató de una suma de discursos previamente escritos y sólo pronunciados en el recinto. Se discutió, se intercambiaron ideas, se enfrentaron posiciones.

Los discursos parlamentarios aquí estudiados -como especie del discurso político- emplearon todas las herramientas que los teóricos describen: los argumentos de autoridad y ad hominem, la ironía, el humor, el exordio, la cordialidad, la descortesía, etc.. Todas las características y técnicas atribuidas a estos discursos se encuentran compendiadas aquí.

A diferencia de lo que ocurre regularmente en la actividad parlamentaria, en el caso no es posible trazar una división de los operadores acudiendo a la tradicional división entre oficialistas y opositores. Como se expuso, la discusión en el Senado mostró un cuerpo unido en la decisión de abolir el secreto. Las dos fuerzas mayoritarias tradicionales -el Partido Justicialista y la Unión Cívica Radical- votaron en el mismo sentido. Es más, los que estaban por fuera de ellas también se unieron pues la decisión fue unánime.

La Cámara de Diputados mostró otro rostro. La calidad técnica de la discusión se elevó. Los diputados no aceptaron dócilmente que la nueva ley imponía la transparencia venciendo a un pasado de oscuridades y secretos. Aquí se produjo la división tradicional entre oficialismo y fuerzas aliadas y oposición. Como se vio, el número de votos le dio el triunfo al primero pero sus argumentos fueron débiles y cada una de las fuerzas políticas opositoras se lo hizo saber.

La batalla política que se libró en el Congreso puede verse, entonces, como el intento del oficialismo de mantener el secreto en manos del Poder Ejecutivo pero levantando -al tiempo- las banderas de la publicidad de los actos de gobierno. En realidad, el secreto legislativo ha finalizado en la Argentina pero permanece intacta la usina que los produce periódicamente y sin control aparente: el Poder Ejecutivo 


\section{CAPÍTULO VI \\ CONCLUSIONES}

\section{PASADO Y PRESENTE DEL SECRETO DE ESTADO EN LA ARGENTINA}

Estas páginas nos demandaron recorrer la historia de las ideas políticas sobre el secreto de Estado, la mentira política, la publicidad de los actos de gobierno, la transparencia y la corrupción. Nos impusieron también transitar la historia institucional argentina desde la instalación del primer gobierno patrio y las leyes secretas que fueron acompañando a los sucesivos. Nos detuvimos, finalmente, en el período comprendido entre 2005 y 2006 en el que se desarrolló el debate parlamentario. Ahora corresponde exponer -como impone esta instancia académica- un aporte crítico individual al estado de la cuestión de un tema específico.

1. La noticia es oficial: existen leyes secretas.

Los recelos sobre el secreto de Estado en la Argentina tuvieron una inesperada confirmación cuando el Congreso de la Nación asumió la existencia de leyes secretas. Siempre se había admitido que el Poder Ejecutivo pudiese actuar de ese modo, al menos a través de las llamadas agencias de inteligencia. Incluso los más demócratas reconocían -no sin algo de pudor- que se trataba de un mal necesario. Pero que el Congreso que representa al pueblo actuara a sus espaldas no sólo era desconocido por la mayoría de los ciudadanos sino también por un apreciable número de abogados. Es que "para el sentido común, la idea de una ley secreta es simplemente contraintuitiva. Para quienes hemos tenido formación jurídica, se trata de una anomalía de difícil justificación, en el marco de un ordenamiento jurídico positivo" 279 .

En un proceso judicial seguido contra una funcionaria pública federal de alto rango - se trataba, como se dijo en páginas anteriores, de María Julia AlsogarAY- por enriquecimiento ilícito, los medios de comunicación se encargaron de difundir que la defensa reclamaba su

279 CONTRERAS V. Pablo, "Transparencia y leyes secretas en Chile" en "Estudios Constitucionales", Año 8, № 2 (2010), p. 87. 
absolución sobre la base de una ley secreta que autorizaba el pago de una remuneración adicional, equivalente o superior a la que mensualmente percibía por su cargo. Pero no sólo se confirmó la existencia de una ley sino que, probablemente, superaran el centenar. Esto dio origen a una de las discusiones públicas más sensibles desde que el sistema democrático inició su nueva marcha a partir de 1983.

El debate parlamentario que culminó con la sanción de la ley 26.134 ordenó la publicación de las leyes secretas en la Argentina. Pero no eliminó el secreto pese a su retórica. No sólo lo mantuvo sino que lo concentró en el Poder Ejecutivo sin sujetarlo a mayores controles. Y dejó al descubierto las debilidades del sistema democrático que mostraba -y muestra aún- más opacidad que transparencia.

2. El discurso de la transparencia.

La continuidad democrática en el país reiniciada en 1983 tuvo un importante impulso con la reforma constitucional de 1994. La incorporación de tratados y convenciones internacionales al derecho interno y un mayor activismo judicial, tanto a nivel nacional -encabezado por la Corte Suprema de Justicia- como internacional -guiado por la Corte Interamericana de Derechos Humanos- potenciaron el derecho a la información de los ciudadanos, una de cuyas variantes es la información pública. Los reclamos por reglar el acceso a ésta comenzaron a hacerse notar en la agenda política favorecidos por las investigaciones judiciales de hechos de corrupción. Empezó a instalarse el denominado discurso de la transparencia que sustituía -en lo verbal, en principio- al antiguo principio de la publicidad de los actos de gobierno. La Argentina, tardíamente, incorpora en el 2003 una regulación para el orden federal que organiza el sistema de acceso a la información pública. Las provincias siguen análogo recorrido encabezada por la Ciudad Autónoma de Buenos Aires que consagra el que, probablemente, sea el mejor sistema, acompañado por amplios criterios judiciales.

Este clima también se vio favorecido por la presencia de estos problemas en los medios de comunicación. Bastará con señalar las mediciones -difundidas en los diarios de circulación nacional- de LATINOBARÓMETRO que determinaban que la inseguridad, la economía y la 
corrupción constituían los principales problemas de la población en el país ${ }^{280}$. Periódicamente también se difundían -y aún continúan- las encuestas de TRANSPARENCY INTERNATIONAL -autoproclamada como coalición global contra la corrupción- que a través de su índice (corruption perceptions index) colocaba a la Argentina en las peores posiciones de América Latina ${ }^{281}$.

\section{La experiencia de los Estados Unidos de Norteamérica. \\ El modelo estadounidense de acceso a la información} pública a través de la Freedom of Information Act también alcanzaba difusión en Argentina. Por un lado, los estudios académicos principalmente jurídicos que buscaban inspiración en aquella ley y en la larga práctica en los Estados Unidos de Norteamérica para diseñar las normas y prácticas en nuestro país ${ }^{282}$. Pero, por otro, sus bondades eran percibidas por la información que periódicamente se revelaba con su empleo, principalmente en los asuntos vinculados con la dictadura iniciada en 1976. En este sentido, eran notables los logros alcanzados pues por aquella vía era posible obtener información sobre actividades militares y políticas que auxiliaban a reconstruir el pasado en el país ${ }^{283}$. También los procesos penales reiniciados -a impulso de la política en materia de derechos humanos del presidente KIRCHNER- contra los militares se beneficiaron con datos provistos de esta forma ${ }^{284}$. Expresado de otro modo, información difícil o imposible de obtener en el país era alcanzada, mediante aquél mecanismo, en el extranjero.

Pero en los Estados Unidos, tras los atentados sufridos el 11 de septiembre de 2001, se registró un proceso inverso al que se venía

\footnotetext{
${ }^{280}$ Una síntesis que abarca diez años antes y diez años después del período en que se desarrolló el debate parlamentario de la ley que examinamos, puede encontrarse en LATINOBARÓMETRO, Informe 1995 - 2015, Santiago de Chile, p. 69, 71 y 101.

${ }^{281}$ En 2006 sobre un total de 159 países evaluados Argentina estaba ubicada en el puesto 97, Brasil en el 62 y Chile en el 21 (Global Corruption Report 2006, London, Pluto Press, 2006, p. 298). En 2015 -con 168 países examinados- Argentina, en el puesto 107, Brasil en el 76 y Chile en el 23 (Corruption Perceptions Index 2015).

${ }^{282}$ VALLEFÍn, Carlos A., El acceso a la información pública. Una introducción, Buenos Aires, Ad Hoc, 2009, p. 31 y siguientes.

${ }^{283}$ Novaro, Marcos, Cables secretos, Edhasa, Buenos Aires, 2011.

${ }^{284}$ En 2002 aceptando un pedido del gobierno argentino y de la organización Madres de Plaza de Mayo, el Departamento de Estado desclasificó 4677 documentos vinculados a los abusos en materia de derechos humanos en la Argentina entre 1975 y 1984 (Argentina: Declassification of Documents Related to Human Rights Abuses Occurring Between 19751984). Véase Las luchas por la memoria en América Latina. Historia reciente y memoria política. Allier Montaño, Eugenia y CREnZEL, Emilio (Coordinadores), México, UNAM, Instituto de Investigaciones Sociales, 2015, p. 337 y siguientes.
} 
dando $^{285}$. Las políticas de apertura que había impulsado el presidente William CLINTON retrocedieron frente a las impuestas por su sucesor, George BuSH (h). El argumento de la seguridad nacional se expandió para justificar el rechazo de las peticiones de acceso a la información y se incrementó en número de documentos que se consideraban clasificados, fenómeno conocido como overclassification. Por último Barack ОВAMA, procuró limitar dicha práctica y obtuvo que el Congreso sancionara en 2010 la Reducing Over-Classification Act cuyos resultados no son los esperados.

4. El tema del secreto y la mentira atraviesa la historia de la filosofía política.

Bajo el título de transparencia se registra una enorme tarea bibliográfica. En la discusión pública, los candidatos de los partidos políticos, las organizaciones no gubernamentales y la ciudadanía en general, la proponen o la exigen. Nos hemos hecho eco de este aspecto cuando nos referíamos a las promesas incumplidas de la democracia. Pero también hemos querido enfatizar que no se trata de un asunto coyuntural sino de uno de los temas centrales de la reflexión política pues se vincula de manera directa con el corazón del sistema democrático o, con mayor precisión y para emplear las palabras de Elias CANETTI, el secreto ocupa la médula del poder. El pensamiento bobbiano que hemos seguido en varios pasajes del trabajo considera que la democracia es el gobierno del poder visible, es el ejercicio del poder público en público, en donde público es utilizado para oponerlo a secreto. En ella la publicidad es la regla, el secreto es la excepción. En el gobierno popular el poder está más cerca de los ciudadanos y, como se sabe, mientras más cercano es el poder, más visible. La autocracia, en contraste, es el gobierno del poder invisible, es el ejercicio del poder público en privado. En ella el secreto de Estado no es la excepción sino la regla. En el gobierno autocrático el poder está más lejos de los individuos y, como se sabe, mientras más lejano es el poder menos se ve.

$Y$ aunque hemos marginado de este estudio el análisis del secreto desde otras disciplinas -hemos referido no obstante los trabajos

\footnotetext{
${ }^{285}$ UHL, Kristen E. "The Freedom of Information Act Post-9/11: Balancing the Public's Right to Know, Critical Infrastructure Protection, and Homeland Security" en "American University Law Review", vol. 53, № 1 (2003), p. 261.
} 
sociológicos de SIMMEL- no dejamos de advertir que éste está en todos lados y forma parte indispensable de la vida de las personas y de las comunidades. En ciertos lugares, tiempos y desarrollos, el secreto parece cobrar nuevas fuerzas y tratar de ocupar mayores espacios sociales, estatales y personales ${ }^{286}$.

5. El objeto ocultado: el contenido de las leyes secretas.

Cuando los legisladores iniciaron el tratamiento de los proyectos de ley que proponían difundir las leyes que habían sido sancionadas con carácter secreto tomaron conocimiento de la existencia de dichas leyes y, por supuesto, de su contenido. Este último, a nuestro juicio, constituyó un aspecto muy relevante para solución final a la que arribaron.

Señalamos que desde la primera, sancionada en 1891 hasta la última en 1983, este instrumento se usó con dispar intensidad, arrojando un total de 146 en toda la historia institucional del país. Las denominadas leyes secretas fueron sancionadas tanto bajo la vigencia de gobiernos democráticos como regímenes de facto. Vale aquí tener presente que durante éstos el Poder Ejecutivo asumía funciones legislativas frente a la clausura del Congreso de la Nación. Es claro entonces que no podían sancionar leyes en sentido constitucional y que sus leyes no eran propiamente tales pese a lo cual le impusieron dicha denominación como un mecanismo más de legitimación. Fueron, además, los mayores productores de leyes secretas: 118 sobre 146 .

Cuando salieron a la luz por decisión del Congreso en 2006, el conocimiento de ellas en la mayoría de los casos no constituyó ningún aporte significativo para la consolidación de la transparencia. Los hechos ocurridos durante la presidencia de PELlegrinI, SÁEnz PEÑA, RocA o QuintANA, por ejemplo, en razón del carácter más que centenario que revisten. Otros, más contemporáneos, como los acaecidos en los mandatos presidenciales de PERÓn porque la condición de secreta que se les imprimió a las leyes, se inscribe en los marcos tradicionalmente admitidos para tolerar el secreto: las relaciones internacionales y la defensa militar. Por último, la difusión de las leyes dictadas por los gobiernos militares en la década del sesenta y setenta -

\footnotetext{
${ }^{286}$ LABOURDETTE, Sergio, "Secreto y poder en la vida social", en "Orientación y Sociedad", vol. 5, enero/diciembre de 2005 (La Plata), p 59.
} 
que podrían iluminar problemas no resueltos del presente- tampoco es significativa. Se han podido conocer aspectos casi anecdóticos entre dictadores como la referida donación de caballos de LANUSSE a STROESSNER. Es evidente aquí que los secretos de Estado de esta época no se documentaron bajo la forma de leyes.

Por el contrario, la difusión de una ley que autorizaba el pago de gastos reservados, su derogación y la implementación de un nuevo sistema bajo el control de una comisión especial del Congreso limitado a cuestiones de inteligencia inherentes a los organismos comprendidos en las leyes de Inteligencia Nacional, Seguridad Interior y Defensa Nacional es un contundente aporte a la transparencia en ese sector. Aunque, claro está, su éxito o fracaso dependerá del celo que los legisladores coloquen en la función que se atribuyeron.

6. La publicidad en sentido fuerte y en sentido débil.

Como hemos explicado, el debate en cada una de las cámaras del Congreso fue distinto. En el Senado de la Nación el presidente KIRCHNER no contaba con mayoría. Para entonces, Cristina FERNÁNDEZ DE KIRCHNER ocupaba una banca. Tras una exposición clara y convincente el resto de los senadores de todo el arco político decidieron acompañarla. La única cuestión que se planteó -que más que planteo pareció una sugerencia de un senador de la Unión Cívica Radical- se refirió a la publicidad de los decretos. La senadora disipó las dudas y alcanzó la media sanción. El punto era muy relevante y tan sorprendente fue la respuesta de aquélla como la aceptación del cuerpo. Dijo que el Congreso tenía competencia para prohibir el secreto legislativo pero que no podía avanzar sobre los secretos del Poder Ejecutivo. Para ofrecer un punto de referencia de la magnitud del desacierto, diremos que todos los países que han reglamentado los secretos del Poder Ejecutivo -en América Latina y en Europa- lo han hecho, precisamente, mediante leyes.

En la Cámara de Diputados se registró un auténtico debate. En muchas ocasiones la lectura de los diarios de sesiones revela, simplemente, una colección de discursos previamente elaborados. Aquí no. El punto principal que separó a los diputados fue la negativa de algunos -para entonces la mayoría, gestada con alianzas, acompañaba al presidente KIRCHNER en ese 
recinto- a limitar la difusión sólo a las leyes secretas. Dejar al margen toda la actividad del Poder Ejecutivo mantenía prácticamente el statu quo en razón de la relativa importancia que tenían las leyes que se difundirían. Los legisladores que encabezaron esta oposición, uno a uno, mostraron la incongruencia de la acotada propuesta oficialista. Pero ésta, finalmente alcanzó el número necesario para convertir en ley el proyecto votado en el Senado.

Todos los legisladores invocaron la publicidad como requisito indispensable para la existencia de un gobierno republicano. Pero no todos le asignaban la misma intensidad al concepto. De allí que en la descripción que formulamos el capítulo correspondiente, calificamos a una como publicidad en sentido débil y a la otra, en sentido fuerte.

El resultado visible es que se reconoció la existencia de esa extraña figura de una ley secreta y que el propio Congreso decidió difundir toda aquella actividad que había desarrollado bajo esa condición. Pudo avanzar responsablemente para contribuir genuinamente a la publicidad de los actos de gobierno pero, deliberadamente, no lo hizo.

\section{SOBRE EL FUTURO: OPACIDAD O TRANSPARENCIA}

La persecución de los hechos de corrupción ocurridos durante el mandato del presidente MENEM -valga una nueva reiteraciónconstituía una de las políticas que enarbolaba el presidente KIRCHNER. Difundir la ley secreta que autorizaba el pago de gastos reservados y modificarla bajo el control del Congreso constituyó una decisión inobjetable pues contribuye -sin dudas- a la transparencia en la actuación de los funcionarios. Pero la pertinaz negativa a reglar el secreto en el Poder Ejecutivo sólo puede ser vista como la voluntad política de mantenerlo. Exhibir leyes históricas o anodinas es una contribución insignificante a la transparencia.

El debate parlamentario dejó al descubierto esta situación que es una deuda en el proceso de consolidación del sistema democrático vigente. El Congreso ha suprimido el secreto legislativo pero ha dejado sin ataduras al secreto del Poder Ejecutivo. 
El futuro debate parlamentario debería dirigir sus preocupaciones hacia éste y consagrar -si se quiere- limitaciones al principio de publicidad, habilitando excepciones y la existencia de un secreto democrático. No hay una radical incompatibilidad o enfrentamiento entre la democracia y el secreto. Es más, el secreto en ocasiones puede ser defendido sobre la base de valores democráticos. La democracia -señalábamos con THOMPSON ${ }^{287}$ - requiere publicidad pero algunas políticas democráticas requieren secreto. La democracia también exige responsabilidad de los gobernantes pero para hacerla efectiva, los ciudadanos precisan conocer qué es lo que hacen. Este dilema puede, en alguna medida, ser resuelto aplicando tres técnicas: a) que los secretos sean temporarios, esto es, que no se conviertan en permanentes; b) que los secretos sean parciales y que no se conviertan en totales y c) que la decisión de conservar en secreto cierta resolución o política, sea hecha públicamente.

En distintos pasajes de este trabajo hemos subrayado que la publicidad de los actos de gobierno constituye un punto de debate actual y recurrente. Pero siempre hemos destacado que la publicidad, el secreto y la mentira estatales tienen una larga historia en el pensamiento político. Para no traicionar esa observación nos parece pertinente concluir con un texto de Bentham: "Una política secreta aleja de sí a veces algunos inconvenientes; pero no dudo de que ella a la larga los forma en mayor número que los impide; y que de dos gobiernos que caminan, el uno por las sendas del misterio, y el otro por la de la publicidad, el último tiene una fuerza, una valentía y reputación que le harán superior a todas las disimulaciones del otro" ${ }^{288}$.

\footnotetext{
${ }^{287}$ En "Democratic Secrecy", cit.

${ }^{288}$ An essay on political tactics en The Works of Jeremy Bentham Published Under the Superintendence of his Executor John Bowring, Edinburgh, Simpkin, Marshall and Co., 1843 (edición facsimilar), en capítulo II, \&1, p. 311.
} 


\section{BIBLIOGRAFÍA}

Alberd, Juan Bautista: Derecho público provincial, Buenos Aires, Talleres Gráficos Argentinos de L. J. Rosso, 1928.

AlBERDI, Juan Bautista: Fragmento preliminar al estudio del derecho, Buenos Aires, Biblos, 1984.

ALLIER MONTAÑO, Eugenia y CRENZEL, Emilio (Coordinadores): Las luchas por la memoria en América Latina. Historia reciente y memoria política, México, UNAM, Instituto de Investigaciones Sociales, 2015.

Ammirato, Aurelio L., Scheibler, Guillermo M. y TríPOLI, Pablo: "Ley 104 de acceso a la información de la Ciudad Autónoma de Buenos Aires", La Ley 2003-F-294.

ARENDT, Hannah: ¿Qué es política?, trad. Rosa SALA CARBÓ, Barcelona, Paidós, 1997.

ARENDT, Hannah: The Portable Hannah Arendt, New York, Penguin Books, 2000.

ARENDT, Hannah: La condición humana, trad. Ramón GIL NovALES, Buenos Aires, Paidós, 2009.

ARISTÓTEles: Retórica, trad. de Quintín Racionero, Madrid, Gredos, 2000.

ARRABAL DE JAMENSON, Myriam: Había una vez un tren. Sesenta años del ferrocarril en San Juan. 1887-1947, San Juan, Editorial EFFHA, 2010.

BASTERRA, Marcela I.: El derecho fundamental de acceso a la información pública, LexisNexis, Buenos Aires, 2006.

BASTERRA, Marcela I.: "Un nuevo aporte al desarrollo del derecho de acceso a la información pública. El fallo 'Morales v. Estado Nacional'”, Jurisprudencia Argentina 2008-II-540.

BASTERRA, Marcela I.: “Alcance de la legitimación -pasiva y activa- en un caso de acceso a la información pública en el ámbito municipal", La Ley 2007-A-98.

BASTERRA, Marcela: "Las leyes secretas en Argentina. Su inconstitucionalidad", La Ley 2006-D-1158.

BAYLeY, Paul (Ed.): Cross-Cultural Perspectives on Parliamentart Discourse, Amsterdam, Benjamins, 2004.

BENTHAM, Jeremy: The book of fallacies: from Unfinished Papers from Jeremy Bentham, London, John and H.L. Hunt, 1824.

BENTHAM, Jeremy: An essay on political tactics en The Works of Jeremy Bentham Published Under the Superintendence of his Executor John Bowring, Edinburgh, Simpkin, Marshall and Co., 1843 (edición facsimilar).

BENTHAM, Jeremy: Tratado de los sofismas políticos, trad. Francisco AYALA, Buenos Aires, Leviatán, 1986.

BIANCHI, Alberto A.: "El hábeas data como medio de protección del derecho a la información objetiva en un valioso fallo de la Corte Suprema", La Ley 1998-F297.

BIDART CAmpos, Germán J.: Manual de Derecho Constitucional Argentino, tercera edición, Ediar, Buenos Aires, 1974.

BIELSA, Rafael: Derecho constitucional, Depalma, Buenos Aires, 1959.

BITONTE, María Elena y DUMm, Zelma: "El discurso parlamentario ¿diálogo en la torre de Babel?", en MARAFIOTI, Roberto (editor), Parlamentos. Teoría de la argumentación y debate parlamentario, Biblos, Buenos Aires, 2007, p. 169. 
Blas ARROYO, José Luis: "No diga chorradas: La descortesía en el debate político cara a cara. Una aproximación pragma-variacionista" en "Oralia" $N^{\circ} 4$ (2001), p. 9.

BoвBı, Norberto: "Democracia y Secreto", publicado en el libro Norberto Bobbio: el filósofo y la política (Antología), traducción de José Fernández Santillán y Ariella Aureli, Fondo de Cultura Económica, México, 1996.

BobBIO, Norberto: El futuro de la democracia, traducción de José F. Fernández Santillán, tercera edición, Fondo de Cultura Económica, México, 2005.

BoBBio, Norberto: Estado, gobierno y sociedad. Para una teoría general de la política, traducción de José F. Fernández Santillán, México, Fondo de Cultura Económica, 2005.

BoHOSLAVSKY, Juan Pablo: ¿Usted también, doctor?: Complicidad de jueces, fiscales y abogados durante la dictadura, Buenos Aires, Siglo Veintiuno Editores, 2015.

BONNET, Alberto: La hegemonía menemista. El neoconservadurismo en Argentina, 1989-2001, Buenos Aires, Prometeo, 2007.

BoK, Sissela: Lying. Moral choice in public and private life, New York, Vintage Books, 1979.

BRANDEIS, Louis D., "What publicity can do" en "Harper's Weekly" (New York) del 20-12-1913.

BREYer, Stephen, Stewart, Richard B., Sunstein, Cass R. y Spitzer, Matthew L.: Administrative Law and Regulatory Policy. Problems, Text, and Cases, cuarta edición, Aspen Law\&Business, New York, 1999.

CAPPELLETTI, Mauro: "El derecho comparado: método y finalidades (Una propuesta metodológica)", en Dimensiones de la Justicia en el Mundo Contemporáneo (Cuatro estudios de derecho comparado), traducción de Héctor Fix Fierro, Porrúa, México, 1993, p. 13.

CARBONELL, Miguel: El régimen constitucional de la transparencia, Universidad Nacional Autónoma de México, México, 2008.

CARRAnZA TORRes, Luis R. y PALAZZI, Pablo A.: "Derecho de acceso a la información pública y derecho de acceso a la información privada (hábeas data): Semejanzas y diferencias", Jurisprudencia Argentina 2003-IV-68.

CATALÁN GonZÁleZ, Miguel: "Genealogía de la noble mentira", Amnis. Revue de Civilisation Contemporaine de l'Université de Bretagne Occidentale, 2004, vol. IV, pp. 257-273.

CEPPI, Natalia: "La temática energética en las relaciones entre Argentina y Bolivia. Acuerdos y contrariedades por el gas natural", en "Foro Internacional" (El Colegio de México), vol. L, No 1, p. 5.

CHARTIER, Roger: "Lo privado y lo público Construcción histórica de una dicotomía" en "Co-herencia: Revista de Humanidades", Año 2007, vol. 4 Nº 7.

CHOMSKY, Noam: Necessary Illusions Thought Control in Democratic Societies, London, Pluto Press, 1989.

Cisneros, Isidro H.: Norberto Bobbio: de la razón de Estado al gobierno democrático, México, Instituto Electoral y de Participación Ciudadana del Estado de Jalisco, 2014.

CONDORCET, Marqués de: ¿Es conveniente engañar al pueblo?, trad. de Javier DE LUCAS, Madrid, Sequitur, 2009.

CONTRERAS, Pablo: "Transparencia y leyes secretas en Chile", "Estudios Constitucionales" (Chile), Año 8, № 2, 2010, p. 87. 
CROCKER, Lester Gilbert: "The Problem of Truth and Falsehood in the Age of Enlightenment", Journal of the History of Ideas, volumen 14, $\mathrm{N}^{\circ} 4$, p. 575.

D’AgostinI, Franca: Mentira, trad. Ana Miravalles, Buenos Aires, Adriana Hidalgo Editora, 2014.

D'ANTONIO, Débora y EIDELMAN, Ariel: "El fuero antisubversivo y los consejos de guerra contra civiles en la Argentina de los años 70" en "Estudios Interdisciplinarios de America Latina y el Caribe" (Tel Aviv), Año 2016, vol. 27 p. 7.

DAHL, Robert: On Democracy, Yale University Press, New Haven-London, 2000.

DAHL, Robert A.: A Preface to Democratic Theory, Chicago, The University of Chicago Press, 2006.

DAVID, René y JAUFFRET-SPINOSI, Camilla: Les grands systèmes de droit contemporains, $10^{\circ}$ edición, Dalloz, Paris, 1992.

DE LUCAS, Javier: "Anotaciones sobre el principio kantiano de publicidad", en “Diánoia”, volumen 33, n 33 (1987), p. 131.

DE LUCAS, Javier: "Sobre el origen de la justificación paternalista del poder en la antigüedad clásica”, Doxa, № 5 (1988), p. 243.

DE LUCAS, Javier: "Secretos de Estado", Revista del Instituto Bartolomé de las Casas, Año No 4, N 7, 1999, p. 35.

DERRIDÁ, Jacques: Historia de la mentira. Prolegómenos, Buenos Aires, EUFyL, 2015.

Donaldson, Peter S.: Machiavelli and Mystery of State, Cambridge, Cambridge University Press, 1992.

Federico El Grande: Antimaquiavelo o Refutación del Príncipe de Maquiavelo, trad. Roberto R. ARAMAYO, Madrid, Centro de Estudios Constitucionales, 1995.

FERNÁNDEZ GARCíA, Eusebio: Entre la Razón de Estado y el Estado de Derecho, Madrid, Dykinson, 1997.

FERNÁNDEZ RAMOS, Severiano: "La experiencia europea en materia de transparencia administrativa y acceso a la información", en la obra coordinada por CONCHA CANTÚ, Hugo A., LÓPEZ-AYLLÓN, Sergio y TACHER EPELSTEIN, Lucy: Transparentar al Estado: la experiencia mexicana de acceso a la información, Universidad Autónoma de México, México, 2004, p. 261.

FERRAJOLI, Luigi: "Pasado y futuro del estado de derecho", en "Revista Internacional de Filosofía Política”, № 17 (2001), p. 31.

FoucAult, Michel: Microfísica del poder, trad. de Julia VARELA y Fernando ÁlvAREZ-URíA, Madrid, Ediciones de La Piqueta, 1980.

FoucAult, Michel: Defender la sociedad. Curso en el Collège de France (19751976), Buenos Aires, Fondo de Cultura Económica, 2001.

FOUCAULT, Michel: Historia de la sexualidad, trad. de Ulises GuIÑAZÚ, 30ma ed., Buenos Aires, Siglo XXI Editores, 2005.

FuCHS, Meredith: "Judging Secrets: the Role Courts Should Play in Preventing Unnecessary Secrecy”, Administrative Law Review, n0 58, p. 131.

García Mansilla, Manuel José-Ramírez Calvo, Ricardo: Las fuentes de la Constitución Nacional, Buenos Aires, LexisNexis, 2006.

GARGARELLA, Roberto: "El nuevo constitucionalismo latinoamericano", en "Estudios Sociales" No 48 (primer semestre 2015), p. 169.

GARZÓN VALDÉZ, Ernesto: "Privacidad y publicidad" en "Doxa" No 21, vol. 1 (1998), p. 223. 
Gellhorn, Walter-BYSe, Clark: Administrative Law. Cases and Comments, novena edición, The Foundation Press, Westbury, New York, 1995.

GHIRARDI, Olsen A.: La filosofía en Alberdi, Córdoba, Academia Nacional de Derecho y Ciencias Sociales de Córdoba, 1993.

GIALDINO, Rolando E.: "Control de constitucionalidad y de convencionalidad de oficio. Aportes del Derecho Internacional de los derechos humanos", La Ley 2008-C-1295.

GIRAUD, Claude: Acerca del secreto. Contribución a una sociología de la autoridad y del compromiso, traducción de Roberto Marafioti, Biblos, Buenos Aires, 2007.

GonZÁLEZ, Joaquín V.: Manual de la Constitución Argentina, vigésima edición, Ángel Estrada y Cía., Buenos Aires, s/d.

GonZÁlez CALDERón, Juan A.: Curso de Derecho Constitucional, sexta edición, Depalma, Buenos Aires, 1988.

GONZÁLEZ DE ZÁRATE LORENTE, Roberto: "El obstruccionismo parlamentario" en "Asamblea: revista parlamentaria de la Asamblea de Madrid" № 27 (2012), p. 183.

GoRDILlo, Agustín A.: Tratado de Derecho Administrativo, Macchi, Buenos Aires, 1980.

GORDILLO, Agustín: "Un corte transversal al derecho administrativo: la Convención Interamericana contra la Corrupción", La Ley 1997-E-1091.

GRÜNER, Eduardo: "La astucia del león y la fuerza del zorro. Maquiavelo, entre la verdad de la política y la política de la verdad" en BoRón, Atilio A. (Comp.), La filosofía política clásica. De la Antigüedad al Renacimiento, Buenos Aires, Clacso-Eudeba, 1999, capítulo VIII.

HÄBERLE, Peter: "Avances constitucionales en Europa Oriental desde el punto de vista de la jurisprudencia y de la teoría constitucional" en "Pensamiento Constitucional" (Perú), vol. 2, № 2 (1995), p. 141.

HABERMAS, Jürgen: Historia y crítica de la opinión pública, trad. Antoni Domènech, 2da ed., Barcelona, GG MassMedia, 1981.

HABERMAS, Jürgen: "Tres modelos de democracia: sobre el concepto de una política deliberativa", en "Polis: revista académica de la Universidad Bolivariana", No 10 (2005).

HERRANZ GonZÁleZ, Roberto: "Georg Simmel y la sociología económica: el mercado, las formas sociales y el análisis estratégico", "Papers: Revista de Sociologia", 2008, N 87, p. 269-286.

HINS, Wouter- VoORHOOF, Dirk: "Access to State-Held Information as a Fundamental Right under the European Convention on Human Rights", European Constitutional Law Review, volumen 3, n 1, p. 114 (2007).

IAZZETTA, Osvaldo M., "La democracia y los vaivenes de lo público-estatal", "Revista Sociedad Argentina de Análisis Político (SAAP)". Vol 1, № 2. pgs. 377408 (2003).

ILIE, Cornelia: "Insulting as (un)parliamentary practice in the British and Swedish parliaments. A rhetorical approach" en BAYLEY, Paul (Editor), CrossCultural Perspectives on Parliamentary Discourse, Amsterdam, Benjamins, 2004, p. 45.

ILIE, Cornelia: "Parliamentary Discourses", en Keith BRoWN (ed.) Encyclopedia of Language and Linguistics 2nd Edition, Vol. 9, 188-197 (2006) Oxford, Elsevier. 
JoLY, Maurice: Diálogo en el infierno entre Maquiavelo y Montesquieu, trad. de Luis Rutiaga, México, Grupo Editorial Tomo, 2009.

JUAN LIMA, Fernando E.: “Las 'leyes secretas'”, La Ley 2005-C-695.

JUAN LIMA, Fernando E.: "'Leyes secretas': Continúa el sigilo", La Ley 2006-E74.

KANT, Immanuel: La paz perpetua, traducción de F. Rivera Pastor, novena edición, Espasa Calpe, Madrid, 1997.

KANT, Immanuel: El conflicto de las facultades, trad. de Elsa TABERNIG, Buenos Aires, Losada, 2004.

KELSEN, Hans: Esencia y valor de la democracia, traducción de Rafael Luengo Tapia y Luis Legaz Lacambra Punto Omega, Guadarrama, Madrid, 1977.

KOSELLECK, Reinhart: Critique and Crisis: Enlightenment and the Pathogenesis of Modern Society, Cambridge, Massachusetts, The MIT Press, 1988.

KosELLECK, Reinhart y GADAMER, Hans-Georg: Historia y hermenéutica, trad. Faustino OncINA, Barcelona, Paidós, 1997.

KOYRÉ, Alexandre: Reflexiones sobre la mentira, Buenos Aires, Leviatán, 2004 (edición bilingüe).

KUTLER, Stanley I.: Watergate: a brief history with documents, 2da. ed., New York, Wiley-Blackwell, 2010.

LABOURDETTE, Sergio: "Secreto y poder en la vida social", en "Orientación y Sociedad", vol. 5, enero/diciembre de 2005 (La Plata), p 59.

LACLAU, Martín: "Las influencias filosóficas en el pensamiento de Juan Bautista Alberdi" en "Revista de historia del derecho", Buenos Aires, N 41, p. 139-161 (junio- 2011).

LAVALLE COBO, Dolores: "Un nuevo avance jurisprudencial en derecho de acceso a la información pública", La Ley 2005-D-848.

LAVALLE COBO, Dolores: "El derecho de acceso a la información pública: El presupuesto del Estado nacional”, La Ley ejemplar del 2-9-2008.

LINARES QUINTANA, Segundo V.: "Joaquín V. González, el místico de la Constitución", en "Revista de estudios políticos" (Madrid) No 137 (1964), p. 181. LoCKE, John: Two Treatises of Government, Cambridge, Cambridge University Press, 2003.

LÓPEZ AYLLÓN, Sergio y POSADAS, Alejandro: "Las pruebas de daño e interés público en materia de acceso a la información pública. Una perspectiva comparada", Derecho Comparado de la Información, nº 9 (2007), p. 21.

MaingueneaU, Dominique: "Problemas de ethos" en "Pratiques" No 113/114 (junio de 2002), pp. 55-67 (traducción de M. Eugenia ConTURSI).

MARICHAL SALINAS, Carlos: Historia mínima de la deuda externa de latinoamérica, 1820-2010, México, El Colegio de México, 2014.

MaquiAvelo, Nicolás: El Príncipe, traducción de Eli LeONETTI JUNGL, Barcelona, Espasa-Calpe, 1995.

MAQUIAVELO, Nicolás: Discurso sobre la primera década de Tito Livio, traducción de Ana Martínez Arancón, Alianza Editorial, Madrid, 1996.

MARAFIOTI, Roberto: "Discurso parlamentario: entre la política y la argumentación", en MARAFIOTI, Roberto (editor), Parlamentos. Teoría de la argumentación y debate parlamentario, Biblos, Buenos Aires, 2007, p. 93.

Mateucci, Nicola: voz Opinión pública en Norberto, MatTEuccl, Nicola y PASquINo, Gianfranco, Diccionario de Política, México, Siglo XXI, 2008, tomo II, p. 1076. 
MeINECKE, Friedrich: The Doctrine of Raison d'Etat and Its Place in Modern History. Machiavellism, trad. Douglas Scott, New Brunswick-London, Transaction Publishers, 1998.

MENDEL, Toby: Freedom of Information: A Comparative Legal Survey, segunda edición, UNESCO, Paris, 2008.

MÉnDEZ, Luis M. y PalAZZI, Pablo A.: "Un caso de derecho de acceso a la información pública", El Derecho 180-426.

MORENO, Mariano: Sobre las miras del Congreso y Constitución del Estado, con otros escritos políticos, Buenos Aires, Lambda, 1929.

MuZILA, Lindy- Morales, Michelle-Mathias, Marianne-Berger, Tammar: Les Profiteurs Incriminer l'enrichissement illicite pour combattre la corruption, Washington, World Bank, 2014.

NAVARRO DíAZ, Luis R., Entre esferas públicas y ciudadanía. Las teorías de Arendt, Habermas y Mouffe aplicadas a la comunicación para el cambio social, Barranquilla, Ediciones Uninorte, 2010.

NAVARRO FloRIA, Pedro: "La nacionalización fallida de la Patagonia Norte, 1862-1904", en "Revista Quinto Sol" (Universidad Nacional de La Pampa), № 7 , p. 61.

Nino, Carlos S.: Fundamentos de derecho constitucional. Análisis filosófico, jurídico y politológico de la práctica constitucional, Astrea, Buenos Aires, 2000.

NISBET, Robert: La formación del pensamiento sociológico, traducción de Enrique MolinA DE VEDIA, segunda edición, Buenos Aires, Amorrortu, 2009.

NovARO, Marcos: Cables secretos, Edhasa, Buenos Aires, 2011.

O'DONNELL, Guillermo: "Acerca de varias 'accountabilities' y sus interrelaciones", en PeruzzotTI, Enrique y Catalina Smulovitz, Controlandola política. Ciudadanos y medios en las nuevas democracias latinoamericanas, Buenos Aires, Temas, 2000.

O'Donnell, Guillermo: Disonancias. Críticas democráticas a la democracia, Buenos Aires, Prometeo, 2007.

OPEN SOCIETY INSTITUTE: Transparencia \& Silencio. Encuesta sobre leyes y prácticas del acceso a la información en catorce países, Open Society Institute, New York, 2006.

OsZLAK, Oscar: "Estado abierto: hacia un nuevo paradigma de gestión pública", trabajo presentado en el panel "Gobierno Abierto en Iberoamérica: promesas y realizaciones", XVIII Congreso Internacional del CLAD, Montevideo, 2013.

Perelman, Ch.: La lógica jurídica y la nueva retórica, trad. Luis Diez-PICAZo, Madrid, Civitas, 1988.

Perelman, Ch.-Olbrechts-Tyteca, L.: The New Rhethoric. A treatise on Argumentation, trad. John WILKINSON-Purcell WEAVER, Notre Dame, University of Notre Dame, 2000.

PereYRA, Sebastián: Política y transparencia. La corrupción como problema público, Buenos Aires, Siglo XXI, 2013.

PERRITT JR., Henry H.: "Electronic Freedom of Information", Administrative Law Review, $\mathrm{n}^{\circ}$ 50, p. 391.

Pierce, JR., Richard J., Shapiro, Sidney A., Verkull, Paul R.: Administrative Law and Process, cuarta edición, Foundation Press, New York, 2004.

PISTONE, Sergio: voz Razón de Estado, en BobBio, Norberto, MATTEUCCI, Nicola y PAsquino, Gianfranco, Diccionario de Política, México, Siglo XXI, 2008, tomo II, p. 1337. 
Pittaluga Roberto: "La memoria según Trelew" en "Sociohistórica. Cuadernos del CISH", No 19/20, La Plata, Universidad Nacional de La Plata, p. 81.

PlATON: República, traducción de Antonio Camarero, Eudeba, Buenos Aires, 1968.

RABOtNIKof, Nora, El espacio público y la democracia moderna, México, Instituto Federal Electoral, 1997.

RABOTNIKOF, Nora: "Corrupción política: definiciones técnicas y sentidos sedimentados" en "Insomnia" № 10 (México), abril 1999, p. 25.

RABOTNIKOF, Nora: En busca de un lugar común. El espacio público en la teoría política contemporánea, México, Universidad Nacional Autónoma de México, 2005.

RABOTNIKOF, Nora: "Lo público hoy: lugares, lógicas y expectativas", "Iconos. Revista de Ciencias Sociales", № 32, 2008, p. 37/48.

RAMÓN-FERNÁNDEZ, Tomás: "De la banalidad a la incoherencia y la arbitrariedad. Una crónica sobre el proceso, al parecer imparable, de degradación de la ley", "El Cronista del Estado Social y Democrático de Derecho" Nº (2008), p. 46.

RISOLÍA, Marco Aurelio: "Publicidad de los actos de gobierno, ignorancia de la ley y leyes secretas", El Derecho 68-837.

RITZER, George: Teoría sociológica clásica, traducción de María Teresa CASAdo RodrígueZ, Madrid, McGraw-Hill, 1993.

RodRíguez VILLAFAÑE, Miguel Julio: "La transparencia en el Poder Judicial de Argentina”, en CABALlero JuÁREZ, José Antonio, GREgorio, Carlos G., POPKIN, Margaret y VILLANUEVA, Ernesto, El acceso a la información judicial en México y desde una visión comparada, Universidad Nacional Autónoma de México, México, 2005.

RodRiguez ZEPEDA, Jesús: Estado y transparencia: un paseo por la filosofía política, México, Instituto Nacional de Transparencia, Acceso a la Información y Protección de Datos Personales, Cuadernos de Transparencia, № 4.

ROMERO, José Luis: "Las ideas filosóficas de Moreno" en La experiencia argentina y otros ensayos, Buenos Aires, Editorial de Belgrano, 1980, p. 199.

ROMERO, José Luis: Las ideas políticas en la Argentina, Buenos Aires, Fondo de Cultura Económica, 1984.

Rose-ACKERMAN, Susan: La corrupción y los gobiernos. Causas, consecuencias y reforma, trad. de Alfonso ColodRón GómEZ, Buenos Aires, Siglo Veintuno Editores, 2001.

SABA, Roberto: "El derecho de la persona a acceder a la información en poder del gobierno", Derecho Comparado de la Información (México), № 3, enerojulio de 2004, p. 145.

SÁBATO, Hilda: Historia de la Argentina 1852-1890, Buenos Aires, Siglo Veintiuno, 2012.

SAGÜÉS, Néstor P.: Las leyes secretas. El sigilo legislativo en el derecho constitucional argentino, segunda edición, LexisNexis, Buenos Aires, 2005.

SAHUIS, Alejandro: Razón y espacio público: Arendt, Habermas y Rawls, México, Ediciones Coyoacán, 2002.

SAmpay, Arturo E.: Estudios de Derecho Público, Constitucional, de Gentes y Eclesiástico, Buenos Aires, Editorial Toaitéia, 1951.

SARRABAYRouSE OlIVEIRA, María José: "Familia judicial y dictaduras: la creación del fuero antisubversivo en la década del 70" en ÁGUILA, Gabriela, GARAÑo, Santiago y SCATIZZA, Pablo (Coordinadores), Represión estatal y violencia 
paraestatal en la historia reciente argentina, La Plata, Universidad Nacional de La Plata, Facultad de Humanidades y Ciencias de la Educación, 2016, p. 269. SARTORI, Giovanni: ¿Qué es la democracia?, trad. de González Rodríguez y Pestellini Laparelli Salomon, Taurus, Buenos Aires, 2003.

Schmidt-Liermann, Cornelia, Rovere, Marta B. y Lavalle Cobo, Dolores: Periodismo y acceso a la información pública, Konrad Adenauer Stiftung, Buenos Aires, 2003.

SCHUMPETER, Joseph A.: Capitalism, Socialism and Democracy, Routledge, London-New York, 2003.

SCHWARTZ, Bernard: Administrative Law, cuarta edición, Little, Brown and Company, Boston-New York-Toronto-London, 1994.

SIMMEL, Georg: "The Sociology of Secrecy and of Secret Societies", publicado en la revista "American Journal of Sociology", volumen 11, $\mathrm{n}^{\circ} 4$ (Enero, 1906), p. 441-498.

SIMMEL, Georg: The Sociology of Georg Simmel, Illinois, The Free Press, 1950.

SIMMEL, Georg: Cuestiones fundamentales de sociología, traducción de Ángela ACKERMANN PILÁRI, Barcelona, Gedisa, 2002.

Strauss, Leo-Cropsey, Joseph, History of Political Philosophy, 3era ed., Chicago-London, The University of Chicago Press, 1987.

StRAUSS, Peter L.: An Introduction to Administrative Justice in the United States, Carolina Academic Press, North Carolina, 1989.

SUDRE, Frédéric: Droit européen et international des droits de l'homme, octava edición, Presses Universitaires de France, Paris, 2006.

SWIFT, Jonathan: El arte de la mentira política, Sequitur, Madrid, 2006.

TÁcito Cornelio: Anales, trad. de Carlos Coloma, 4ta ed., México, Porrúa, 2005. TAU AnzoAtegui, Víctor-MARTIRE, Eduardo: Manual de historia de las instituciones argentinas, 4ta edición, Buenos Aires, Macchi, 1975.

TERÁN, Oscar: Historia de las ideas en la Argentina. Diez lecciones iniciales, 1810-1980, Buenos Aires, Siglo XXI, 2008.

THEOHARIS, Athan G.: A Culture of Secrecy. The Government Versus the People's Right to Know, University Press of Kansas, Kansas, 1998.

THOMPSON, Dennis F.: "Democratic Secrecy", en "Political Science Quarterly", vol. 114, n² 2 (1999), p. 181.

ThOMPSON, Dennis F.: Restoring Responsibility Ethics in Government, Business, and Healthcare, Cambridge University Press, Cambridge-New York, 2005.

TIERSKY, Ronald: François Mitterrand: A Very French President, Rowman \& Littlefield, New York, 2003.

TRAVIESO, Florencio: "El derecho de acceso a la información pública. Principios y fundamentos en un reciente fallo", El Derecho 197-297.

TSAKONA, Villy- Popa, Diana Elena: "Humour in politics and the politics of humour. An introduction" en TSAKONA, Villy- Popa, Diana Elena (Editores), Studies in Political Humour. In between political critique and public entertainment, Amsterdam-Philadelphia, John Benjamins Publishing Company, 2011 , p. 1.

UGARTE, José Manuel: El derecho de acceso a la información. Su vigencia en Argentina, con un panorama del derecho comparado, La Isla de la Luna, Buenos Aires, 2007. 
UHL, Kristen E.: "The Freedom of Information Act Post-9/11: Balancing the Public's Right to Know, Critical Infrastructure Protection, and Homeland Security" en "American University Law Review", vol. 53, № 1 (2003), p. 261.

Vallefín, Carlos A.: El acceso a la información pública. Una introducción, Ad Hoc, Buenos Aires, 2009.

VAN DIJK, Teun A.:"What is Political Discourse Analysis?", Key-note address Congress Political Linguistics. Antwerp, 7-9 -December 1995, en Jan BlommAert \& Chris BULCAEN (Eds.), Political linguistics.(pp. 11-52). Amsterdam: Benjamins, 1997.

VAN DIJK, Teun A.: "On the analysis of parliamentary debates on immigration" en Reisigl M.-Wodak, Ruth (Eds.), The semiotics of racism. Approaches to critical discourse analysis, Vienna, Passagen Verlag, 2000, p. 85.

VAN DIJK, Teun A.: "Text and context of parliamentary debates", en Paul BAYLEY (Ed.), Cross-Cultural Perspectives on Parliamentart Discourse. (pp. 339- 372). Amsterdam: Benjamins, 2004.

VAN DIJK, Teun A.: "La contextualización del discurso parlamentario: Aznar, Iraq y la pragmática del mentir" en CORTÉs RodRÍGUEZ, Luis María (coordinador), Discurso y oralidad: homenaje al profesor José Jesús de Bustos Tovar, Madrid, Arco Libros, 2007, volumen 1, p. 137.

VAN DIJK, Teun A.:"Racism and the Press in Spain", en José Luis BLAS, Manuela Casanova, Mónica Velando \& Javier Vellón (Eds.), Discurso y Sociedad II. Nuevas contribuciones al estudio de la lengua en un contexto social. (pp. 5999). Castelló de la Plana, Universitat Jaume I, 2008.

VERÓN, Eliseo: "La palabra adversativa", en El discurso político. Lenguajes y acontecimientos, Buenos Aires, Hachette, 1987, p. 1.

VILLANUEVA, Ernesto: Derecho de acceso a la información en el mundo, Miguel Ángel Porrúa-Universidad Nacional Autónoma de México, México, 2006.

VILLANUEVA, Ernesto: "Derecho de acceso a la información en el Poder Judicial. Una aproximación al caso mexicano desde la perspectiva comparada", en Caballero JuÁrez, José Antonio, Gregorio, Carlos G., PopkIn, Margaret y VILLANUEVA, Ernesto, El acceso a la información judicial en México y desde una visión comparada, Universidad Nacional Autónoma de México, México, 2005.

Weber, Max: Economía y sociedad, traducción de Medina Echevarria, Roura Parella, Ímaz, García Maynez y Ferrater Mora, segunda edición, Fondo de Cultura Económica, México, 1992.

WISE, David: The Politics of Lying, New York, Random House, 1973.

ZAFFARONI, Eugenio Raúl: "Alberdi y la vigencia de la Constitución de 1853" en QUATTROCHI-WOISSON, Diana (Directora) Juan Bautista Alberdi y la Independencia argentina. La fuerza del pensamiento y de la escritura, Quilmes, Universidad de Quilmes, 2012, p. 59.

Zarka, Yves C.: voz Raison d'Etat en RaYnaud, Philippe y RIALS, Stéphane, Dictionnaire de philosophie politique, 3era. edición, Paris, Quadrige-Puf, 2005, p. 612.

ZAPATA, Victoria, La revolución argentina (1966-1973) en SIMONOFF, Alejandro (Compilador), La Argentina y el mundo frente al bicentenario de la Revolución de Mayo : las relaciones exteriores argentinas desde la secesión de España hasta la actualidad, La Plata, Universidad Nacional de La Plata, 2010, p. 257. 
